INTER NATIONAL MONETARY FUND
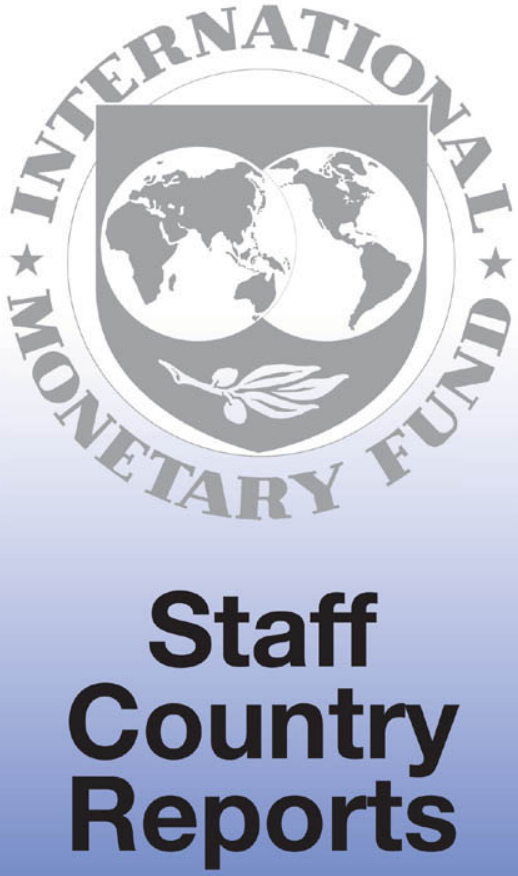


\title{
Fiji: 2009 Article IV Consultation-Staff Report; Public Information Notice on the Executive Board Discussion; and Statement by the Executive Director for Fiji
}

Under Article IV of the IMF's Articles of Agreement, the IMF holds bilateral discussions with members, usually every year. In the context of the 2009 Article IV consultation with Fiji, the following documents have been released and are included in this package:

- $\quad$ The staff report for the 2009 Article IV consultation, prepared by a staff team of the IMF, following discussions that ended on November 24, 2009, with the officials of Fiji on economic developments and policies. Based on information available at the time of these discussions, the staff report was completed on December 22, 2009. The views expressed in the staff report are those of the staff team and do not necessarily reflect the views of the Executive Board of the IMF.

- $\quad$ A Public Information Notice (PIN) summarizing the views of the Executive Board as expressed during its January 11, 2010 discussion of the staff report that concluded the Article IV consultation.

- $\quad$ A statement by the Executive Director for Fiji.

The policy of publication of staff reports and other documents allows for the deletion of market-sensitive information.

\author{
Copies of this report are available to the public from \\ International Monetary Fund $\bullet$ Publication Services \\ $70019^{\text {th }}$ Street, N.W. $\bullet$ Washington, D.C. 20431 \\ Telephone: (202) 623-7430 • Telefax: (202) 623-7201 \\ E-mail: publications@imf.org Internet: http://www.imf.org
}

\section{International Monetary Fund Washington, D.C.}


This page intentionally left blank

CInternational Monetary Fund. Not for Redistribution 


\title{
INTERNATIONAL MONETARY FUND
}

\section{FIJI}

\author{
Staff Report for the 2009 Article IV Consultation \\ Prepared by the Staff Representatives for the 2009 Consultation with Fiji \\ (In consultation with other departments) \\ Approved by James Gordon and Aasim Husain
}

December 22, 2009

- Discussions: November 10-24, 2009, with Prime Minister and Finance Minister Bainimarama, Reserve Bank Governor Reddy, Acting Minister of Finance SayedKhaiyum, Finance Secretary Prasad, other senior officials, representatives from the private sector and donors.

- Team: Messrs. Brooks (head), Dunn, Morales (all APD), Ms. Takahashi (FAD), and Ms. Saeju (MCM). Ms. Vongpradhip and Mr. Toh (OED) participated in the discussions. Ms. Ferguson (AsDB), Ms. Horscroft (World Bank) and Mr. Cuddihy (World Bank consultant) joined part of the mission.

- Focus of mission: Policies to maintain macroeconomic stability, address balance of payments financing gaps, and raise growth over the medium term.

- Past surveillance: The 2004 Article IV consultation was completed on August 23, 2004 (http://www.imf.org/external/np/sec/pn/2004/pn04102.htm). The key issue was the pace of fiscal consolidation, with Directors divided between the authorities' approach and the staff's suggested acceleration.

- Delay of Article IV: The 2006 Article IV was delayed by a military coup (Fiji was on a 24-month cycle). The 2007 Surveillance Decision contributed to a further delay, as the authorities discussed staff concerns over the Fijian dollar being significantly overvalued.

- The exchange rate is pegged to a basket. Some controls constitute exchange restrictions subject to Fund approval under Article VIII.

- Outreach: Staff presented a seminar on the regional outlook to the Economics Association of Fiji and held a press conference at the conclusion of the mission. 
Executive Summary

I. Background

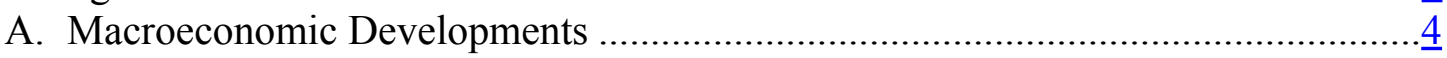

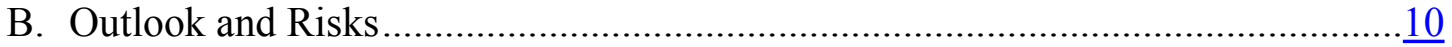

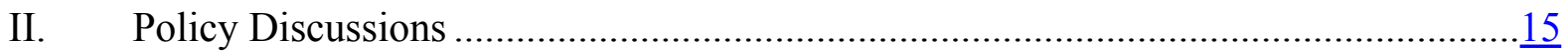

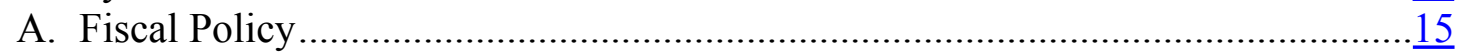

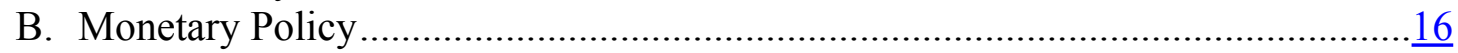

C. Financial Sector Policy …………………………......................................

D. External Vulnerabilities and Financing Gap ....................................................

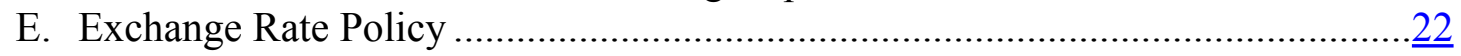

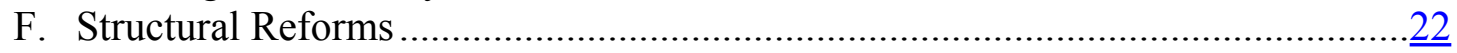

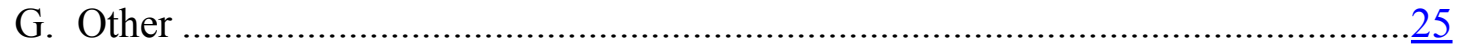

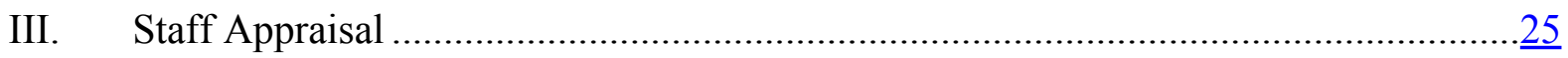

Boxes

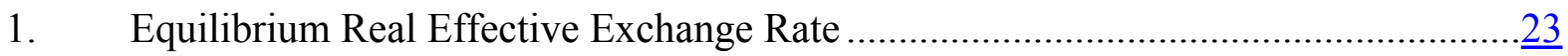

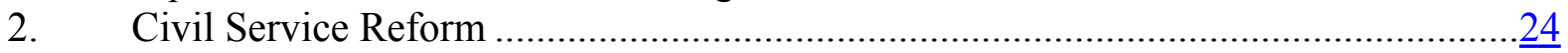

\section{Figures}

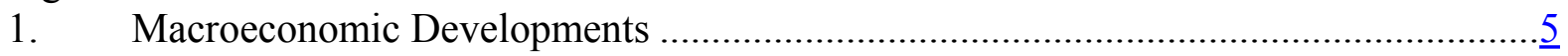

2. Impact of Global Crisis on Pacific Island Countries ……………………………........

3. Exchange Rate and Inflation Developments........................................................

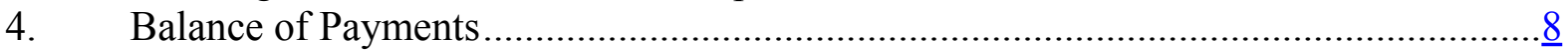

5. Tourism Developments Affecting Fiji ................................................................

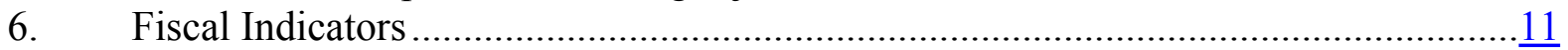

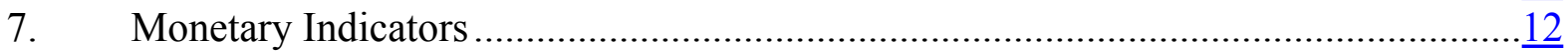

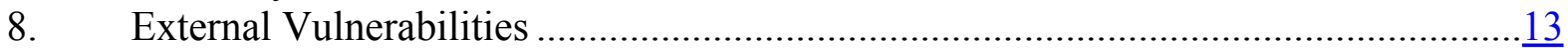

9. Financial Soundness Indicators........................................................................

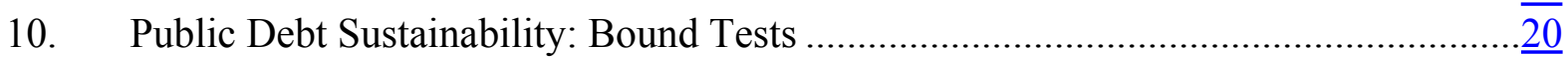

11. External Debt Sustainability: Bound Tests ............................................................

Tables

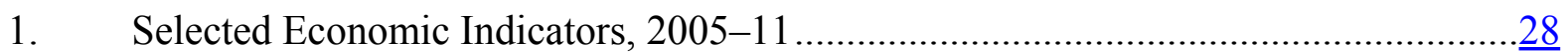

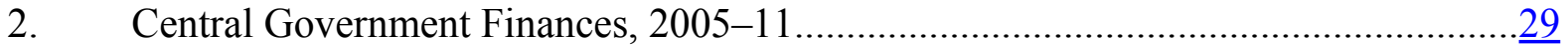

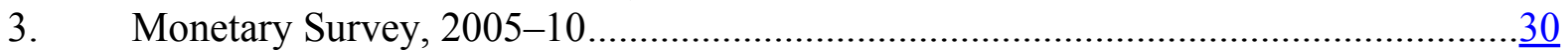

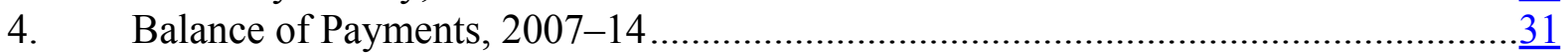

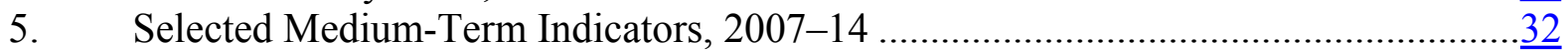

6. Status of Key 2004 Fiscal ROSC Recommendations .................................................

7. Status of Key FAD Recommendations on Tax Policy and Administration ...................

8. Status of Key 2006 FSAP Recommendations …………………............................ 


\section{EXECUTIVE SUMMARY}

Economic growth in Fiji has been sluggish in recent years due to political developments, delays in structural reforms, and worsening terms of trade. The economy is expected to contract by $2 \frac{1}{2}$ percent in 2009 , as the global crisis reduced exports, tourism and remittances. In addition, floods damaged crops and tourist infrastructure in early 2009. As a result, foreign reserves fell to low levels, prompting a devaluation of the currency by 20 percent in April 2009. GDP growth of 2 percent is likely in 2010, driven by a rebound in tourism, the global recovery, and rebuilding after the floods.

Fiji, however, faces considerable downside risks. Increased liquidity in the banking system poses risks of inflation and loss of competitiveness, while high government debt and contingent liabilities (together 70 percent of GDP) raise concerns about fiscal sustainability. The growth outlook remains highly uncertain due to political developments, volatility of commodity prices, the risk of natural disasters, and the complex structural reform agenda.

\section{Staff recommended tighter fiscal policy to safeguard macroeconomic stability and} ensure sustainability. Staff advised a reduction in the budget deficit to about 2 percent of GDP in 2010 - excluding the cost of civil service reform - with further consolidation over the medium-term. The authorities agreed on the need for medium-term consolidation, but at a gradual pace. The 2010 budget targets a small increase in the deficit to $3 \frac{1}{2} 2$ percent of GDP, with consolidation planned for 2011 and beyond.

Staff and the authorities agreed that monetary policy should be tightened to ensure inflation returns to low levels and protect foreign exchange reserves. The Reserve Bank of Fiji (RBF) recently increased banks' required reserves and removed ceilings on banks' lending rates and spreads. The RBF is considering further steps to tighten liquidity, but did not see the need for a substantial increase in interest rates given the fragile economic outlook.

The authorities are evaluating the possibility of a more flexible exchange rate arrangement. Staff believe that a more flexible exchange rate would help absorb external shocks and protect Fiji's reserve position.

A comprehensive package of structural reforms is being prepared by the authorities to spur growth and create jobs. This includes reforms to the civil service, public enterprises, public pension fund, and land-lease system - together with price liberalization. Staff noted the importance of well designed reforms to lift potential growth.

The authorities expressed interest in a Fund program to support structural reform and help fill a financing gap of more than US\$500 million projected for 2010-12. A program could also catalyze donor support. The authorities have not made a formal request at this stage and staff will follow up with them in early 2010. 


\section{BACKGROUND}

\section{A. Macroeconomic Developments}

1. Growth has been sluggish in recent years because of little progress on economic reforms and worsening terms of trade (Figure 1, Table 1). Key land and sugar sector reforms have been delayed, contributing to a decline in sugar output. The current account deficit widened from 1 1 $\frac{1}{2}$ percent in 2000 to 18 percent of GDP in 2008, as the terms of trade worsened by more than 15 percent, because of lower export prices for sugar and higher oil prices. The real effective exchange rate appreciated by 10 percent over the same period and foreign exchange reserves fell to US\$300 million in early 2009, less than two months of imports. As a result of slow growth, the unemployment rate rose to $81 / 2$ percent, and would have been higher if not for an increase in emigration.

\section{Economic performance has also been affected by political developments that} have strained Fiji's international relations and hurt business confidence. Tensions between indigenous Fijians and the local Indian community led to coups in 1987 and 2000, while political differences within the indigenous Fijian community contributed to a further coup in 2006. In April 2009, President Iloilo abrogated the constitution after courts ruled that the removal of the government in 2006 was illegal. After being reappointed as Prime Minister, Army Chief Commodore Bainimarama announced new elections for 2014. Political developments resulted in Fiji being suspended from the Commonwealth and the Pacific Forum and strained relations with some donors.

3. Fiji's economy is expected to have contracted in 2009, reflecting the adverse impact of the global crisis on exports, tourism, and workers' remittances. Staff expects real GDP to decline by $2 \frac{1}{2}$ percent in 2009 and exports to fall by 30 percent, in line with other Pacific Island countries (Figure 2). On the positive side, lower commodity prices have reduced the import bill.

4. The economy was also hit by flooding in January 2009 that damaged tourism, crops, and infrastructure. A request for Emergency Natural Disaster Assistance was issued to the IMF Executive Board in April, but was later withdrawn because of political events.

5. RBF devalued the currency by 20 percent in April 2009 to stem the loss of foreign exchange reserves. The RBF also intensified exchange controls, including on dividend payments to foreign companies. Following the devaluation, weak economic activity and lower commodity prices helped contain inflation (Figure 3 ).

\section{The devaluation helped reverse the sharp decline in foreign exchange reserves.} Reserves doubled between April and November 2009, to reach US\$593 million, almost four months of imports. About half the increase came from a pickup in remittances and an improvement in the trade balance (Figure 4). Most of the remaining increase was due to the SDR allocation (US\$93 million) and repatriation of foreign assets of the Fiji National 
Figure 1. Fiji: Macroeconomic Developments

Real GDP per capita has remained flat for more than a decade, unlike in comparable countries.

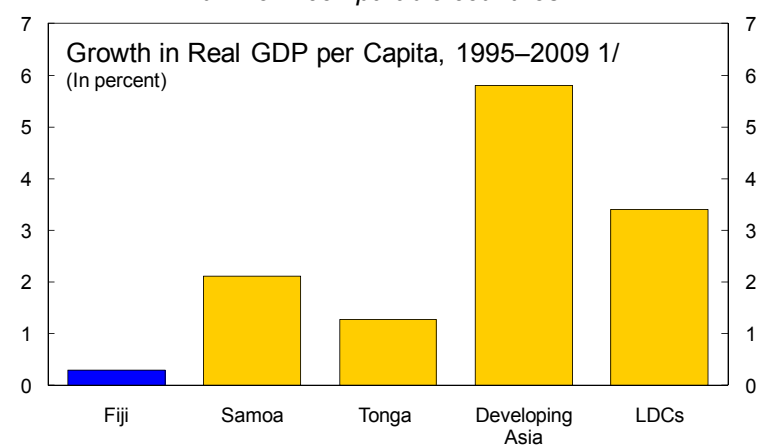

Sources: IMF, World Economic Outlook database; and Fund staff calculations. $1 /$ Geometric average.

Investment rose in 2003-06 but declined after the 2006 coup.

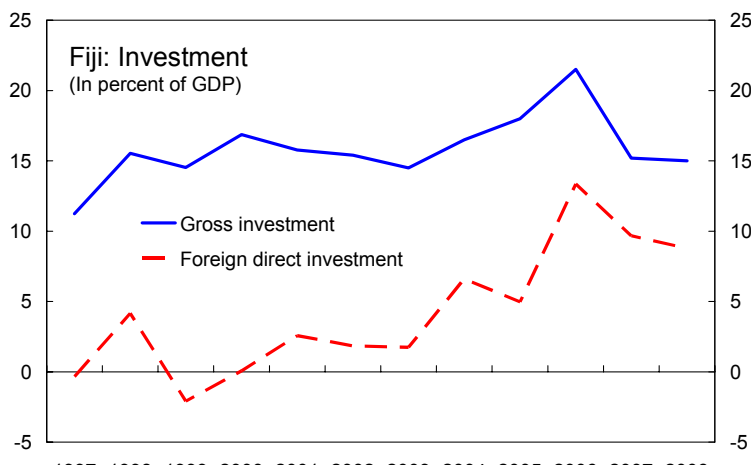

199719981999200020012002200320042005200620072008 Sources: Fiji authorities; and Fund staff estimates.

The real effective exchange rate appreciated through 2008, despite the decline in the terms of trade.

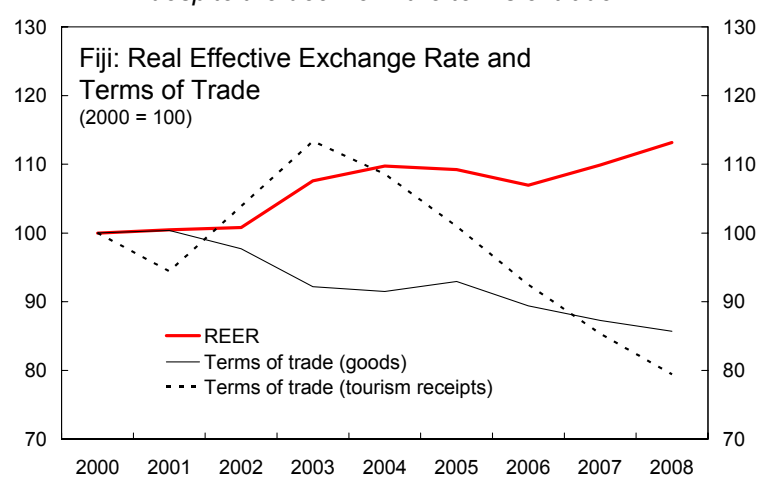

Sources: Global Economic Environment Database; and Fund staff estimates.
Real GDP per capita declined in recent years.

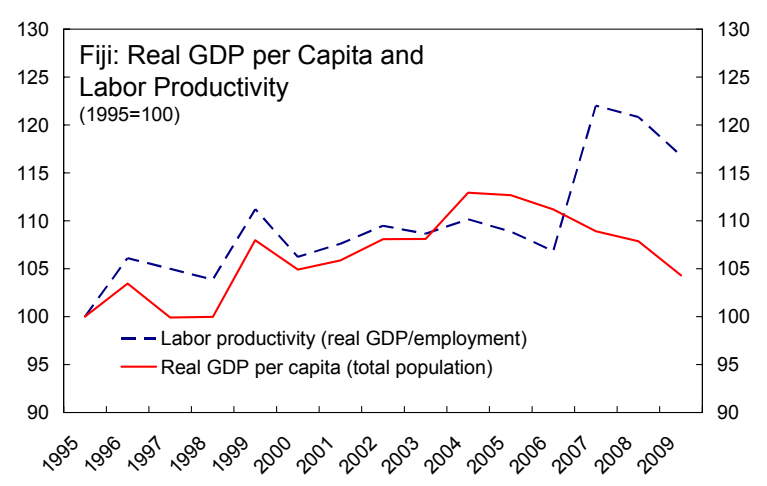

Sources: Fiji Islands Bureau of Statistics; and Fund staff estimates.

Investment remains low by international standards.

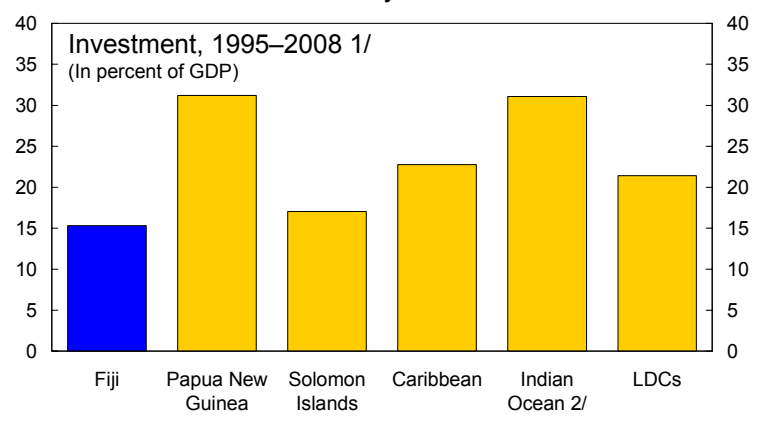

Sources: IMF, World Economic Outlook database; and Fund staff calculations. 1/ Simple averages.

2/ Mauritius, Seychelles, and Maldives.

Increasing emigration has deprived the economy of skilled labor, while unemployment has risen steadily.

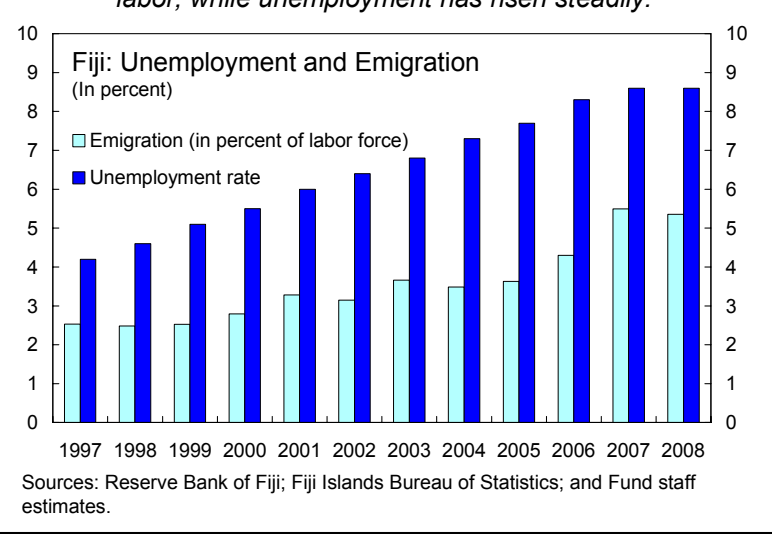


Figure 2. Fiji: Impact of Global Crisis on Pacific Island Countries

Economic activity slowed partly as a result of the global crisis...

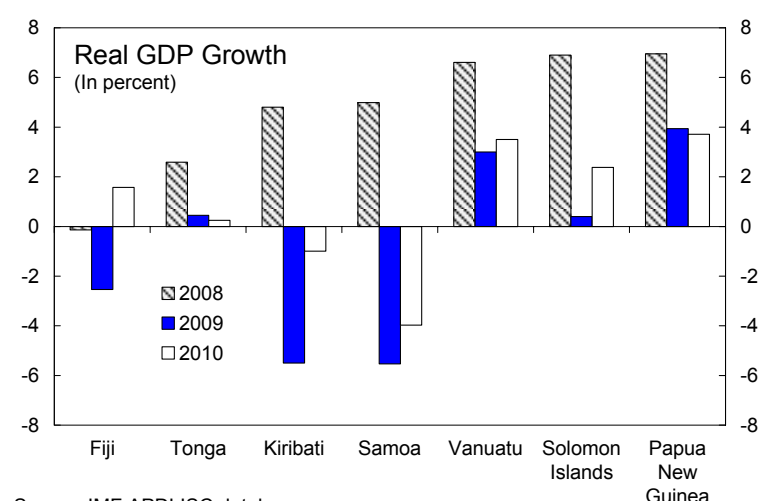

Source: IMF APDLISC database.

Tax revenue fell as activity declined, putting pressure on fiscal balances...

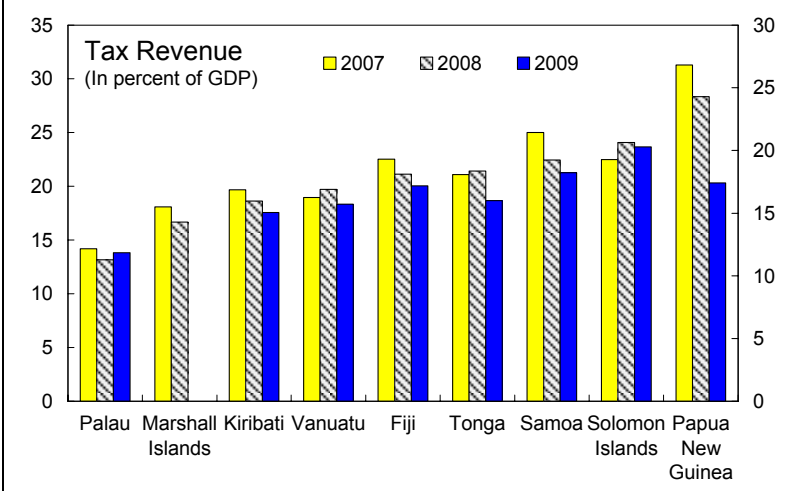

Source: IMF APDLISC database.

Imports slowed in 2009 because of falling domestic demand and lower commodity prices..

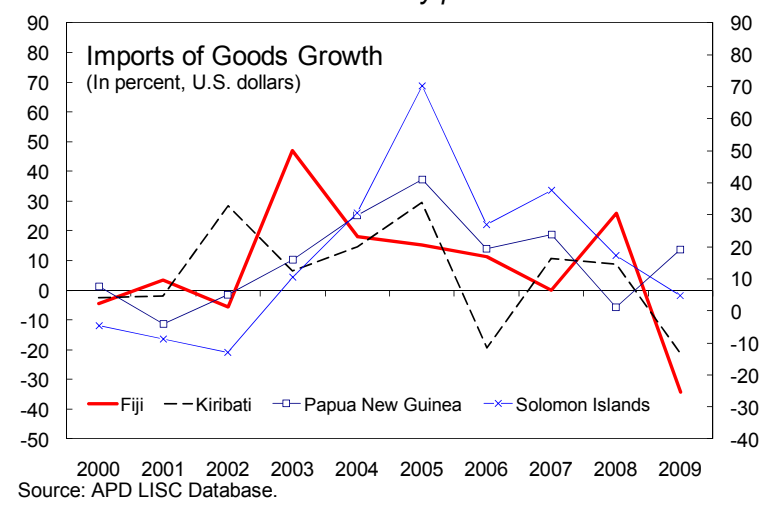

.... while the decline in commodity prices has helped PICs to keep down inflation.

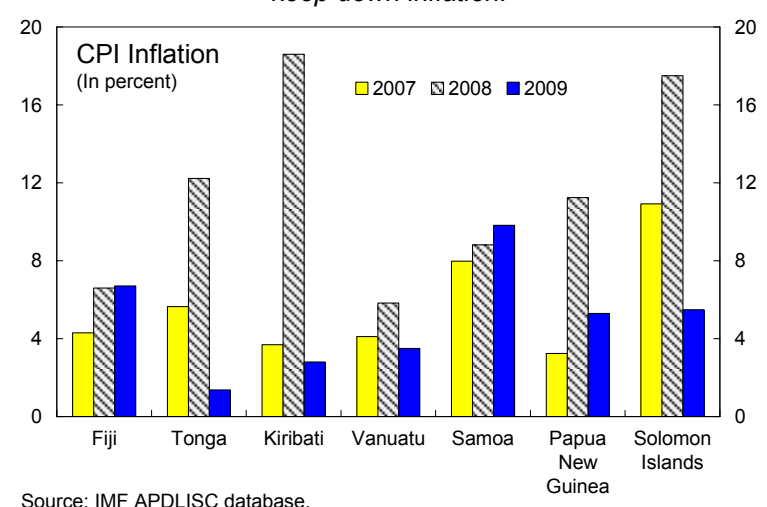

...and exports declined in most countries because of lower external demand.

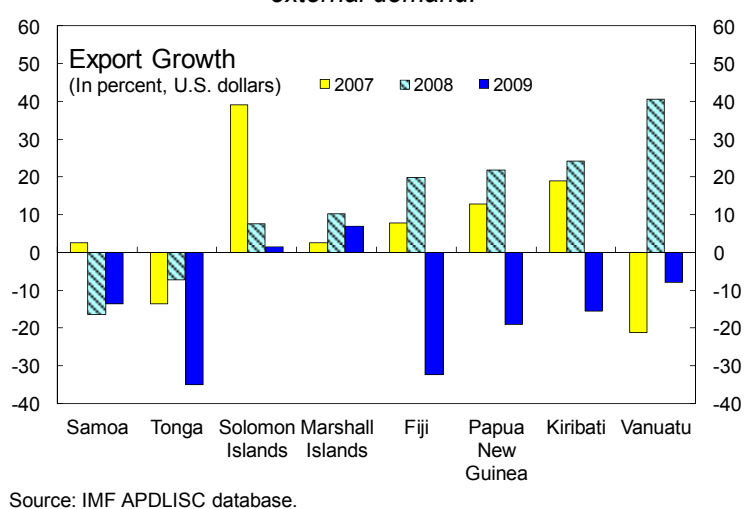

Source: IMF APDLISC database.

...while credit growth decelerated.

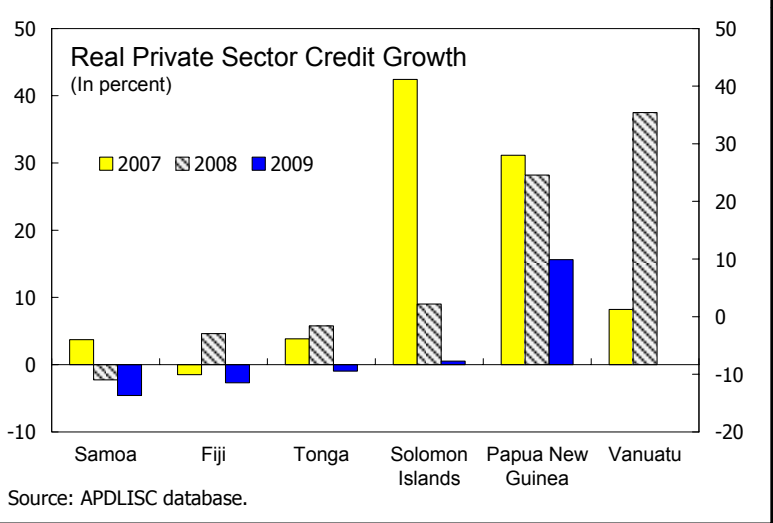


Figure 3. Fiji: Exchange Rate and Inflation Developments

The April 2009 devaluation has resulted in significant competitiveness gains so far.

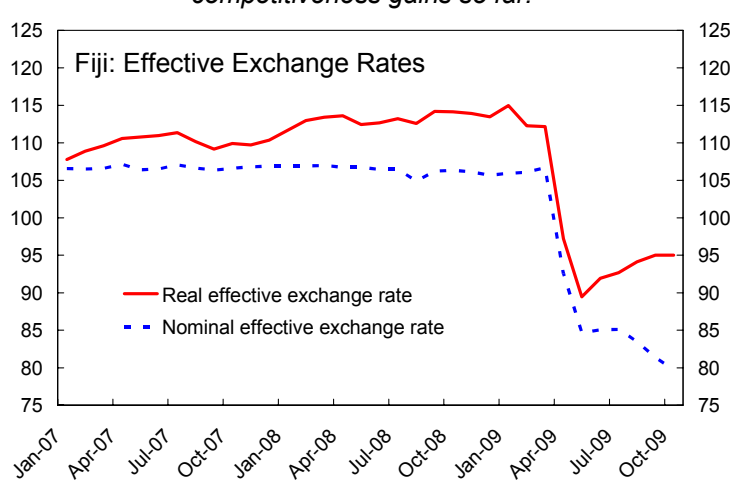

Source: IMF, Information Notice System; and Fund staff estimates.

Annual inflation (year-on-year) has increased because of the devaluation...

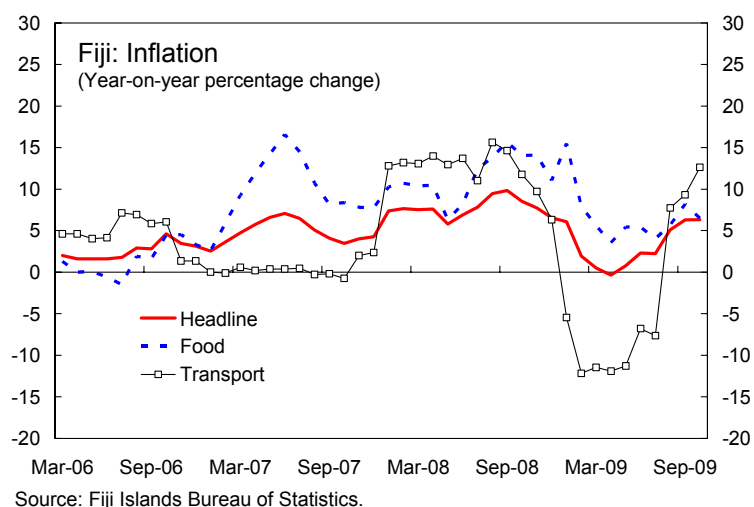

Reserves increased following the devaluation...

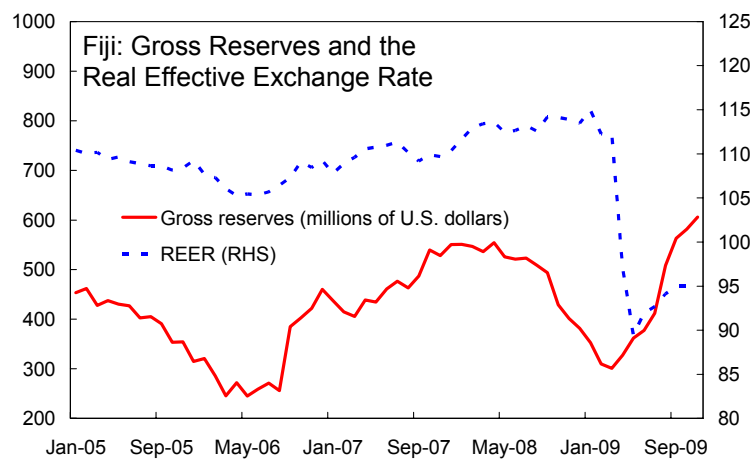

Sources: Reserve Bank of Fiji; IMF, Information Notice System; and Fund staff estimates.
With a larger depreciation against the Australian dollar than the U.S. dollar in recent months because of U.S. dollar weakness.

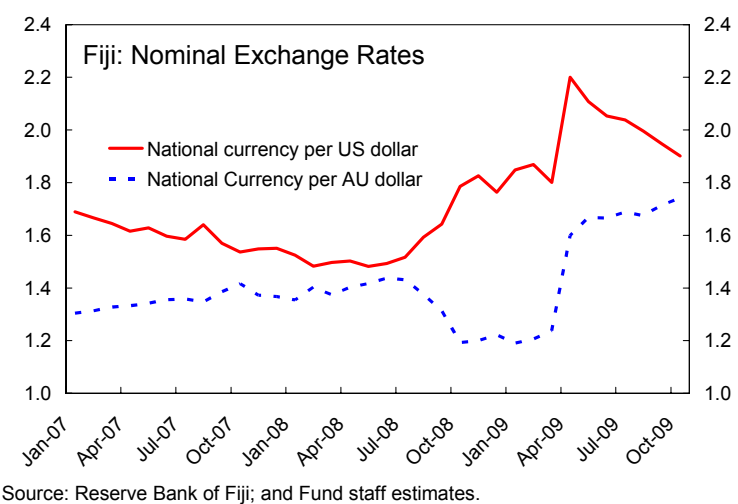

...but seasonally adjusted and core measures suggest that inflation may have already peaked.

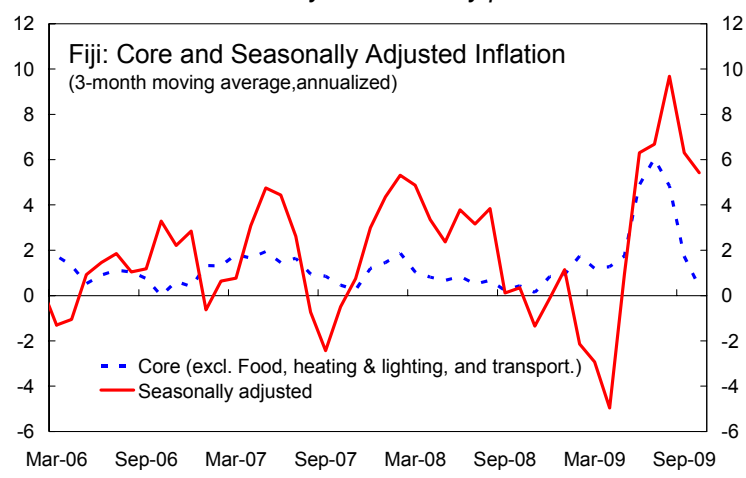

Sources: Fiji Islands Bureau of Statistics; and Fund staff calculations.

...and because of the SDR allocation and repatriation of the Fiji National Provident Fund assets.

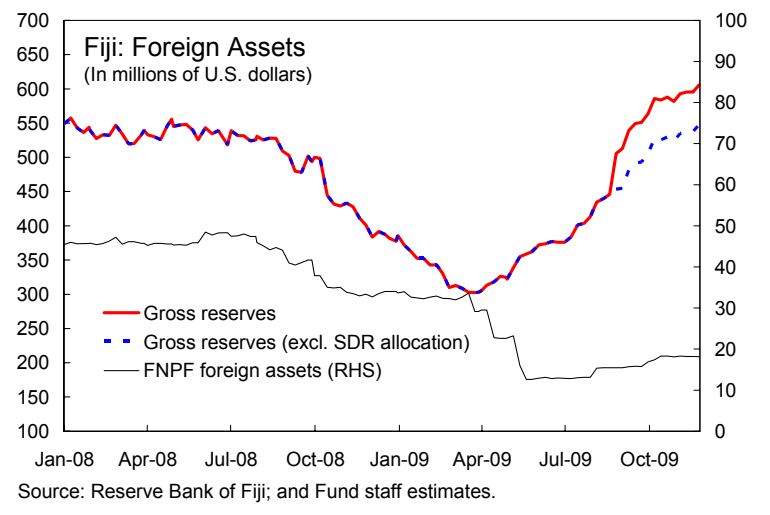

\section{CInternational Monetary Fund. Not for Redistribution}


Figure 4. Fiji: Balance of Payments

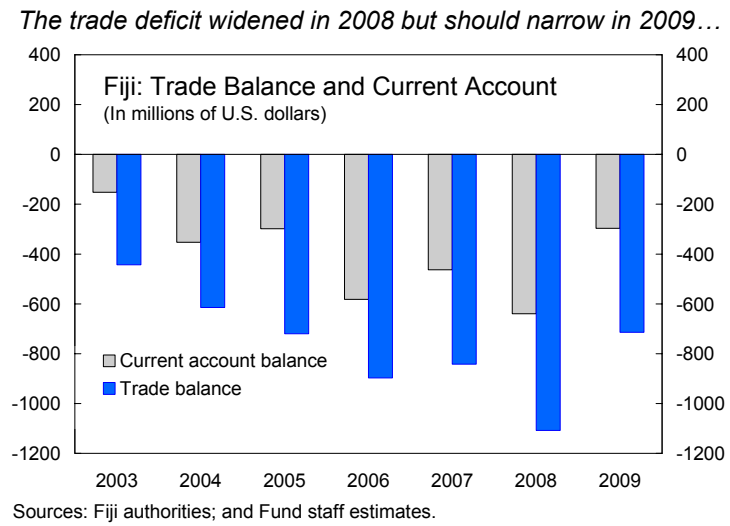

Sources: Fiji authorities; and Fund staff estimates.

Imports fell sharply in 2009 because of the devaluation, the economic slowdown..

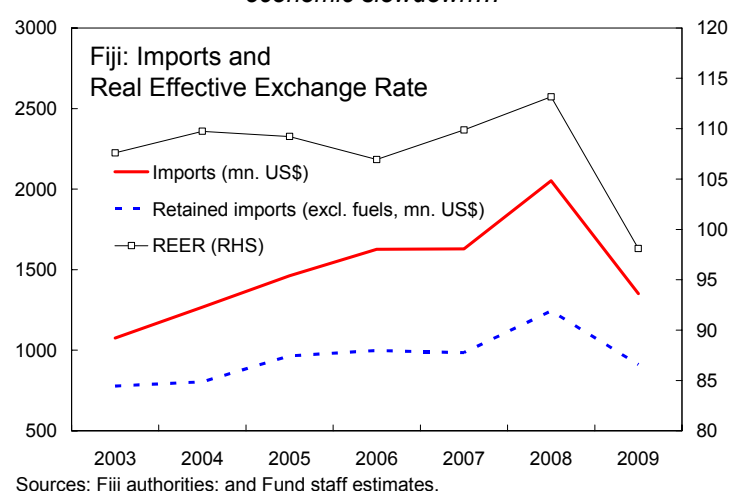

...while exports fell in 2009.

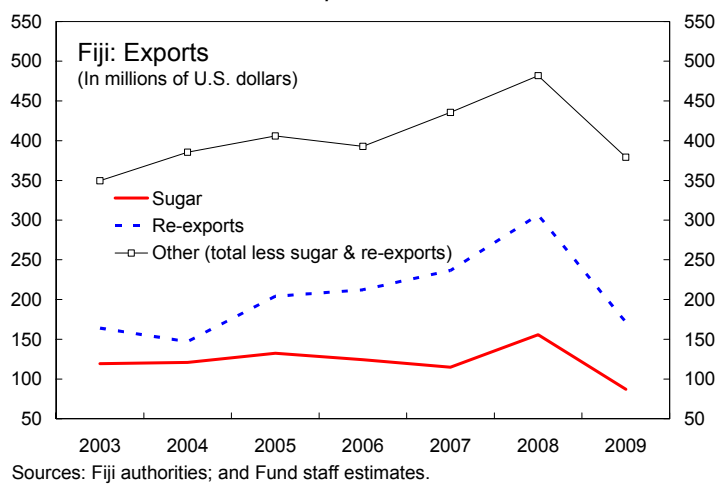

...and lower oil prices.

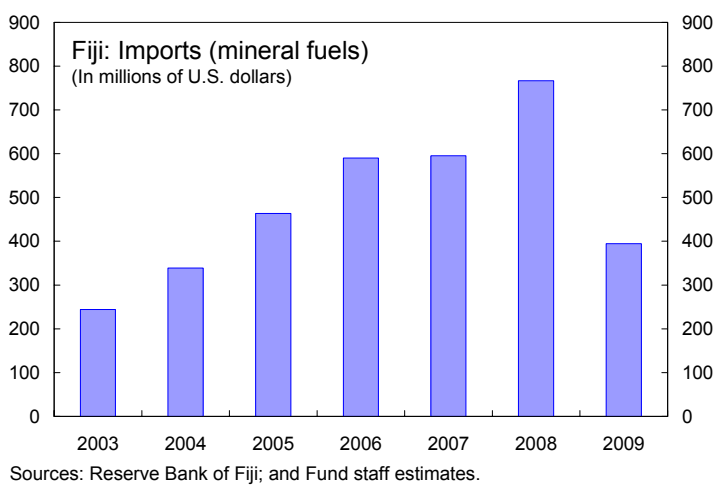

Provident Fund (FNPF, a public pension fund). Tighter exchange controls also played a role in the reserve accumulation.

\section{Tourist arrivals fell by almost 25 percent year-on-year in early 2009 because of} the global crisis and January floods, but recovered mid-year (Figure 5). A pickup in Australian tourists drove the rebound, as the Australian economy recovered from the global crisis and the devaluation of the Fijian dollar against the Australian dollar made Fiji a more attractive destination.

8. Recent developments have put considerable pressure on the budget. Tax revenue was hit by the fall in economic activity, with a shortfall of about 10 percent relative to the budget in the first 10 months of the year. Capital spending increased to address infrastructure needs and rebuild after the floods, but was limited overall by weaknesses in implementation capacity. Government also restrained current spending by containing wage increases. 
Figure 5. Fiji: Tourism Developments Affecting Fiji

Tourism has increased over the past six years, but was hurt by the 2006 coup.

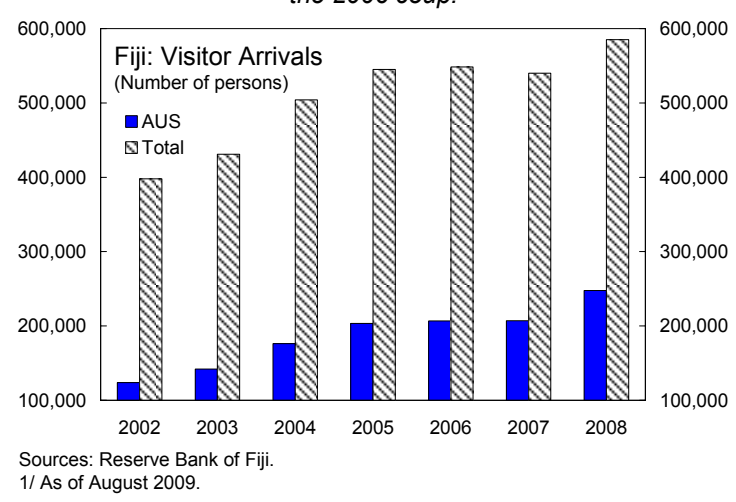

Hotel capacity remains underutilized...

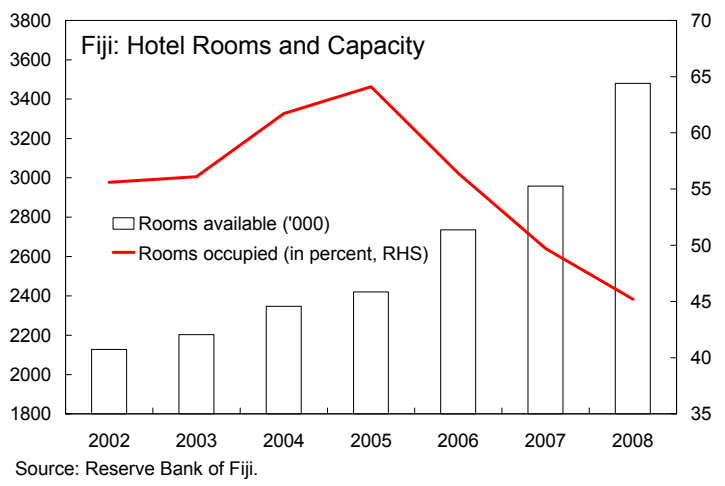

Tourism earnings (in Fijian dollars terms) have improved...

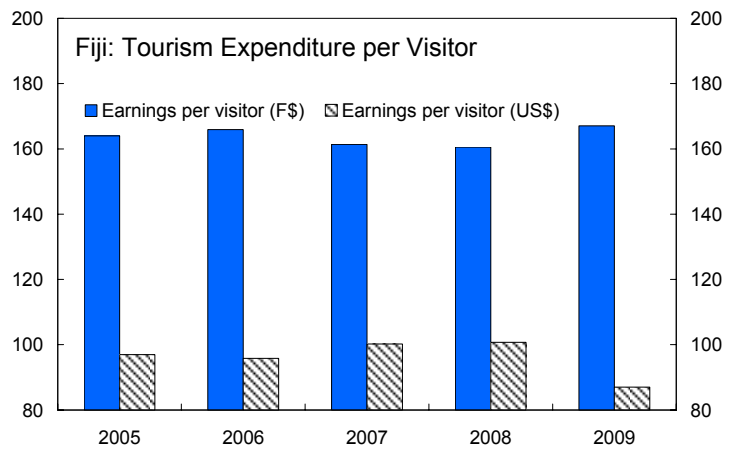

Sources: Reserve Bank of Fiji; and Fund staff calculations.
For 2009, tourist arrivals fell in first half because of the global crisis and flooding.

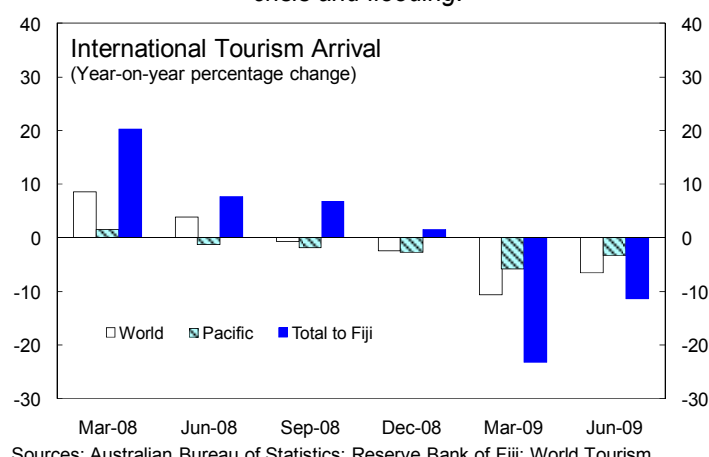
Sources: Australian Bureau of Statistics; Reserve Bank of Fij; World Tourism barometer.

... but the recent devaluation makes Fiji a more attractive tourism destination.

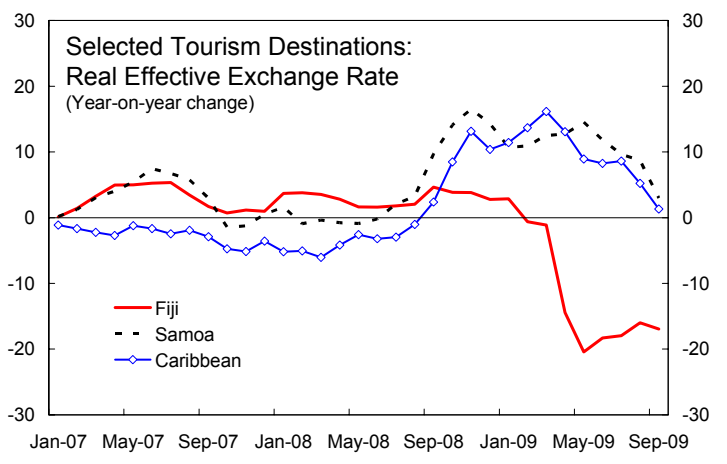
Soures: IMF, Information Notice System.

and tourist arrivals from Australia shows signs of a rebound.

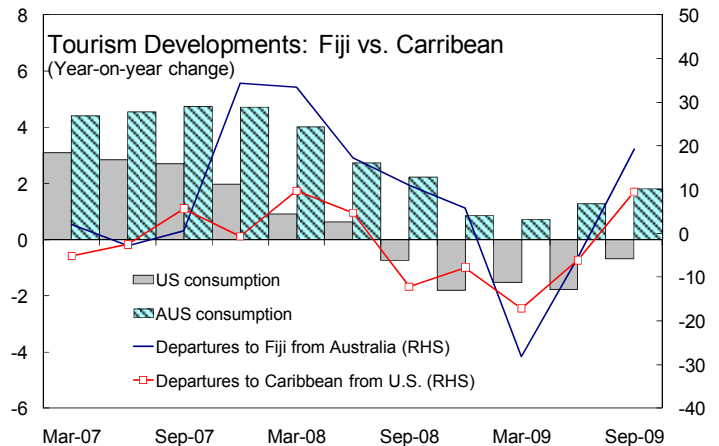
Soures: Australian Bureau of Statistics; Haver Analytics; World Economic Outlook. 
9. The fiscal deficit increased to about 3 percent of GDP in 2009 from near balance in 2008 (Figure 6, Table 2). Preliminary data on financing shows that the FNPF provided most of the funding, as bank lending to government reached sovereign exposure limits. Central government debt is expected to rise to 53 percent of GDP by end 2009.

10. Contingent liabilities arising from poor performance of public enterprises are sizable. Net losses of the Fiji Sugar Corporation, Fiji Electricity Authority and Air Pacific amounted to 1 percent of GDP in 2008/09 and entail fiscal risks, while central government guarantees of public enterprise debt amount to 15 percent of GDP at end 2008.

11. Bank liquidity has risen sharply in recent months but credit growth has slowed. Banks' excess reserves fell to near zero in early 2009 as foreign exchange reserves declined, but have risen to historically high levels (more than 13 percent of deposits) as forex reserves have recovered (Figure 7, Table 3). Bank credit to the private sector picked up in 2008, but is likely to contract in real terms in 2009, as banks have taken a cautious approach in light of heightened political and economic uncertainties. Nonbank lending expanded rapidly, with FNPF's new lending to the private sector and quasi-government agencies exceeding total new lending by banks in the year to June 2009. However, FNPF's management has since restricted new lending.

\section{The RBF has begun to absorb excess liquidity and remove interest rate and} credit controls. To make loans affordable, RBF introduced ceilings on bank lending rates (73/4 percent on average) and bank spreads (4 percent) in early 2009 . However, these measures discouraged banks from lending as they were forced to concentrate on low-risk clients. In recent months, the RBF announced the removal of ceilings on banks' lending rates and spreads by January 2010 and removed bank-by-bank credit ceilings. The RBF also increased the statutory reserve requirement on banks from 5 to 7 percent of deposits, to reduce excess liquidity.

13. The external current account deficit is expected to narrow to about 9 percent of GDP in 2009, still high by regional standards (Figure 8, Table 4). Despite high current account deficits in recent years, external debt is low at 13 percent of GDP in 2008, as deficits were financed mainly by FDI in the tourism sector. External financing from official sources has been limited since the 2006 coup. The AsDB approved an emergency assistance loan of US $\$ 17 \frac{1}{2}$ million in August 2009 for flood damage. Loans for infrastructure of over US\$200 million are under negotiation with banks overseas.

\section{B. Outlook and Risks}

14. GDP growth of 2 percent is likely in 2010. Growth will be driven by the rebound in tourism, the global recovery, and rebuilding after the floods. Over the medium term, growth is likely to settle at around $2 \frac{1}{2}$ percent assuming some fiscal consolidation and progress on structural reforms (baseline scenario in text table and Table 5). Stronger growth could be 
Figure 6. Fiji: Fiscal Indicators

Tax revenue declined affected by floods and the global crisis...

...and expenditure was contained but remains high.

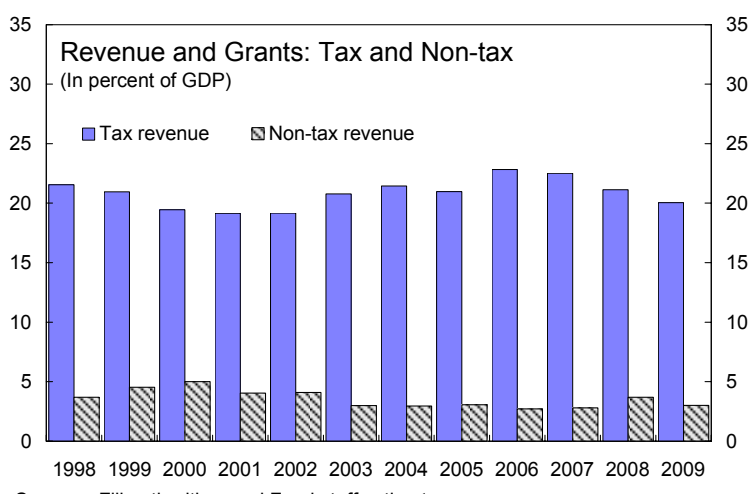

Sources: Fiji authorities; and Fund staff estimates.

The overall balance deteriorated in $2009 \ldots$

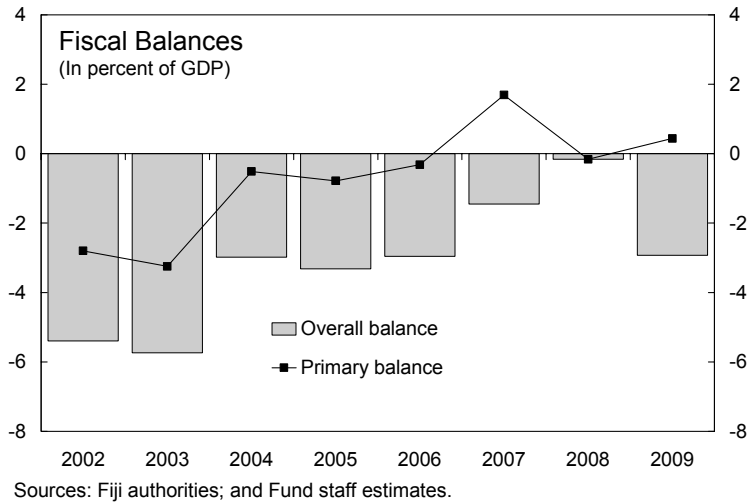

The deficit has been financed mostly domestically.
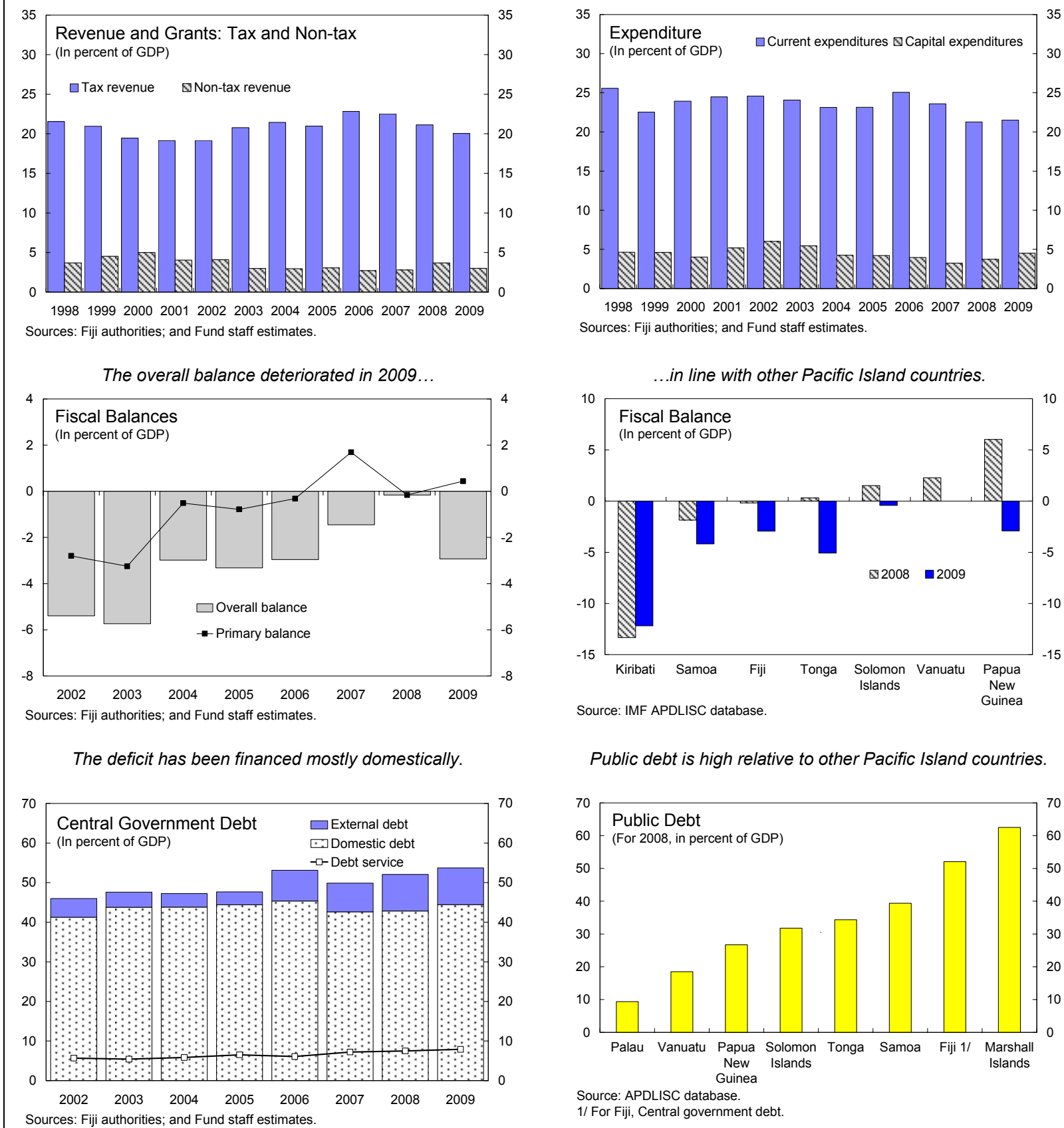
Sources: Fiji authorities; and Fund staff estimates.

...in line with other Pacific Island countries.

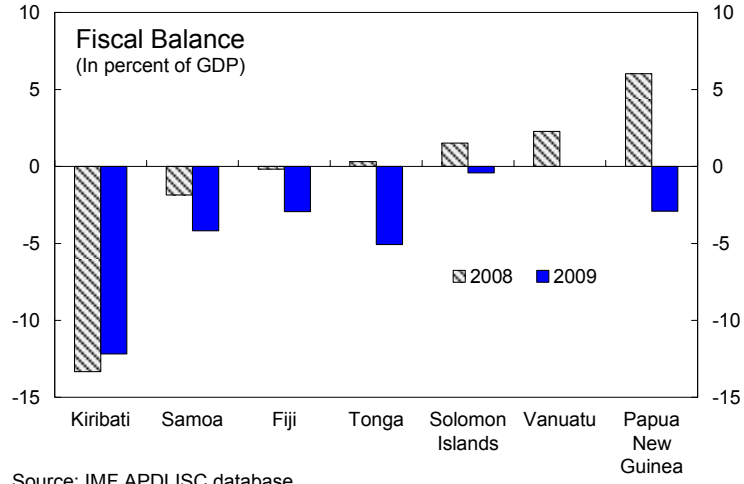

Public debt is high relative to other Pacific Island countries.

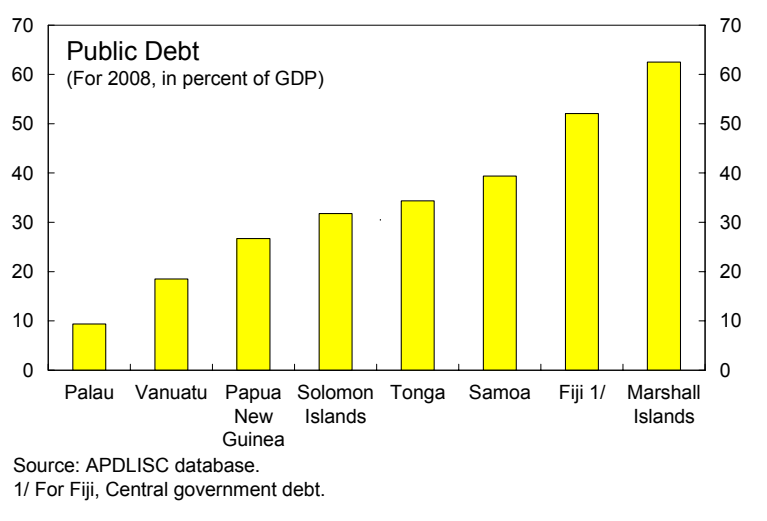


Figure 7. Fiji: Monetary Indicators

Inflation increased along with liquidity following the April 2009 devaluation.

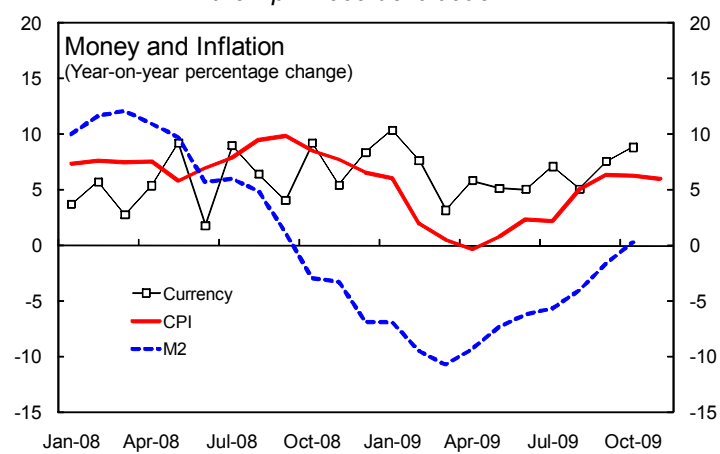

Source: Reserve Bank of Fiji.

Business loans are still growing faster than housing loans...

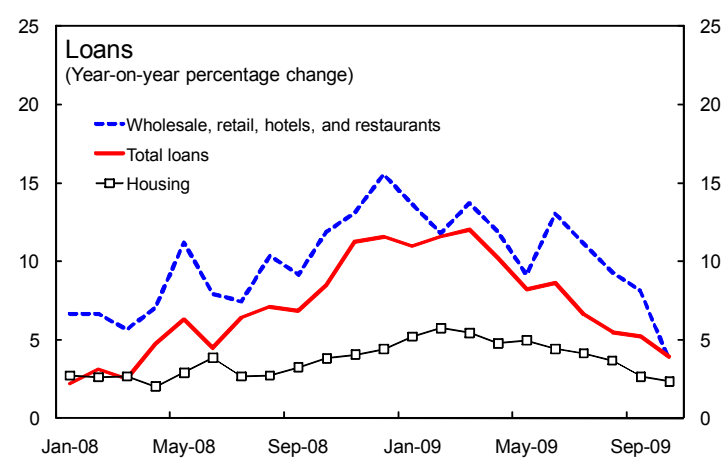

Source: Reserve Bank of Fiji.

Government bond and deposit interest rates increased...

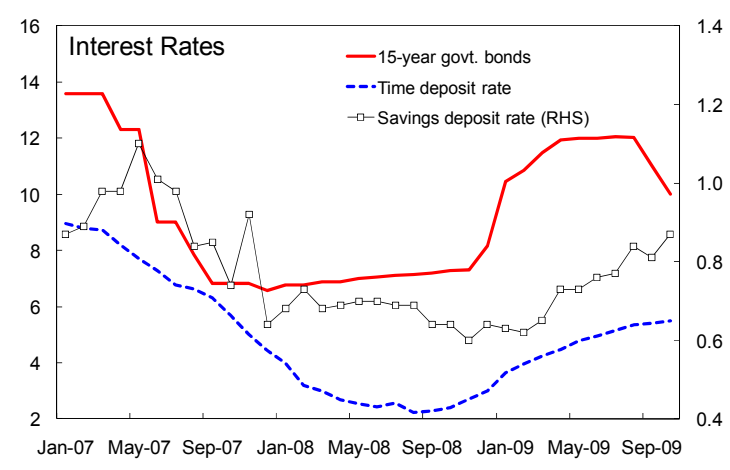

Source: Reserve Bank of Fiji.
Banks reserves held at the central bank increased but loan growth decelerated.

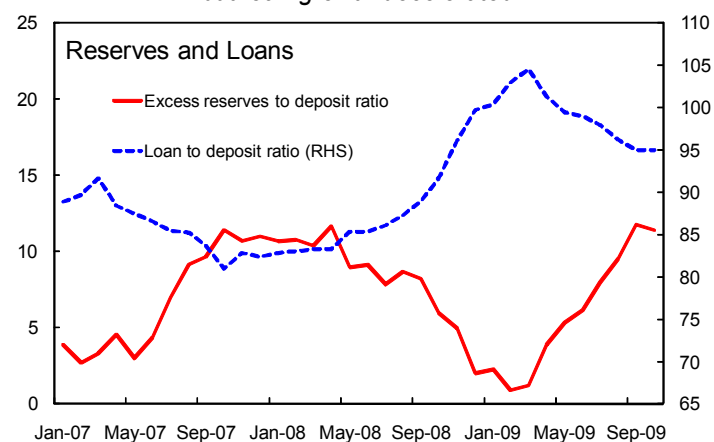

Jan-07 May-07 Sep-07 Jan-08 May-08 Sep-08 Jan-09 May-09 Sep-09 Source: Reserve Bank of Fiji.

...and bank lending rates decreased slightly.

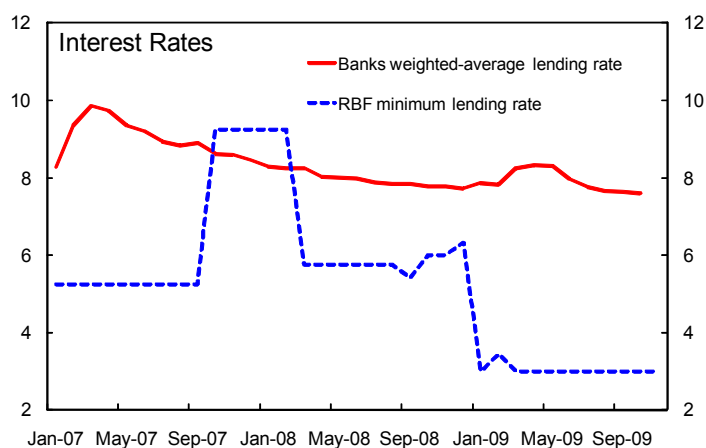

Source: Reserve Bank of Fiji.

...and the FNPF remains the largest holder of government securities.

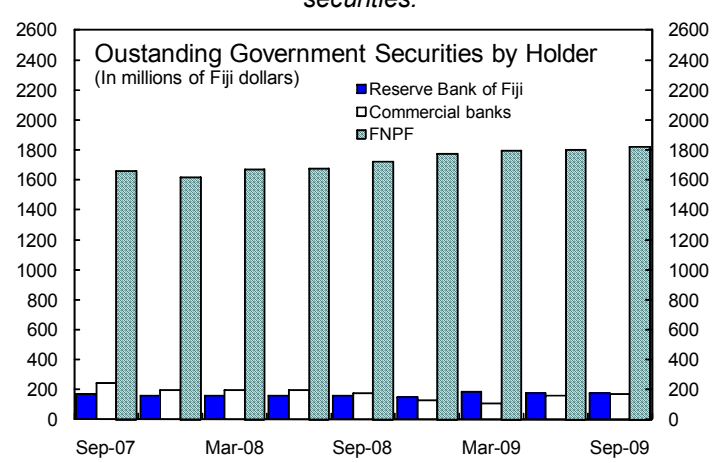

Source: Reserve Bank of Fiji. 
Figure 8. Fiji: External Vulnerabilities

The current account deficit is large by Pacific Island standards.

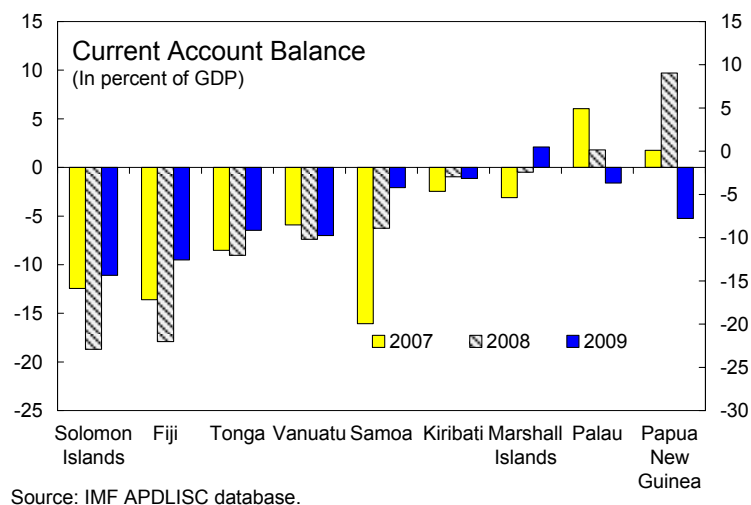

Source: IMF APDLISC database.

The trade balance is sensitive to changes in oil prices.

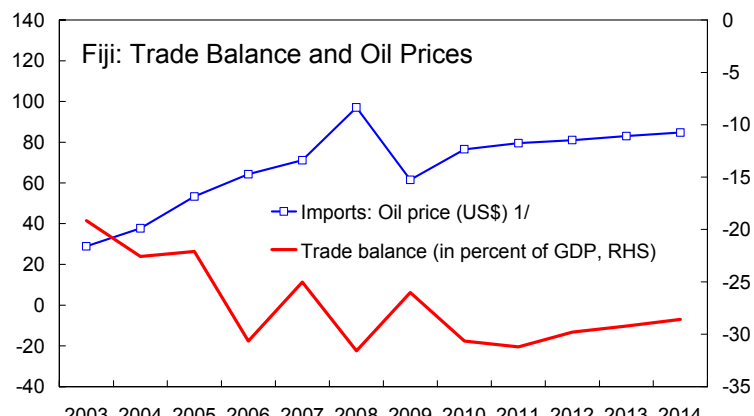

200320042005200620072008200920102011201220132014

Sources: Global Assumptions Database; and Fund staff calculations.

$1 /$ Crude Oil (petroleum), simple average of three spot prices; Dated Brent, West Texas Intermediate, and the Dubai Fateh, US\$ per barrel.

Fiji's foreign exchange reserves reached a level close to neighboring countries in 2009.

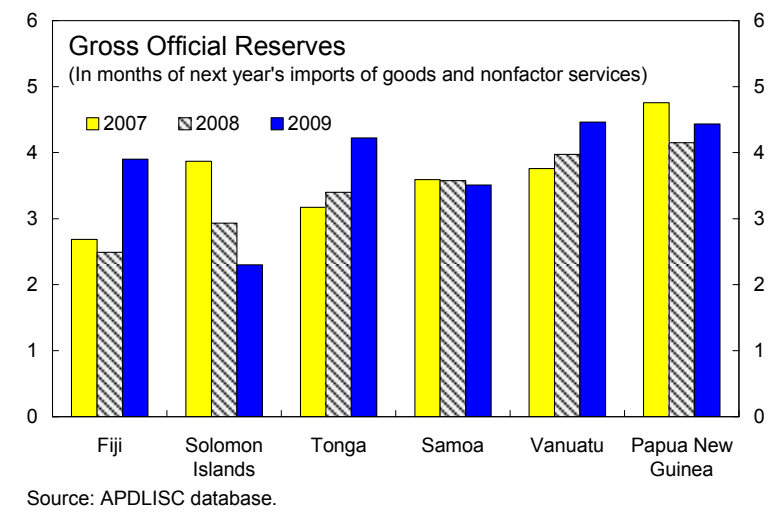

But external public debt is lower than in other Pacific Island countries.

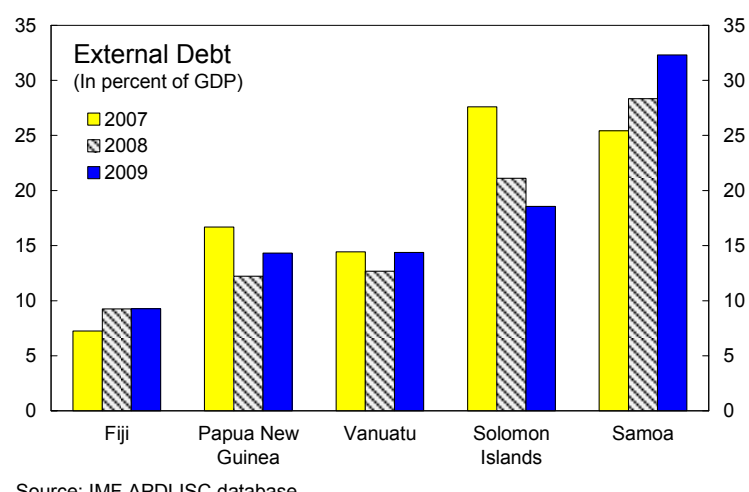

Source: IMF APDLISC database.

Compounded by low diversification of exports.

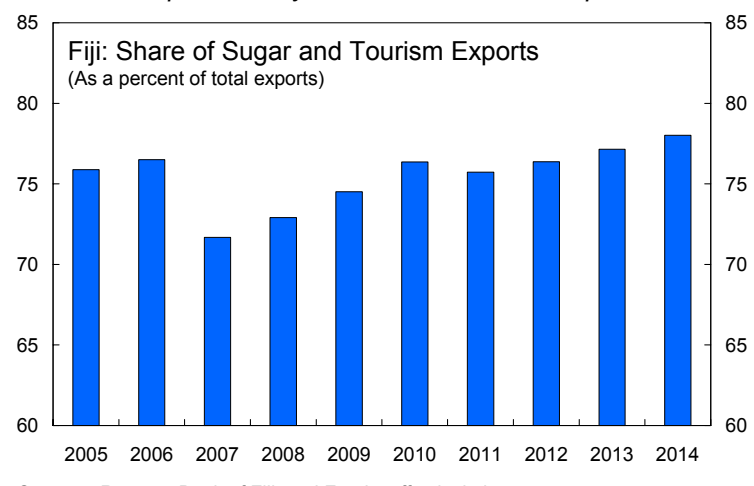

Sources: Reserve Bank of Fiji; and Fund staff calculations.

Debt servicing jumps in 2011 because of the maturity of a sovereign bond.

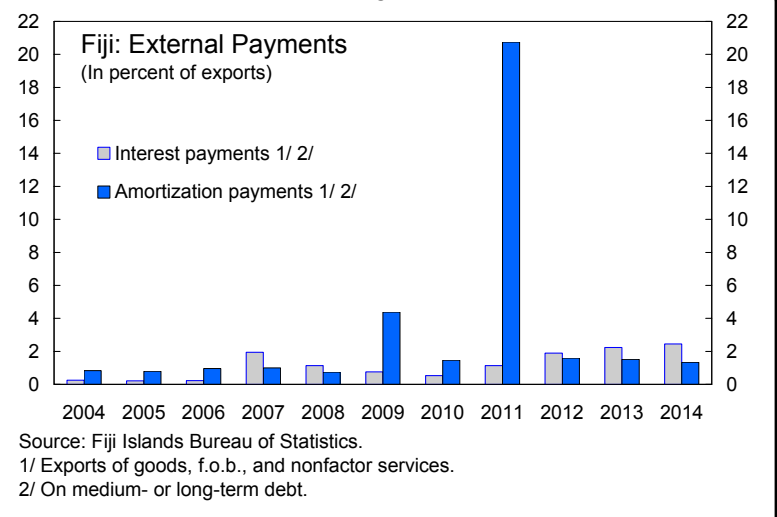


achievable with greater fiscal adjustment and significant progress on structural reforms, especially civil service and land reform.

\section{There are considerable risks to macroeconomic and external stability if sound} policies are not pursued. A downside scenario would see a continuation of sluggish GDP and export growth and a depletion of reserves, with heightened risks in 2011 when the US\$150 million sovereign bond falls due (text table). Main downside risks are:

- Increased liquidity may translate into higher inflation, undermining macroeconomic stability, and eroding competitiveness.

- Slow progress in reducing the budget deficit could threaten fiscal sustainability.

- $\quad$ Structural reforms may be delayed further if the political complexities of civil service and land reforms are not resolved.

- $\quad$ The economy is vulnerable to a variety of shocks, including a decline in external demand for tourism and exports, higher oil prices, natural disasters, and political tensions.

- $\quad$ The reliance on tourism as the main source of growth increases Fiji's vulnerability to shocks. Moreover, environmental concerns may limit growth potential in tourism.

16. The authorities broadly agreed with the outlook. They expect tourism arrivals to pick up with new airline routes and business confidence to recover with progress on structural reforms.

\begin{tabular}{|lrrrrrr|}
\hline \multicolumn{5}{|c|}{ Illustrative Medium-Term Scenarios } \\
\hline
\end{tabular}




\section{Policy Discussions}

\section{A. Fiscal Policy}

\section{Staff commended the authorities for containing the overall deficit to about} 3 percent of GDP in 2009 in the face of an unexpectedly sharp fall in revenue. Expenditure restraint limited the deficit to about the level projected in the November 2008 budget, even though the flooding in early 2009 hit revenues and increased the need for spending. Restraining expenditures was appropriate, though some spending cuts are not sustainable.

18. The authorities are targeting a deficit of $3 \frac{1}{2}$ percent of GDP in the 2010 budget. Capital spending is projected to rise by more than $1 / 2$ percent of GDP because of rebuilding in flood-affected areas and upgrading of infrastructure. Current expenditure is budgeted to fall relative to GDP, with no civil service wage increase and some redundancies as a result of corporatization of the water authority, government printing and procurement. The deficit would be about $3 \frac{1}{4}$ percent of GDP excluding the cost of redundancy packages.

\section{To safeguard macroeconomic stability, staff advised a more substantial} reduction in the deficit to about 2 percent of GDP in 2010 (excluding the cost of civil service reform). High central government debt and contingent liabilities (together about 70 percent of GDP excluding FNPF) call for a lower deficit to ensure fiscal sustainability. A lower deficit would reduce the risk of RBF financing, which could be inflationary, and reduce pressure on foreign exchange reserves, given limited external financing. Staff supported an increase in capital spending to address infrastructure needs, but noted that cuts in current expenditure are needed to limit the deficit. Staff also strongly recommended that all capital expenditure be recorded in the budget. ${ }^{1}$

\section{Over the medium-term, the authorities intend to reduce the budget deficit} gradually and thereby lower central government debt to 50 percent of GDP by 2014 . In order to ensure sustainability, staff urged a faster pace of consolidation in line with the authorities' earlier plans (in the 2009 budget) to reduce central government debt to 45 percent of GDP by 2014. A faster pace of fiscal consolidation would be necessary in the absence of pension reforms at the FNPF (see below).

\section{Staff stressed that fiscal consolidation will require credible expenditure and} revenue measures. Substantial efforts are needed to reduce the wage bill through welldesigned civil service reform. In addition, there is potential to trim subsidies by better targeting assistance to vulnerable groups and to improve expenditure management by enhancing transparency and accountability (Table 6). Revenue can be strengthened by

\footnotetext{
${ }^{1}$ Externally-financed infrastructure spending of 2-3 percent of GDP for 2011-13 is recorded outside the budget to simplify procurement procedures for these projects.
} 
eliminating tax holidays, streamlining tax incentives, and improving tax administration (Table 7). ${ }^{2}$ Excise taxes on luxury goods and taxes on petroleum could be raised and the VAT rate increased if necessary.

\section{B. Monetary Policy}

22. Staff and the authorities project inflation to rise to 7-8 percent $\mathbf{y} / \mathbf{y}$ by early 2010 . Staff pointed to the risk that inflation would not return to low levels if higher inflation expectations fed into wage agreements. The authorities observed that wage increases have been muted thus far, but business contacts were concerned about potential increases in minimum wages.

23. Staff argued for a tightening of monetary policy. A tighter stance is needed to avoid a loss of foreign exchange reserves and lock in the competitive gain from the devaluation by ensuring that inflation falls to about 3 percent by end-2010 (as in staff's baseline projection). Staff welcomed the recent increase in the statutory reserve deposit ratio and the removal of the ceiling on banks' lending rates and spread. But more action is needed given that banks' excess reserves have risen sharply. Excess liquidity should be mopped up by further raising the reserve requirement, issuing RBF bills at market rates, and establishing a standing deposit facility. In addition, RBF financing of the government should be strictly limited.

24. Staff advised a simplification of the monetary operations framework. This can be achieved by making the interest rate on a new standing deposit facility the policy rate, that is set in line with monetary policy objectives. To tighten policy at this point, the policy rate should be higher than the RBF's current minimum lending rate of 3 percent. In addition, the RBF should discontinue the policy of directing lending to priority areas since this distorts bank lending decisions.

\section{The authorities agreed on the need to tighten monetary policy and simplify the} framework. They are considering further steps to remove excess liquidity but did not see the need for a substantial increase in interest rates given the fragile economic outlook.

\section{Financial Sector Policy}

26. FNPF dominates the financial sector and its performance has weakened. FNPF assets are equivalent to 60 percent of GDP, half of which are held in government debt. FNPF's nonperforming assets have increased to 20 percent of total assets. In the past year, FNPF has been pressured to accept low interest rates on government debt, liquidate some international assets, and fund losses of public enterprises.

\footnotetext{
${ }^{2}$ Better tax administration reduced tax arrears from 3 to 2 percent of GDP in the past two years.
} 
27. Staff advised fundamental reform of the FNPF to make it actuarially sound. The authorities are awaiting completion of a study by consultants before taking action and are considering opening the superannuation industry up to competition. A fundamental measure would be to reduce the generous rate of conversion of benefits to annuities to protect FNFP's reserves and thereby reduce the government's contingent liability. ${ }^{3}$ Additional measures include:

- $\quad$ Making FNPF's management independent of government and responsible to beneficiaries.

- $\quad$ Improving risk management as recommended by the RBF in their September 2009 supervision report.

- $\quad$ Reducing government's reliance on FNPF to finance its deficit and losses of public enterprises since this undermines the fund's soundness.

- Curtailing lending to the private sector until new governance is in place, given FNPF's history of poor lending decisions.

28. The RBF has enhanced bank supervision but further steps are needed. Banks appear sound, with strong profits, low nonperforming loans and high capital (Figure 9). Stress tests, however, show some vulnerabilities in smaller banks. These tests should be reviewed with banks and timely remedial actions taken if needed, including by raising capital. In addition, the RBF should enhance risk-based analysis and supervision of banks and FNPF. Progress has been made on a number of recommendations of the 2006 FSAP mission, including steps to make the RBF more independent (Table 8).

\section{External Vulnerabilities and Financing Gap}

29. The external current account deficit is projected to remain sizable at 1012 percent of GDP over the medium term. This assumes that the real effective exchange rate settles at 12-13 percent below the pre-devaluation level, tourism recovers, and that financing is available on reasonable terms to fund the current account deficit.

\section{External vulnerabilities arise from natural disasters, the narrow export base, and volatility of import prices.}

- Although reserves exceed total external debt, higher coverage than the current $31 / 2-$ 4 months of imports would be prudent in light of the risk of natural disasters, such as the flooding in early 2009 and the tsunami that hit Samoa and Tonga in late 2009.

\footnotetext{
${ }^{3}$ The government contingent liability associated with FNPF arises primarily from the unfunded portion of annuities. With the current rate of conversion of benefits to annuities of 15 percent, FNPF reserves could be depleted by 2029. An actuarially fair rate of conversion would be around 10 percent.
} 


\section{Figure 9. Fiji: Financial Soundness Indicators}

Commercial bank assets have risen to 70 percent of GDP

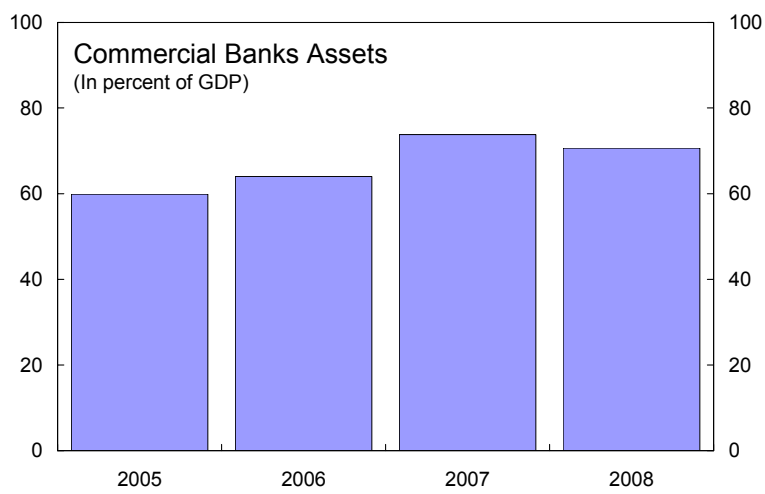

Sources: Reserve Bank of Fiji; and Fund staff calculations.

Capital adequacy is relatively high.

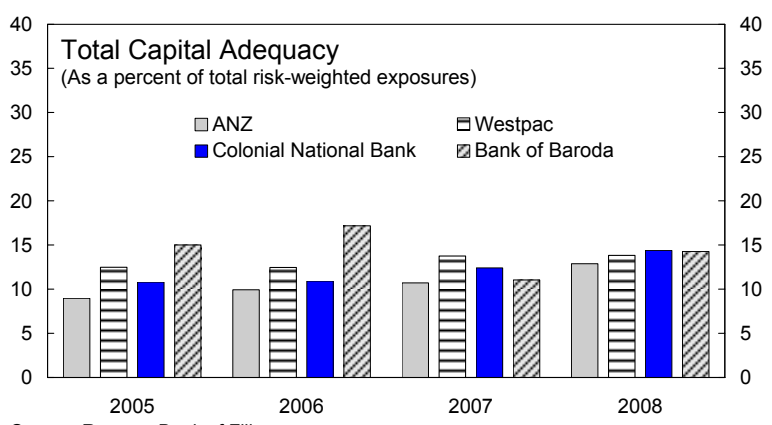

Source: Reserve Bank of Fiji.

$1 /$ September year.

2/ June year.

3/ March year

Although asset quality is generally adequate, some problem loans have emerged, especially at Colonial Bank.

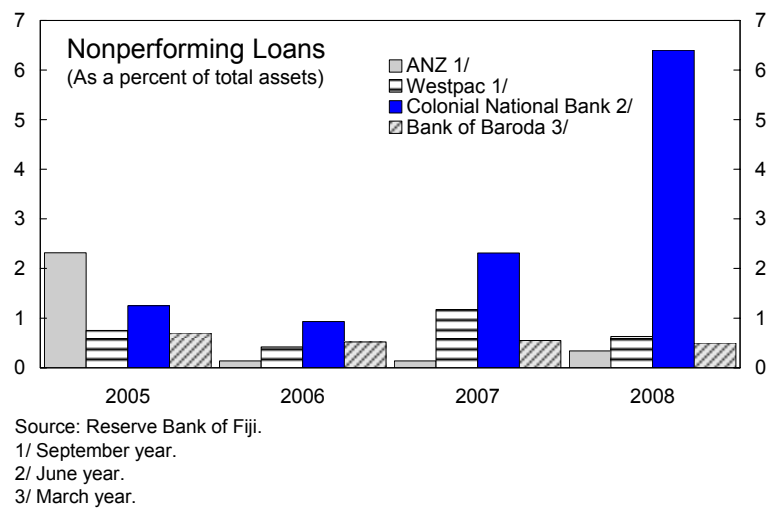

Two Australian-owned branches (ANZ and Westpac) comprise 70 percent of total bank assets.

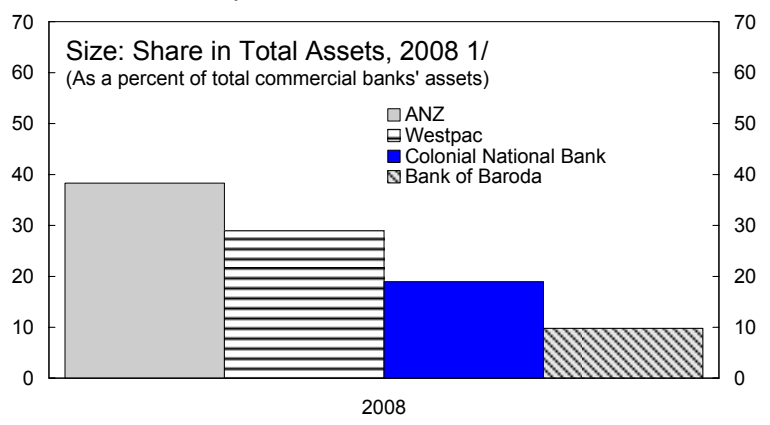

Source: Reserve Bank of Fiji.

1/ 12 months up to September for ANZ and Westpac, up to June for Colonial National Bank, and up to March for Bank of Baroda.

Profits have declined in the past two years, but remain healthy.

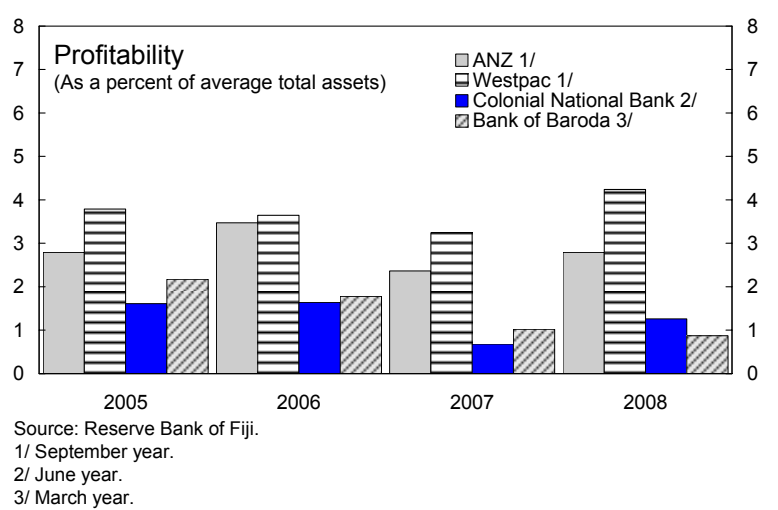

And while provision coverage seems sufficient, it has been declining.

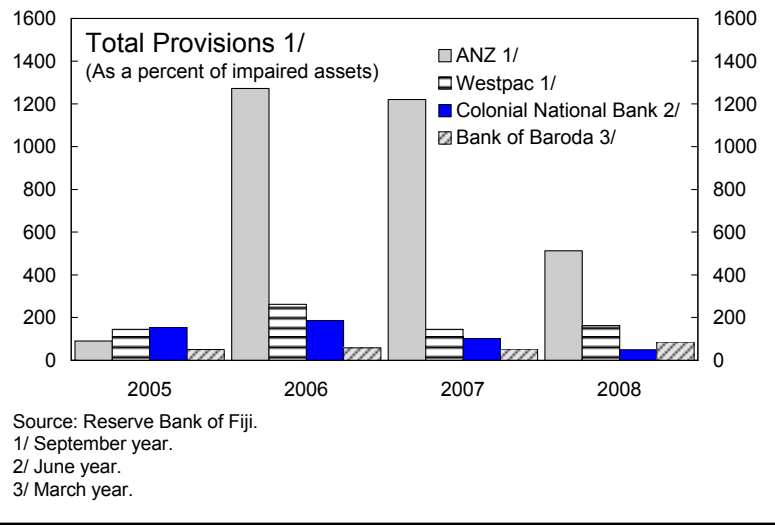


- $\quad$ Forex earnings rely on sugar, tourism, and remittances. Sugar prices have fallen as the EU has lowered its preferential prices, and tourism earnings and remittances have been volatile.

- A sharp increase in oil prices would hit foreign exchange reserves. A US\$10 per barrel increase in world oil prices would increase the oil import bill by about US\$50 million.

\section{Given the external vulnerabilities, estimates of the financing gap are highly} uncertain. Staff's baseline scenario is illustrative only and shows that additional external financing of more than US\$500 million is needed over 2010-12 to keep reserves at a minimum of $3 \frac{1}{2}$ months of imports, assuming some fiscal consolidation and structural reforms. More than half the gap arises in 2011 when a US\$150 million sovereign bond matures, as staff assume this bond is not rolled over and that there is no new financing from international capital markets (text table). The extent of financing from this source depends on the strength of the authorities' economic policies and on political developments that may affect investor confidence. The authorities believe they could fill the financing gap by rolling over the sovereign bond and borrowing from donors or the IMF.

\begin{tabular}{|lrrrr|}
\hline \multicolumn{5}{|c|}{ Summary Balance of Payments: Financing gap } \\
& 2009 & 2010 & 2011 & 2012 \\
\hline & (In millions of U.S. dollars) \\
A. Current account balance & -297 & -493 & -469 & -447 \\
$\quad$ Of which: Regularization of dividend remittances & $\ldots$ & -100 & -80 & $\ldots$ \\
B. Capital and financial acount balance 1/ & 515 & 336 & 201 & 356 \\
$\quad$ Of which: Foreign direct investment & 263 & 264 & 261 & 273 \\
$\quad$ Bond repayment & & & -150 & -91 \\
C. Overall balance (A + B) & 219 & -156 & -269 & -23 \\
D. Targeted change in international reserves 2/ & $\ldots$ & -39 & 23 & 23 \\
Financing gap (D - C) & & 117 & 292 & 114 \\
\hline 1/ Including errors and omissions. & & & & \\
2/ In order to maintain 3.5 months of import coverage. & & & & \\
\hline
\end{tabular}

32. Debt sustainability analysis shows a number of vulnerabilities. Shocks to the outlook could push central government debt to more than 60 percent of GDP by 2014 (Figure 10). While external debt is low at present, a combination of shocks to interest rates, GDP growth and the current account could raise debt to almost 40 percent of GDP (Figure 11). 


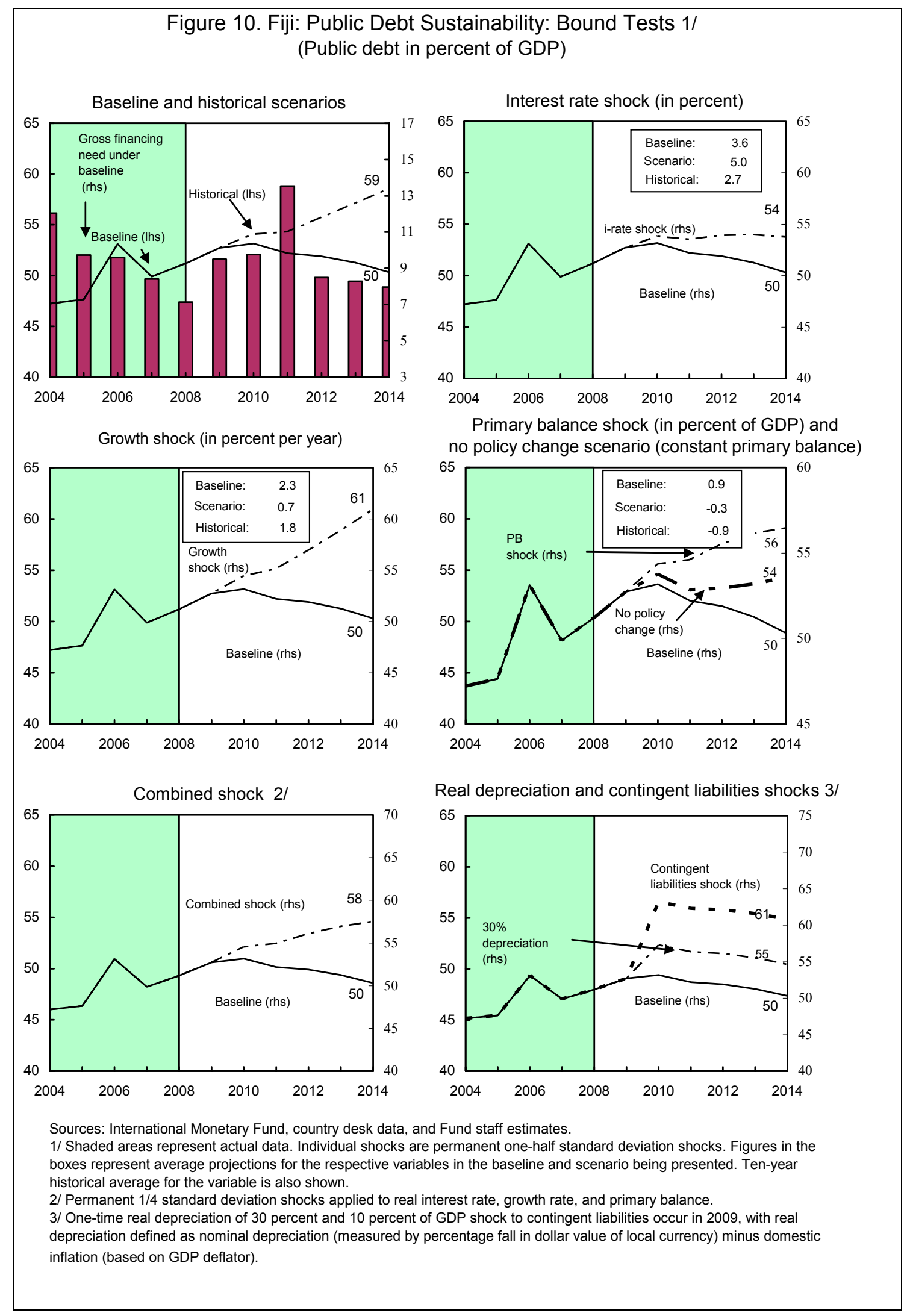

CInternational Monetary Fund. Not for Redistribution 
Figure 11. Fiji: External Debt Sustainability: Bound Tests 1/ (External debt in percent of GDP)
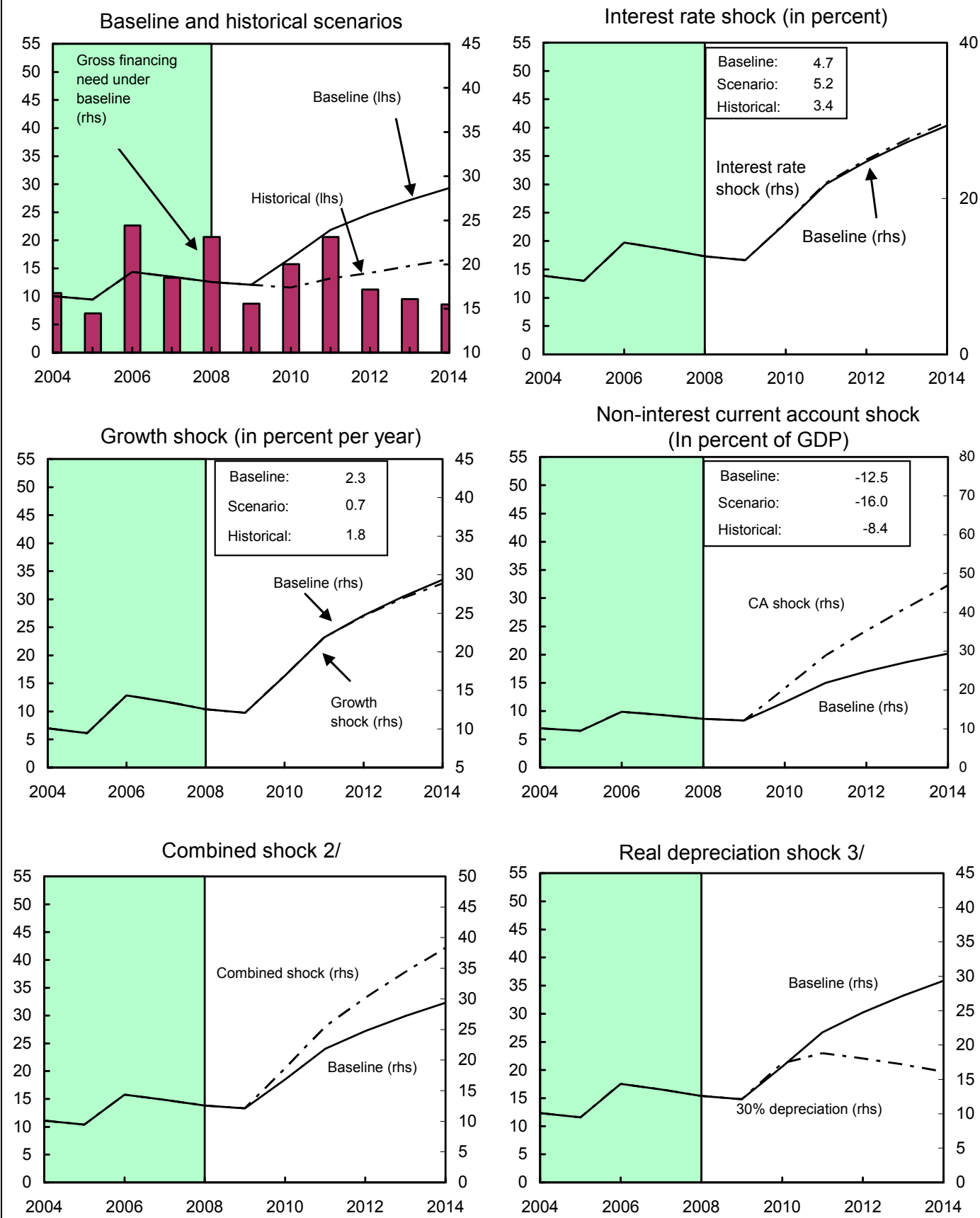

Sources: International Monetary Fund, Country desk data, and Fund staff estimates.

$1 /$ Shaded areas represent actual data. Individual shocks are permanent one-half standard deviation shocks. Figures in the boxes represent average projections for the respective variables in the baseline and scenario being presented. Ten-year historical average for the variable is also shown.

2/ Permanent 1/4 standard deviation shocks applied to real interest rate, growth rate, and current account balance.

3/ One-time real depreciation of 30 percent occurs in 2009. 


\section{E. Exchange Rate Policy}

33. The 20 percent devaluation in April 2009 reduced the degree of overvaluation, which staff now estimates at 0-15 percent (Box 1). However, the exchange rate assessment is complicated by weaknesses in balance of payments data and uncertainties about the size of the external financing gap over the medium term, and how it will be filled.

\section{Staff supported the authorities' intention to move toward a more flexible} exchange rate arrangement. The exchange rate peg to a basket has served as a nominal anchor, but led to a substantial overvaluation by end-2008 because of adverse terms-of-trade shocks. A move toward a more flexible exchange rate will help Fiji absorb external shocks and protect its reserve position. Staff recommended adopting a band of \pm 2 or 3 percent around the current peg and advised that the RBF be given autonomy to widen the band or move the central parity as needed. A shift to a more flexible exchange rate regime would need to be buttressed by tight monetary and fiscal policies, especially in the initial stage.

\section{Some exchange restrictions are subject to Fund approval under Article VIII.}

Restrictions arise from tax certification requirements before foreign companies can remit profits abroad and from limits on large payments (e.g., oil imports and dividends). Staff does not recommend IMF Executive Board approval of these restrictions and advises that they be removed.

\section{F. Structural Reforms}

36. The authorities plan sweeping structural reform to ensure fiscal sustainability, spur growth, and reduce poverty. Their priorities are reforms to the civil service, public enterprises, sugar sector, and land-lease system, together with price liberalization. The AsDB provided advice on civil service and public enterprise reform, and the World Bank on land and sugar sector reform. ${ }^{4}$

37. Fiscal sustainability rests on the implementation of a well-designed and comprehensive civil service reform. Staff supported the authorities' proposed study on right-sizing of government (Box 2). Staff noted that actions to identify non-core service areas that can be corporatized, privatized or outsourced should be continued.

\footnotetext{
${ }^{4}$ The AsDB and the World Bank have no concrete plans to lend to Fiji at this stage.
} 
BoX 1. FIJI: EQUILIBRIUM REAL EFFECTIVE EXCHANGE RATE

The April 2009 devaluation reduced the degree of overvaluation. Standard approaches suggest the currency is overvalued by $0-15$ percent, as the current account deficit is projected to remain high over the medium term. Current account projections assume regularization of dividend payments (US\$180 million) presently subject to exchange control.

\section{The macroeconomic balance} approach suggests an equilibrium current account deficit of 7 percent of GDP, implying an 11 percent overvaluation. Also, a rough application of the external sustainability approach shows a 13 percent overvaluation.

The ERER approach suggests that the exchange rate is in line with

fundamentals. This assumes a further decline in the terms of trade and a real depreciation of 12-13 percent after the exchange rate pass-through to domestic prices is complete.

The rebound in tourism and foreign reserves since April implies no overvaluation at present. A simple econometric analysis shows that a onepercent real depreciation leads to a 4 percent increase in gross reserves, controlling for external demand (proxied by Australian real income). This suggests that most of the increase in reserves since April (excluding the SDR allocation and FNPF asset repatriation) was due to the devaluation.

\begin{tabular}{|c|c|c|c|}
\hline \multicolumn{4}{|c|}{ Exchange Rate Assessment 1/ } \\
\hline & \multicolumn{2}{|c|}{$\mathrm{CA} / \mathrm{GDP}$} & REER \\
\hline & Norm & Projection 2/ & Overvaluation \\
\hline \multicolumn{4}{|l|}{ MB approach 3/ } \\
\hline Current account balance (CAB) & -7.1 & -11.5 & 10.7 \\
\hline \multicolumn{4}{|l|}{ ERER approach 4/ } \\
\hline Desk & $\ldots$ & $\ldots$ & -0.6 \\
\hline \multicolumn{4}{|l|}{ ES approach 5/ } \\
\hline $\mathrm{CAB}$ including errors and omissions & -5.4 & -10.9 & 13.4 \\
\hline \multicolumn{4}{|l|}{ Source: Fund staff estimates. } \\
\hline \multicolumn{4}{|c|}{$\begin{array}{l}\text { 1/ Results expressed in percent. } \\
\text { 2/ Staff projection of the underlying CA/GDP in } 2014 .\end{array}$} \\
\hline 2/ Staff projection of the underlying $\mathrm{CA}$ & in 2014 & & \\
\hline \multirow{2}{*}{\multicolumn{4}{|c|}{$\begin{array}{l}3 \text { / Based on a semi-elasticity of the CA/GDP with respect to the REER of }-0.41 \text {. } \\
4 \text { / Overvaluation is assessed assuming a } 12-13 \text { percent real depreciation following the April } 2009 \\
\text { devaluation. }\end{array}$}} \\
\hline & & & \\
\hline \multicolumn{4}{|c|}{$\begin{array}{l}\text { 5/ Non-interest current account deficit that stabilizes net foreign liabilities, estimated at } \\
125 \text { percent of GDP in } 2014 \text {. }\end{array}$} \\
\hline
\end{tabular}
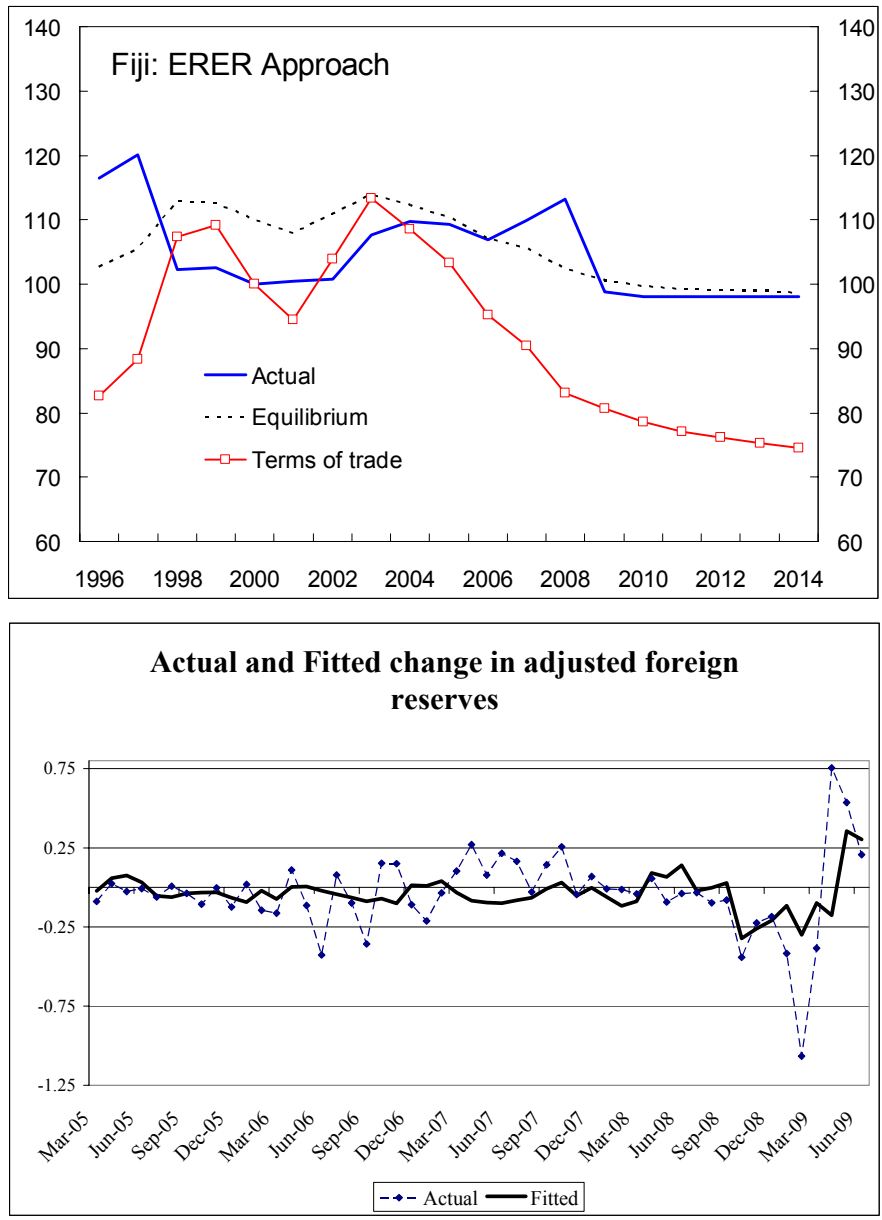


\section{BoX 2. FiJI: Civil SERVICE REFORM}

Spending on wages and salaries for civil servants is relatively high in Fiji. The central government wage bill is over 10 percent of GDP, about the median for Pacific and Caribbean countries, but the share of total spending on wages and salaries (nearly 40 percent) is relatively high. This reflects both high pay rates and the sizable civil service. Civil servants are, on average, paid $3^{1} \frac{1}{2}$ times GDP per capita. While below the average for Pacific countries, this ratio is still high. In addition, the ratio of civil servants to the population is above comparator countries.

\section{The authorities have taken some} steps to reduce the number of civil servants. The retirement age was reduced from 60 to 55 years in mid2009 releasing 2,200 officials (7 percent of civil servants), but 40 percent of these vacancies have already been filled. Water, procurement, and printing services are being corporatized, which will make 1,000 staff redundant.

\section{The authorities are planning a} study on right-sizing government in early 2010. The aim is to reduce the wage bill and increase the efficiency of government services by focusing on core functions, including health and education. Given that these reforms are at the early planning stage, no estimates of the fiscal impact have been made. International experience suggests that these reforms should be comprehensive, with a welldesigned redundancy package and retraining provided to laid-off workers. Moreover, the adoption of performance-based remuneration for civil servants should be a key component.
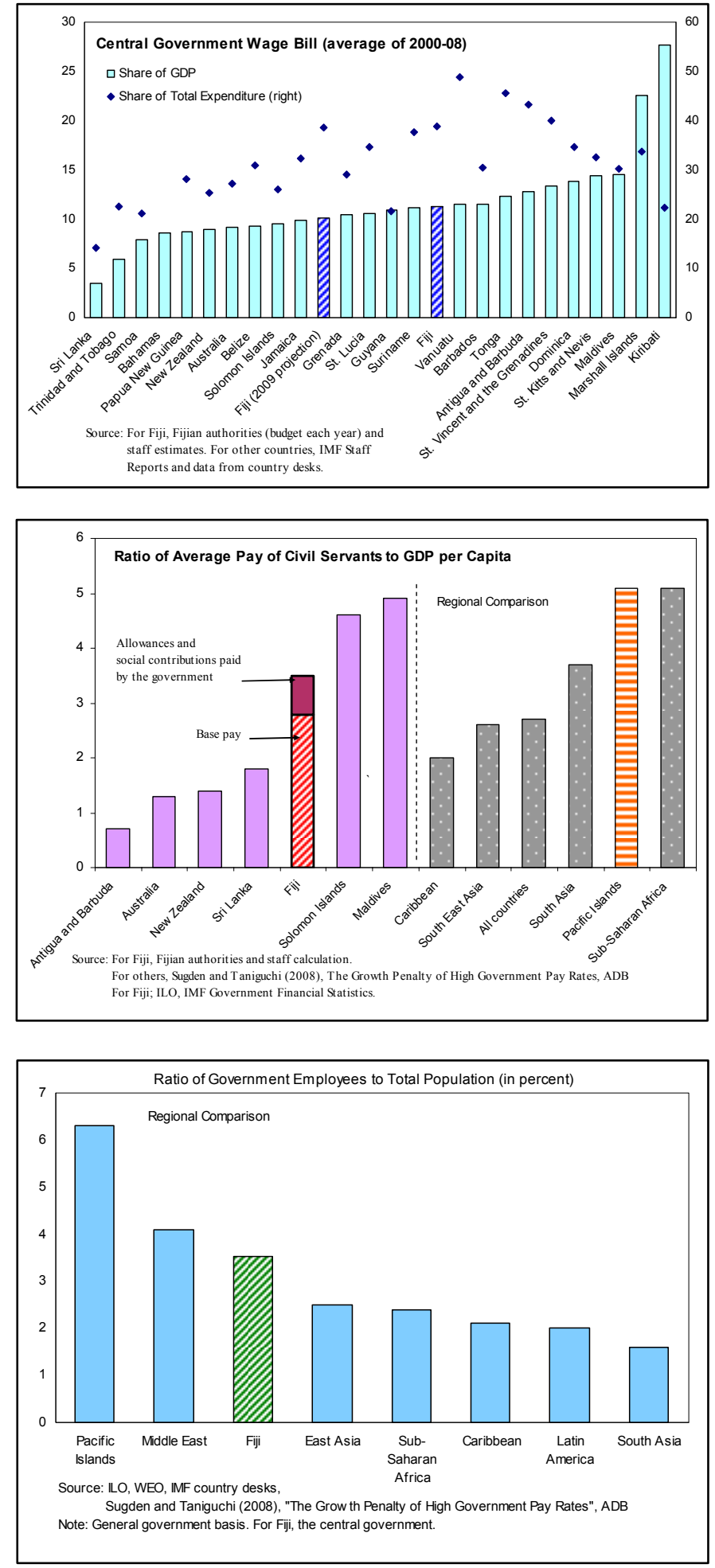
Sugden and Taniguchi (2008), "The Grow th Penally of High Government Pay Rates", ADB Note: General government basis. For Fiji, the central government. 
38. Public enterprises are a source of significant fiscal risk. To eliminate losses and encourage private investment in these areas, tariffs for all goods and services provided by public enterprises should be raised to full cost recovery levels. For example, the Fiji Electricity Authority's tariffs - among the lowest in the region — should be raised to reflect the cost of imported fuel and adjusted over time in line with changes in import costs. Tariff adjustments should be accompanied by well-targeted transfers to protect the poor. The authorities are considering raising tariffs, strengthening oversight of public enterprises, and moving regulatory functions to an independent entity to improve governance.

\section{There is an urgent need to address Fiji Sugar Corporation's (FSC) financial}

difficulties. FSC is an inefficient public sector monopoly that processes sugar and suffered losses equivalent to $3 / 4$ percent of GDP in 2008/09. The authorities are considering a number of options, including privatization. Staff advised that viable sugar mills be privatized to allow for competition, and unviable mills closed. For privatization to be successful the land-lease system must be reformed and contracts between mills and growers should be commercially based.

40. Investment and job creation will be encouraged by land reform. As much as 40 percent of arable land is currently underused due to problems with the administration, pricing and enforceability of leases. This discourages mechanization and the commercial use of land, including as collateral to obtain financing. Increased certainty in land leases will spur development and diversification of agriculture.

41. Staff welcomed steps to liberalize prices, as these controls distort market signals. The authorities recently removed price surveillance over almost 150 items and announced that remaining price controls - mostly on basic food items - would be removed over the next year. The 2010 budget introduced a food voucher program costing 0.1 percent of GDP to help compensate vulnerable groups for price rises.

\section{G. Other}

42. Fiji's macroeconomic statistics are generally adequate for surveillance, but some problems remain. Staff welcomed the recent revisions to the national accounts and balance of payments. However, errors and omissions in the balance of payments remain sizable and GDP expenditure-side data are not publicly available. Moreover, budget reporting lacks transparency and no updates are published during the fiscal year. Staff of the Pacific Financial Technical Assistance Centre is working with the authorities to address the statistical weaknesses.

\section{STAFF APPRAisal}

\section{Economic performance has been weak in recent years due to political} developments, delays in structural reforms, and worsening terms of trade. The economy is expected to contract by $2 \frac{1}{2}$ percent in 2009 but a recovery is likely in 2010 , led by a 
rebound in tourism. Growth over the medium-term should rise to $2^{1 / 2} 2$ percent with fiscal consolidation and progress on structural reforms.

44. Fiji, however, faces considerable downside risks. Excess liquidity in the banking system and high government debt threaten macroeconomic stability. The economic outlook remains highly uncertain because of political developments, volatility of commodity prices, the risk of natural disasters, and the complex structural reform agenda.

45. The authorities are to be commended for their efforts to limit the overall deficit in 2009 to the budgeted level of about 3 percent of GDP. This is being achieved by containing expenditure in the face of an unexpected 10 percent fall in revenue this year, though some spending cuts are not sustainable.

46. Concrete measures are needed to reduce central government debt over the medium term to ensure fiscal sustainability. Limiting the 2010 budget deficit to around 2 percent of GDP - excluding costs associated with civil service reforms - would begin to reduce the debt-to-GDP ratio. For the medium term, the authorities should adhere to their earlier target of reducing central government debt to 45 percent of GDP by 2014. A faster pace of fiscal consolidation would be necessary in the absence of pension reforms at the FNPF. Expenditure can be contained through civil service reform and revenue can be strengthened by rationalizing tax incentives, improving tax administration and raising excise taxes.

47. Monetary policy should be tightened to ensure inflation returns to low levels and protect foreign exchange reserves. The recent increase in the statutory reserve deposit ratio and the removal of ceilings on bank lending rates and spreads are welcome steps, but further measures are needed to absorb excess liquidity.

48. The 20 percent devaluation in April 2009 reduced the degree of overvaluation of the exchange rate, but the external financing gap exceeds US\$500 million for 2010-12. The overvaluation is estimated at $0-15$ percent but is complicated by data weaknesses and uncertainties about the size of the financing gap over the medium term and how it would be filled.

49. Staff recommend a move toward a more flexible exchange rate to help Fiji absorb external shocks and protect its reserve position. A shift to a more flexible exchange rate regime would need to be buttressed by tight monetary and fiscal policies.

50. The Fiji National Provident Fund (FNPF, a public pension fund) should be reformed to make it actuarially sound. The generous rate of conversion of benefits to annuities needs to be reduced and management should be made independent of government and responsible to beneficiaries. The government should also reduce its reliance on FNPF financing. 
51. Recent improvements in bank supervision are welcome but further steps toward risk-based supervision are needed. Stress tests of banks by the RBF show that some smaller banks are vulnerable to adverse shocks. These tests should be reviewed with the banks, and remedial action should be taken if needed, including by raising capital.

\section{Sweeping structural reform is crucial to ensure fiscal sustainability, spur} growth, and create jobs. Reforms to the civil service, public enterprises and land-lease system - together with price liberalization - should help lift potential growth if they are designed well and implemented fully. The social impact of redundancies should be mitigated through retraining and/or voluntary packages.

53. It is recommended that the next Article IV consultation take place on a 12-month cycle. 
Table 1. Fiji: Selected Economic Indicators, 2005-11

Nominal GDP (2008): US\$3,572 million

Population (2008): 843,132

GDP per capita (2008): US $\$ 4,237$

Quota: SDR 70.3 million

\begin{tabular}{|c|c|c|c|c|c|c|c|}
\hline & 2005 & 2006 & 2007 & $\begin{array}{c}2008 \\
\text { Prel. }\end{array}$ & $\begin{array}{r}2009 \\
\text { Est. }\end{array}$ & $\begin{array}{l}2010 \\
\text { Proj. }\end{array}$ & $\begin{array}{l}2011 \\
\text { Proj. }\end{array}$ \\
\hline \multicolumn{8}{|l|}{ Output and prices (percent change) } \\
\hline Real GDP (at constant factor cost) & 0.7 & -0.4 & -1.2 & -0.1 & -2.5 & 2.0 & 2.2 \\
\hline Consumer prices (end of period) & 2.7 & 3.1 & 4.3 & 6.6 & 6.7 & 3.0 & 3.0 \\
\hline \multicolumn{8}{|l|}{ Central government budget (percent of GDP) } \\
\hline Revenue and grants & 24.1 & 26.1 & 25.4 & 24.8 & 23.1 & 23.0 & 23.1 \\
\hline Total expenditure & 27.4 & 29.0 & 27.0 & 25.0 & 26.0 & 26.4 & 25.9 \\
\hline Of which: Capital & 4.2 & 4.0 & 3.2 & 3.7 & 4.5 & 5.1 & 5.1 \\
\hline Overall balance & -3.3 & -3.0 & -1.6 & -0.2 & -2.9 & -3.5 & -2.8 \\
\hline Total debt outstanding & 47.6 & 53.1 & 49.9 & 51.2 & 52.7 & 53.2 & 52.2 \\
\hline \multicolumn{8}{|l|}{ Money and credit (percent change) } \\
\hline Domestic credit & 26.6 & 23.6 & 3.2 & 4.8 & 7.8 & 3.5 & $\ldots$ \\
\hline Government (net) & 55.6 & 28.3 & -15.0 & -38.0 & 63.0 & -11.5 & $\ldots$ \\
\hline Broad money (M2) & 15.0 & 19.8 & 10.4 & -6.9 & 1.9 & 4.8 & $\ldots$ \\
\hline Reserve money & 2.2 & 24.3 & 37.4 & -30.0 & 30.8 & 3.9 & $\ldots$ \\
\hline Treasury bill rate (91-day) $1 /$ & 2.1 & 10.9 & 0.3 & 0.5 & 7.0 & $\ldots$ & $\ldots$ \\
\hline Commercial bank lending rate $1 /$ & 6.7 & 7.9 & 8.5 & 7.7 & 7.7 & $\ldots$ & $\ldots$ \\
\hline \multicolumn{8}{|l|}{ External sector (in millions of U.S. dollars) } \\
\hline Trade balance & -719 & -897 & -842 & $-1,108$ & -714 & -812 & -856 \\
\hline (In percent of GDP) & -23.9 & -28.9 & -24.7 & -31.0 & -22.9 & -26.4 & -26.5 \\
\hline Exports, f.o.b. & 742 & 729 & 787 & 944 & 637 & 673 & 697 \\
\hline Imports, f.o.b. & 1,462 & 1,626 & 1,629 & 2,052 & 1,351 & 1,485 & 1,553 \\
\hline Net nonfactor services and transfers & 468 & 436 & 464 & 496 & 413 & 436 & 473 \\
\hline Net factor income & -46 & -120 & -84 & -28 & 4 & -116 & -86 \\
\hline Current account balance & -298 & -582 & -463 & -640 & -297 & -493 & -469 \\
\hline (In percent of GDP) & -9.9 & -18.7 & -13.6 & -17.9 & -9.5 & -16.0 & -14.5 \\
\hline Capital/financial account balance & 116 & 781 & 437 & 258 & 418 & 290 & 151 \\
\hline Government bond & $\ldots$ & 150 & & $\ldots$ & $\ldots$ & $\ldots$ & -150 \\
\hline Errors and omissions & 19 & -53 & 117 & 212 & 98 & 47 & 50 \\
\hline Overall balance & -163 & 145 & 91 & -169 & 219 & -156 & -269 \\
\hline Gross official reserves (in millions of U.S. dollars) & 315 & 460 & 551 & 381 & 600 & 561 & 584 \\
\hline (In months of retained imports) & 1.9 & 2.9 & 2.7 & 2.5 & 3.9 & 3.5 & 3.5 \\
\hline External central government debt (millions of U.S. dollars) & 94 & 250 & 256 & 270 & 240 & 255 & 297 \\
\hline (In percent of GDP) & 3.2 & 7.8 & 7.2 & 8.4 & 8.3 & 8.3 & 9.2 \\
\hline \multicolumn{8}{|l|}{ Miscellaneous } \\
\hline Real effective rate (average) & 109.2 & 106.9 & 109.9 & 114.4 & $90.22 /$ & & \\
\hline Exchange rate (Fiji dollars per U.S. dollar; end of period) & 1.74 & 1.66 & 1.55 & 1.76 & 2.07 & 2.07 & 2.07 \\
\hline GDP at current market prices (in millions of Fiji dollars) & 5,084 & 5,372 & 5,483 & 5,694 & 5,993 & 6,356 & 6,693 \\
\hline Oil price (U.S. dollars per barrel) & 53.4 & 64.3 & 71.1 & 97.0 & 61.5 & 76.5 & 79.5 \\
\hline
\end{tabular}

Sources: Reserve Bank of Fiji; Ministry of Finance and National Planning; and Fund staff estimates.

$1 /$ For 2009, interest rates as of August.

2/ June 2009 (2000 REER = 100). 
Table 2. Fiji: Central Government Finances, 2005-11

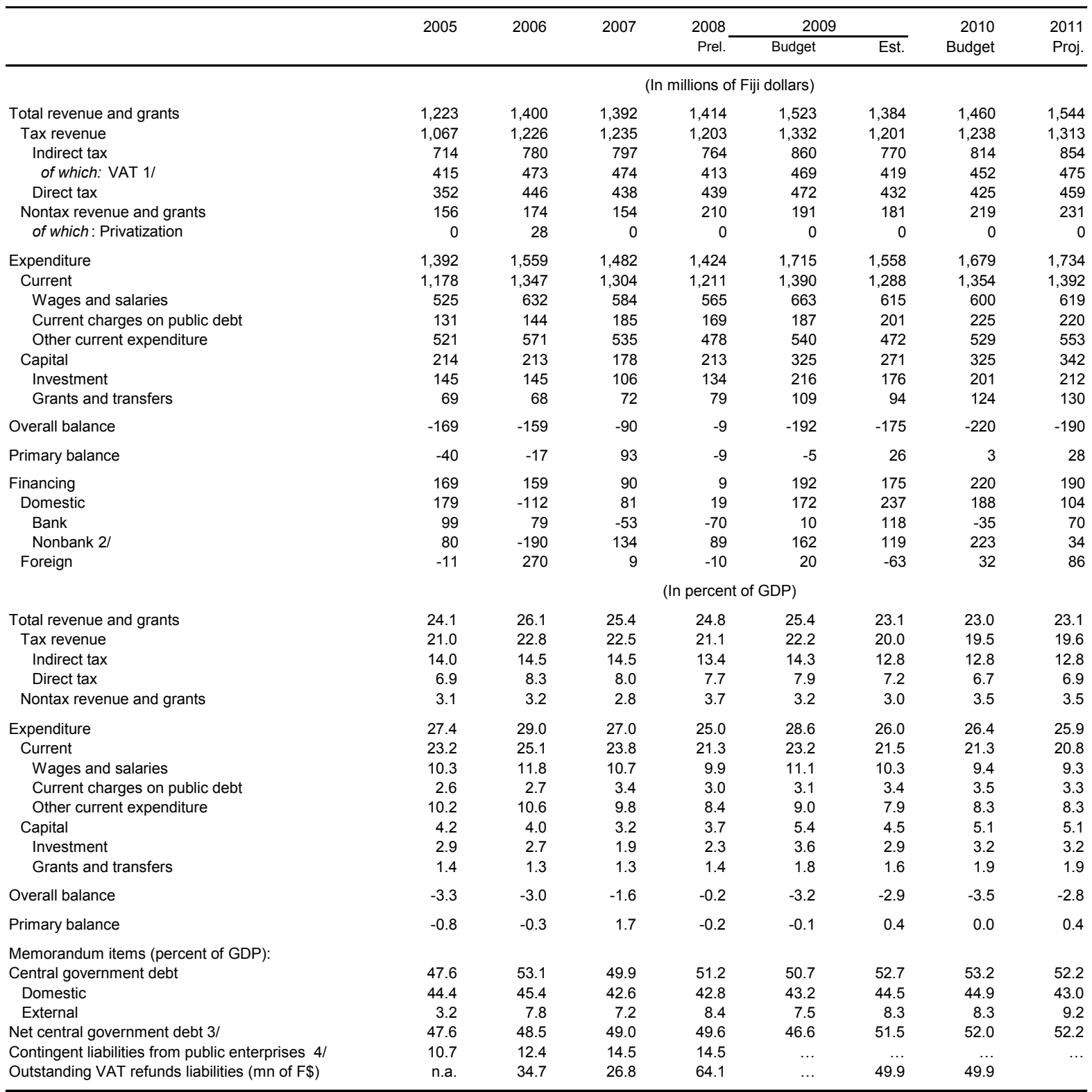

Sources: Ministry of Finance and National Planning; and Fund staff estimates.

$1 /$ Net of accumulation (reduction) of VAT refund arrears in the period. Zero accumulation of arrears assumed for 2009 and 2010 budgets. 2/ From 2007 onwards, it includes accumulation (reduction) of VAT refund arrears in the period.

$3 /$ Net of deposits in JP Morgan.

4/ Debt guaranteed by the government, excluding FNPF liabilities. 
Table 3. Fij: Monetary Survey, 2005-10

\begin{tabular}{|c|c|c|c|c|c|c|}
\hline & 2005 & 2006 & 2007 & 2008 & $\begin{array}{r}2009 \\
\text { Est. }\end{array}$ & $\begin{array}{l}2010 \\
\text { Proj. }\end{array}$ \\
\hline \multicolumn{7}{|c|}{ (In millions of Fiji dollars) } \\
\hline Net foreign assets & 753 & 806 & 884 & 466 & 1,066 & 960 \\
\hline Monetary authority & 823 & 880 & 957 & 559 & 1,166 & 1,085 \\
\hline Depository Monetary banks & -70 & -74 & -73 & -92 & -100 & -125 \\
\hline Domestic credit & 2,369 & 2,928 & 3,020 & 3,166 & 3,414 & 3,532 \\
\hline Claims on government (net) & 278 & 356 & 303 & 188 & 306 & 271 \\
\hline Claims on official entities & 142 & 160 & 238 & 221 & 240 & 250 \\
\hline Claims on private sector & 1,949 & 2,411 & 2,479 & 2,757 & 2,867 & 3,011 \\
\hline Broad money (M2) & 2,514 & 3,012 & 3,326 & 3,098 & 3,156 & 3,307 \\
\hline Narrow money (M1) & 1,197 & 1,142 & 1,639 & 1,300 & 1,217 & 1,271 \\
\hline Of which: Currency outside banks & 280 & 294 & 290 & 315 & 330 & 340 \\
\hline Quasi-money & 1,317 & 1,870 & 1,687 & 1,798 & 1,939 & 2,036 \\
\hline Other items (net) & 557 & 721 & 579 & 535 & 1,324 & 1,185 \\
\hline \multirow[t]{2}{*}{ Reserve money } & 531 & 660 & 908 & 635 & 830 & 863 \\
\hline & \multicolumn{4}{|c|}{ (12-month percent change) } & & \\
\hline Domestic credit & 26.6 & 23.6 & 3.2 & 4.8 & 7.8 & 3.5 \\
\hline Claims on government (net) & 55.6 & 28.3 & -15.0 & -38.0 & 63.0 & -11.5 \\
\hline Claims on official entities & 11.5 & 12.7 & 48.8 & -7.0 & 8.4 & 4.2 \\
\hline Claims on private sector & 24.5 & 23.7 & 2.8 & 11.2 & 4.0 & 5.0 \\
\hline Broad money (M2) & 15.0 & 19.8 & 10.4 & -6.9 & 1.9 & 4.8 \\
\hline Narrow money (M1) & 17.6 & -4.6 & 43.5 & -20.7 & -6.4 & 4.5 \\
\hline Quasi-money & 12.8 & 42.0 & -9.8 & 6.6 & 7.9 & 5.0 \\
\hline \multirow[t]{2}{*}{ Reserve money } & 2.2 & 24.3 & 37.4 & -30.0 & 30.8 & 3.9 \\
\hline & \multicolumn{5}{|c|}{ (12-month change as a percent of $\mathrm{M} 2$ at beginning of period) } & \\
\hline Net foreign assets & -11.8 & 2.1 & 2.6 & -12.6 & 19.4 & -3.4 \\
\hline Domestic credit & 22.8 & 22.2 & 3.1 & 4.4 & 8.0 & 3.7 \\
\hline Claims on government (net) & 4.5 & 3.1 & -1.8 & -3.5 & 3.8 & -1.1 \\
\hline Claims on official entities & 0.0 & 0.0 & 0.0 & -0.5 & 0.6 & 0.3 \\
\hline Claims on private sector & 17.5 & 18.4 & 2.2 & 8.4 & 3.6 & 4.5 \\
\hline Memorandum items: & & units in & ted) & & & \\
\hline Money velocity (M2) $1 /$ & 2.1 & 1.9 & 1.7 & 1.8 & 1.9 & 2.0 \\
\hline Money multiplier (M2) 2/ & 4.7 & 4.6 & 3.7 & 4.9 & 3.8 & 3.8 \\
\hline Claims on the private sector to GDP (percent) & 38 & 45 & 45 & 48 & 48 & 47 \\
\hline \multicolumn{7}{|l|}{ Interest rates (in percent, end of period) } \\
\hline 91-day Treasury bill rate & 2.1 & 10.9 & 0.3 & 0.5 & 7.0 & $\ldots$ \\
\hline Savings deposit & 0.4 & 0.8 & 0.8 & 0.6 & 0.8 & $\ldots$ \\
\hline Commercial bank lending rates $3 /$ & 6.7 & 7.9 & 8.6 & 7.7 & 7.7 & $\ldots$ \\
\hline \multicolumn{7}{|l|}{ Memorandum item } \\
\hline $\begin{array}{l}\text { Claims on private sector (including FNPF loans) } 4 / \\
\text { (12-month percent change) }\end{array}$ & n.a. & n.a. & n.a. & 17.6 & 7.3 & $\ldots$ \\
\hline
\end{tabular}

Sources: IMF, Economic Information System; Reserve Bank of Fiji, Quarterly Review; and Fund staff estimates.

1/ Ratio of GDP to average M2.

2/ Ratio of M2 to reserve money.

3/ Weighted average rate charged by commercial banks on loans.

4/ Assuming FNPF loans in December 2009 remain at the level as of October 2009 at the end of the year. 
Table 4. Fiji: Balance of Payments, 2007-14

\begin{tabular}{|c|c|c|c|c|c|c|c|c|c|c|}
\hline & 2005 & 2006 & 2007 & 2008 & $\begin{array}{r}2009 \\
\text { Est. }\end{array}$ & $\begin{array}{l}2010 \\
\text { Proj. }\end{array}$ & $\begin{array}{c}2011 \\
\text { Proj. }\end{array}$ & $\begin{array}{l}2012 \\
\text { Proj. }\end{array}$ & $\begin{array}{l}2013 \\
\text { Proj. }\end{array}$ & $\begin{array}{r}2014 \\
\text { Proj. }\end{array}$ \\
\hline & \multicolumn{10}{|c|}{ (In millions of US dollars) } \\
\hline Trade balance & -719 & -897 & -842 & $-1,108$ & -714 & -812 & -856 & -888 & -922 & -953 \\
\hline Exports, f.o.b. & 742 & 729 & 787 & 944 & 637 & 673 & 697 & 732 & 768 & 807 \\
\hline Of which: Sugar $1 /$ & 132 & 124 & 115 & 156 & 87 & 76 & 68 & 74 & 81 & 87 \\
\hline Reexports & 204 & 212 & 237 & 306 & 171 & 199 & 216 & 231 & 248 & 266 \\
\hline Other exports & 406 & 393 & 436 & 482 & 379 & 397 & 413 & 427 & 439 & 453 \\
\hline Imports, f.o.b. & 1,462 & 1,626 & 1,629 & 2,052 & 1,351 & 1485 & 1553 & 1621 & 1690 & 1760 \\
\hline Of which: Retained imports (excluding fuels) & 965 & 999 & 985 & 1,245 & 912 & 936 & 957 & 984 & 1,004 & 1,025 \\
\hline Mineral fuels for domestic consumption & 323 & 447 & 443 & 547 & 294 & 380 & 412 & 441 & 474 & 509 \\
\hline limports for re-exports & 173 & 180 & 201 & 260 & 146 & 169 & 183 & 196 & 211 & 226 \\
\hline Services and income, net & 304 & 179 & 254 & 355 & 292 & 181 & 239 & 279 & 309 & 321 \\
\hline Nonfactor services (net) & 350 & 299 & 338 & 383 & 288 & 298 & 326 & 332 & 363 & 372 \\
\hline Of which: Tourism credit & 439 & 433 & 434 & 483 & 368 & 406 & 431 & 457 & 486 & 515 \\
\hline Factor income (net) $2 /$ & -46 & -120 & -84 & -28 & 4 & -116 & -86 & -53 & -54 & -51 \\
\hline Transfers (net) & 117 & 137 & 125 & 113 & 125 & 138 & 147 & 162 & 180 & 194 \\
\hline Private & 69 & 80 & 83 & 34 & 76 & 83 & 91 & 105 & 120 & 138 \\
\hline Of which: Workers' remittances & 135 & 145 & 115 & 72 & 104 & 112 & 121 & 134 & 150 & 168 \\
\hline Official & 48 & 56 & 43 & 79 & 49 & 55 & 57 & 57 & 59 & 55 \\
\hline Current account & -298 & -582 & -463 & -640 & -297 & -493 & -469 & -447 & -433 & -439 \\
\hline Capital account (net) & 8 & 0 & 13 & 16 & 10 & 13 & 13 & 0 & 0 & 0 \\
\hline Financial account (net) & 108 & 781 & 423 & 242 & 408 & 277 & 138 & 306 & 280 & 291 \\
\hline FDI (net) & 150 & 415 & 329 & 313 & 263 & 264 & 261 & 273 & 273 & 277 \\
\hline Net loans to the government & -2 & 148 & 102 & -6 & -48 & 16 & -109 & 16 & -1 & -5 \\
\hline Other investment (net) $3 /$ & -39 & 219 & -8 & -65 & 192 & -3 & -15 & 18 & 8 & 20 \\
\hline Of which: FNPF redemption/(- investment) & -14 & 147 & 3 & 15 & 29 & -15 & -15 & -15 & -15 & -15 \\
\hline Errors and omissions & 19 & -53 & 117 & 212 & 98 & 47 & 50 & 50 & 50 & 50 \\
\hline Overall balance & -163 & 145 & 91 & -169 & 219 & -156 & -269 & -91 & -103 & -97 \\
\hline \multirow[t]{2}{*}{ Financing gap } & & & & & & 117 & 292 & 114 & 126 & 123 \\
\hline & \multicolumn{10}{|c|}{ (In percent of GDP) } \\
\hline Trade balance & -23.9 & -28.9 & -24.7 & -31.0 & -22.9 & -26.4 & -26.5 & -26.0 & -25.6 & -25.1 \\
\hline Current account balance & -9.9 & -18.7 & -13.6 & -17.9 & -9.5 & -16.0 & -14.5 & -13.1 & -12.0 & -11.5 \\
\hline Capital/financial account & 3.8 & 25.2 & 12.8 & 7.2 & 13.4 & 9.4 & 4.7 & 9.0 & 7.8 & 7.7 \\
\hline Overall balance & -5.4 & 4.7 & 2.7 & -4.7 & 7.0 & -5.1 & -8.3 & -2.7 & -2.9 & -2.6 \\
\hline \multicolumn{11}{|c|}{ (Annual growth) } \\
\hline Tourism receipts & 4.5 & -1.2 & 0.2 & 11.2 & -23.7 & 10.1 & 6.3 & 6.1 & 6.1 & 6.1 \\
\hline Workers' remittances & 221.7 & 7.5 & -20.5 & -37.5 & 44.9 & 8.0 & 8.0 & 10.0 & 12.0 & 12.0 \\
\hline Imports of goods and services & 12.3 & 9.1 & 0.0 & 23.6 & -30.9 & 9.9 & 4.6 & 4.4 & 4.2 & 4.1 \\
\hline Oil prices & 41.3 & 20.5 & 10.7 & 36.4 & -36.6 & 24.3 & 3.9 & 1.9 & 2.5 & 2.1 \\
\hline \multicolumn{11}{|l|}{ Memorandum items: } \\
\hline External debt (in millions of U.S. dollars) & 285 & 445 & 461 & 449 & 378 & 517 & 706 & 844 & 979 & 1117 \\
\hline External debt over GDP 4/ & 9.5 & 14.4 & 13.5 & 12.6 & 12.1 & 16.9 & 21.8 & 24.7 & 27.2 & 29.4 \\
\hline External central government debt (in mn U.S. dollars) & 94 & 250 & 256 & 270 & 240 & 255 & 297 & 313 & 312 & 307 \\
\hline External central government debt over GDP & 3.1 & 8.1 & 7.5 & 7.6 & 7.7 & 8.3 & 9.2 & 9.2 & 8.6 & 8.1 \\
\hline Central government debt-service ratio 5 / & 1.1 & 1.4 & 2.4 & 1.8 & 5.2 & 2.4 & 22.6 & 5.5 & 6.4 & 7.3 \\
\hline Gross official reserves (in millions of U.S. dollars) $6 /$ & 315 & 460 & 551 & 381 & 600 & 561 & 584 & 607 & 630 & 656 \\
\hline (In months of retained GNFS imports) & 1.9 & 2.9 & 2.6 & 2.6 & 3.8 & 3.5 & 3.5 & 3.5 & 3.5 & 3.5 \\
\hline GDP (in millions of U.S. dollars) & 3,007 & 3,103 & 3,405 & 3,572 & 3,120 & 3,071 & 3,233 & 3,412 & 3,603 & 3,805 \\
\hline Trading partners' real GDP growth & 3.4 & 2.8 & 2.6 & 1.6 & -1.9 & 1.5 & 2.6 & 2.8 & 2.7 & 2.6 \\
\hline Trading partners' import volume (goods and services) & 8.6 & 4.9 & 4.5 & 3.0 & -11.9 & 3.1 & 4.8 & 5.1 & 4.9 & 5.5 \\
\hline Oil price (U.S. dollars per barrel) & 53.4 & 64.3 & 71.1 & 97.0 & 61.5 & 76.5 & 79.5 & 81.0 & 83.0 & 84.8 \\
\hline
\end{tabular}

Sources: Fiji Islands Bureau of Statistics; Reserve Bank of Fiji; and Fund staff estimates.

1/ Including EU sugar transfer payments.

2/ It includes repatriation of foreign companies' accumulated dividends of US $\$ 80$ million in 2010 and US $\$ 40$ million in 2011 $3 /$ In 2009, it includes Fiji's share in the General and Special SDR allocation (SDR 60.2 million).

4 / Includes gap financing.

$5 /$ In percent of exports of goods and nonfactor services.

6/ It includes government's U.S. dollar deposits held with JP Morgan set aside to repay the government bond issued in September 2006. 
Table 5. Fiji: Selected Medium-Term Indicators, 2007-14

\begin{tabular}{|c|c|c|c|c|c|c|c|c|}
\hline & \multirow[t]{2}{*}{2007} & \multirow{2}{*}{$\begin{array}{c}2008 \\
\text { Prel. }\end{array}$} & 2009 & 2010 & 2011 & 2012 & 2013 & 2014 \\
\hline & & & \multicolumn{6}{|c|}{ Projections } \\
\hline \multicolumn{9}{|l|}{ Output and prices (percent change) } \\
\hline Real GDP (at constant factor cost) & -1.2 & -0.1 & -2.5 & 2.0 & 2.2 & 2.5 & 2.5 & 2.5 \\
\hline Consumer prices (average) & 4.8 & 7.8 & 4.0 & 4.0 & 3.0 & 3.0 & 3.0 & 3.0 \\
\hline \multicolumn{9}{|l|}{ Savings and investment $1 /$} \\
\hline National savings & 1.6 & -2.9 & 4.5 & -1.0 & 1.5 & 3.9 & 5.5 & 7.0 \\
\hline Public & 1.6 & 3.6 & 1.6 & 1.7 & 2.3 & 2.7 & 3.0 & 3.3 \\
\hline Private & 0.0 & -6.5 & 2.9 & -2.7 & -0.8 & 1.2 & 2.5 & 3.6 \\
\hline Gross investment & 15.2 & 15.0 & 14.0 & 15.0 & 16.0 & 17.0 & 17.5 & 18.5 \\
\hline Public & 3.2 & 3.7 & 4.5 & 5.1 & 5.1 & 5.1 & 5.1 & 5.1 \\
\hline Private & 12.0 & 11.3 & 9.5 & 9.9 & 10.9 & 11.9 & 12.4 & 13.4 \\
\hline Foreign savings & 13.6 & 17.9 & 9.5 & 16.0 & 14.5 & 13.1 & 12.0 & 11.5 \\
\hline \multicolumn{9}{|l|}{ Central government budget (in percent of GDP) } \\
\hline Total revenue and grants (excl. privatization) & 25.4 & 24.8 & 23.1 & 23.0 & 23.1 & 23.2 & 23.4 & 23.6 \\
\hline Total expenditure and net lending & 27.0 & 25.0 & 26.0 & 26.4 & 25.9 & 25.6 & 25.5 & 25.4 \\
\hline Capital expenditure & 3.2 & 3.7 & 4.5 & 5.1 & 5.1 & 5.1 & 5.1 & 5.1 \\
\hline (As a percent of total expenditure) & 12.0 & 14.9 & 17.4 & 19.4 & 19.7 & 19.9 & 20.0 & 20.2 \\
\hline Current expenditure & 23.8 & 21.3 & 21.5 & 21.3 & 20.8 & 20.5 & 20.4 & 20.3 \\
\hline Of which: Wages and salaries & 10.7 & 9.9 & 10.3 & 9.4 & 9.3 & 9.1 & 8.9 & 8.7 \\
\hline Interest & 3.4 & 3.0 & 3.4 & 3.5 & 3.3 & 3.3 & 3.4 & 3.5 \\
\hline Other & 9.8 & 8.4 & 7.9 & 8.3 & 8.3 & 8.2 & 8.1 & 8.1 \\
\hline Overall balance & -1.6 & -0.2 & -2.9 & -3.5 & -2.8 & -2.4 & -2.1 & -1.8 \\
\hline Primary balance & 1.7 & -0.2 & 0.4 & 0.0 & 0.4 & 0.8 & 1.2 & 1.7 \\
\hline Central Government debt outstanding & 49.9 & 51.2 & 52.7 & 53.2 & 52.2 & 51.9 & 51.3 & 50.3 \\
\hline \multicolumn{9}{|l|}{ Balance of payments (in percent of GDP) } \\
\hline Trade balance & -24.7 & -31.0 & -22.9 & -26.4 & -26.5 & -26.0 & -25.6 & -25.1 \\
\hline Services plus income (net) & 7.5 & 9.9 & 9.4 & 5.9 & 7.4 & 8.2 & 8.6 & 8.4 \\
\hline Transfers (net) & 3.7 & 3.2 & 4.0 & 4.5 & 4.6 & 4.7 & 5.0 & 5.1 \\
\hline Current account balance & -13.6 & -17.9 & -9.5 & -16.0 & -14.5 & -13.1 & -12.0 & -11.5 \\
\hline Capital/financial account balance & 12.8 & 7.2 & 13.4 & 9.4 & 4.7 & 9.0 & 7.8 & 7.7 \\
\hline Of which: FDI (net) & 9.7 & 8.8 & 8.4 & 8.6 & 8.1 & 8.0 & 7.6 & 7.3 \\
\hline Of which: portfolio investment (net) & 0.0 & -1.3 & 0.4 & -0.4 & -0.5 & -0.1 & -0.3 & -0.2 \\
\hline Of which: other investment (net) & 2.8 & -0.7 & 4.2 & 0.8 & -3.4 & 1.1 & 0.5 & 0.6 \\
\hline Errors and omissions & 3.4 & 5.9 & 3.1 & 1.5 & 1.5 & 1.5 & 1.4 & 1.3 \\
\hline Overall balance & 2.7 & -4.7 & 7.0 & -5.1 & -8.3 & -2.7 & -2.9 & -2.6 \\
\hline External central government debt $2 /$ & 7.2 & 8.4 & 8.3 & 12.1 & 17.2 & 20.1 & 22.5 & 24.4 \\
\hline \multicolumn{9}{|l|}{ Memorandum items: } \\
\hline Gross official reserves (US\$ mn.) 3/ & 551 & 381 & 600 & 561 & 584 & 607 & 630 & 656 \\
\hline (In months of retained imports) 4 / & 2.7 & 2.5 & 3.9 & 3.5 & 3.5 & 3.5 & 3.5 & 3.5 \\
\hline
\end{tabular}

Sources: Reserve Bank of Fiji; Ministry of Finance and National Planning; and Fund staff estimates.

1/ Saving-investment balances are not available and are estimated by staff. Foreign savings is equivalent to the current account deficit, with private savings as a residual.

2/ Includes gap financing.

$3 /$ Including the balance of the September 2006 international bond issuance.

4/ Imports of goods, f.o.b., and nonfactor services. 
Table 6. Status of Key 2004 Fiscal ROSC Recommendations

\begin{tabular}{|c|c|}
\hline 2004 ROSC & Status \\
\hline $\begin{array}{l}\text { Clarify the status of the suspended } 1999 \text { Public } \\
\text { Finance Management Law. }\end{array}$ & $\begin{array}{l}\text { The } 1999 \text { law was replaced by the new } 2004 \\
\text { Financial Management Act (the } 2004 \text { FMA) and } \\
\text { other instructions, providing a legislative framework } \\
\text { to support financial management reform, which } \\
\text { envisages performance budgeting, moving to actual } \\
\text { accounting over the medium term, and introducing a } \\
\text { new financial management information system } \\
\text { (IFMIS). }\end{array}$ \\
\hline $\begin{array}{l}\text { Address weaknesses in compliance of legal and } \\
\text { regulatory requirements on budget implementation. }\end{array}$ & $\begin{array}{l}\text { Compliance remains weak. A draft on accounting } \\
\text { protocols has been prepared. }\end{array}$ \\
\hline $\begin{array}{l}\text { Simplify tax statutes, in particular, the Income Tax } \\
\text { Act, narrowing the room for administrative } \\
\text { discretion. }\end{array}$ & $\begin{array}{l}\text { The new Tax Administrative Decree (effective } \\
\text { January 1, 2010) harmonizes and simplifies } \\
\text { administrative provisions in Income Tax Act, VAT } \\
\text { Decree, Hotel Turnover Tax, Gambling Turnover } \\
\text { Tax, and Land Sales Act. However, there is still room } \\
\text { for discretional administrative decisions. }\end{array}$ \\
\hline $\begin{array}{l}\text { Strengthen the policy framework for publicly- } \\
\text { controlled financial institutions, such as FNPF, Fiji } \\
\text { Development Bank, and the Housing Authority. } \\
\text { Monitor the soundness of their financial positions. }\end{array}$ & $\begin{array}{l}\text { Financial reports are prepared quarterly by the } \\
\text { Ministry of Public Enterprises and annual audited } \\
\text { financial reports are submitted to the Cabinet. } \\
\text { However, oversight is not harmonized, with the } \\
\text { Ministry of Public Enterprises overseeing some } \\
\text { public enterprises, while the Ministry of Finance } \\
\text { oversees the Fiji Development Bank. }\end{array}$ \\
\hline $\begin{array}{l}\text { Establish sound internal controls within ministries, } \\
\text { departments, and Fiji Islands Revenue and } \\
\text { Customs Authority (FIRCA), by: (i) upgrading the } \\
\text { capability of the current accounting system, } \\
\text { (ii) conducting basic reconciliation processes, } \\
\text { (iii) taking effective and timely disciplinary action } \\
\text { for contravention. }\end{array}$ & $\begin{array}{l}\text { Not yet fully enforced. } \\
\text { (i) An Integrated Financial Management Information } \\
\text { System has been partly implemented (four ministries, } \\
\text { including the Ministry of Health, are yet to adopt it). } \\
\text { (ii) The reconciliation process is neither effective nor } \\
\text { timely. (iii) Disciplinary action is not taken in most } \\
\text { cases. Instructions are being reviewed to introduce } \\
\text { disciplinary measures for noncompliance. }\end{array}$ \\
\hline $\begin{array}{l}\text { Introduce an internal audit unit and strengthen } \\
\text { FIRCA's Internal Audit Committee. }\end{array}$ & Internal audit was introduced in 2008. \\
\hline Strengthen audit capacity. & $\begin{array}{l}\text { External Audit has been strengthened in the last few } \\
\text { years. }\end{array}$ \\
\hline $\begin{array}{l}\text { Improve the quality and expand the scope of the } \\
\text { information provided in the annual budget } \\
\text { documents, in accordance with the GFS. }\end{array}$ & $\begin{array}{l}\text { Public agencies and expenditures that are outside the } \\
\text { budget should be included, for example FIRCA, the } \\
\text { Housing Authority, and some large infrastructure } \\
\text { projects. In addition, some expenditure items are } \\
\text { misclassified, e.g., some capital transfers should be } \\
\text { reclassified as current transfers. }\end{array}$ \\
\hline $\begin{array}{l}\text { Introduce quarterly reporting by MOF on the fiscal } \\
\text { outturn and present a mid-year report on budget } \\
\text { implementation to parliament, including revised } \\
\text { spending and revenue forecasts. }\end{array}$ & $\begin{array}{l}\text { Quarterly information on revenue is published, but } \\
\text { no quarterly information on expenditure is available. } \\
\text { Internal monthly revenue and expenditure reports are } \\
\text { available for some areas. The quality of reporting } \\
\text { needs to be improved. }\end{array}$ \\
\hline
\end{tabular}


Table 7. Status of Key FAD Recommendations on Tax Policy and Administration

\begin{tabular}{|c|c|}
\hline 2009 TA on Tax Incentives & Status \\
\hline $\begin{array}{l}\text { Reduce the corporate tax rate to } 25 \\
\text { percent in } 2012 .\end{array}$ & $\begin{array}{l}\text { The corporate income tax rate was reduced from } 31 \text { percent in } \\
2008 \text { to } 28 \text { percent in } 2010 \text { and } 20 \text { percent for companies listed } \\
\text { on the South Pacific Stock Exchange with more than } 40 \text { percent } \\
\text { local equity shareholding. No further CIT rate cuts are currently } \\
\text { planned, as streamlining of incentives has not been put in place. }\end{array}$ \\
\hline $\begin{array}{l}\text { Eliminate the provision of tax holidays } \\
\text { as of December } 31,2011 .\end{array}$ & $\begin{array}{l}\text { Tax holidays have not been eliminated. However, no new tax } \\
\text { holidays were introduced in the } 2010 \text { Budget. }\end{array}$ \\
\hline $\begin{array}{l}\text { Restructure investment allowances by } \\
\text { replacing by, say, a } 20 \text { percent } \\
\text { investment allowance and providing a } \\
\text { higher, say, a } 30 \text { percent allowance for } \\
\text { key priority areas in } 2012 \text {. }\end{array}$ & The 2009 Budget extended periods of some allowances. \\
\hline $\begin{array}{l}\text { Eliminate most sector-specific and } \\
\text { employment-related incentives. }\end{array}$ & $\begin{array}{l}\text { The employment tax reduction scheme was extended to end } \\
2010 .\end{array}$ \\
\hline $\begin{array}{l}\text { Eliminate discretion of the Minister of } \\
\text { Finance to provide ad hoc tariff } \\
\text { concessions. }\end{array}$ & $\begin{array}{l}\text { Discretionary provisions under the Customs Tariff Act have } \\
\text { been maintained. Ad hoc tariff exemptions have been } \\
\text { temporarily suspended by the Minister. }\end{array}$ \\
\hline $\begin{array}{l}\text { Undertake a consultative process to } \\
\text { assess the tax system for the } \\
\text { development of the Northern Region. }\end{array}$ & $\begin{array}{l}\text { The } 2009 \text { Budget sets up a Tax Free Region in the Northern } \\
\text { Region. A consultative process was undertaken with the private } \\
\text { sector and shareholders to review the incentives during the } \\
\text { Economic Summit held in Suva this year. The Fiji Trade and } \\
\text { Investment Board has set up an office in the region and has close } \\
\text { dialogue with the business and the authorities. }\end{array}$ \\
\hline $\begin{array}{l}2008 \text { TA on Tax } \\
\text { Administration }\end{array}$ & Status \\
\hline $\begin{array}{l}\text { Reorganize core tax and customs } \\
\text { functions of the Fiji Islands Revenue } \\
\text { and Customs Authority (FIRCA). }\end{array}$ & \multirow{3}{*}{$\begin{array}{l}\text { Early in 2009, FIRCA formed the Reform Steering Committee } \\
\text { on taxation and customs to study and implement } \\
\text { recommendations. } \\
\text { Regarding tax procedures, the new Tax Administration Decree } \\
\text { (effective January 2010) harmonizes and simplifies } \\
\text { administration. }\end{array}$} \\
\hline $\begin{array}{l}\text { For domestic tax administration reform, } \\
\text { review all tax procedures, especially the } \\
\text { burdensome assessment regime, and } \\
\text { develop effective business processes. }\end{array}$ & \\
\hline $\begin{array}{l}\text { For customs, develop a comprehensive } \\
\text { reform plan and review business } \\
\text { processes under the new organizational } \\
\text { proposals. }\end{array}$ & \\
\hline $\begin{array}{l}\text { Increase and unify the VAT threshold } \\
\text { and strengthen audits, given concerns } \\
\text { about fraudulent VAT refunds. }\end{array}$ & $\begin{array}{l}\text { The authorities increased the VAT threshold in the } 2010 \text { Budget } \\
\text { (from } F \$ 30,000 \text { to } F \$ 50,000 \text { for goods and from } F \$ 15,000 \text { to } \\
\text { F } \$ 50,000 \text { for services). }\end{array}$ \\
\hline
\end{tabular}




\section{Table 8. Fiji: Status of Key 2006 FSAP Recommendations}

\begin{tabular}{|c|c|}
\hline FSAP Recommendations & Status/Progress \\
\hline $\begin{array}{l}\text { Enhance supervision while } \\
\text { economizing on RBF's } \\
\text { resources. Make greater use of } \\
\text { external and financial } \\
\text { institution internal auditors. }\end{array}$ & $\begin{array}{l}\text { The RBF has made substantial progress in dealing with their staffing problems } \\
\text { and has filled all examiner and analyst positions. A challenge remains, however, } \\
\text { with high staff turnover. The RBF has made extensive use of external auditors. }\end{array}$ \\
\hline $\begin{array}{l}\text { Introduce risk-based } \\
\text { supervision to ensure that } \\
\text { supervision is focused on the } \\
\text { areas and institutions of greatest } \\
\text { concern, including matters other } \\
\text { than credit risk. }\end{array}$ & $\begin{array}{l}\text { The RBF has made good progress in implementing risk-based supervision. The } \\
\text { cycle of onsite examinations has been done on a risk-based basis with pre-exam } \\
\text { information collected based on internal discussions of significant risk areas, and } \\
\text { integrated with offsite information. In-house stress testing is currently carried out } \\
\text { on an ad-hoc basis, but the RBF is working toward regular stress testing with the } \\
\text { help of Fund technical assistance provided in March } 2009 \text {. } \\
\text { Market risks policies have yet to be developed but supervision units have started } \\
\text { examining these areas. In September, a draft Banking Supervisory Policy on } \\
\text { Minimum Requirements for Management and Operational Risk was circulated to } \\
\text { the industry for comments and will be finalized by year end. Supervisory actions } \\
\text { have been stepped up for the FNPF with recent onsite recommendations focusing } \\
\text { on strengthening corporate governance and risk management. }\end{array}$ \\
\hline $\begin{array}{l}\text { Sign MOUs with all relevant } \\
\text { foreign and domestic } \\
\text { supervisors. }\end{array}$ & $\begin{array}{l}\text { A draft MOU with the Australian Prudential Regulation Authority (APRA) has } \\
\text { not been finalized. The RBF is discussing a draft MOU with the Bank of Papua } \\
\text { New Guinea. The Capital Markets Development Authority (CMDA), an agency } \\
\text { responsible for regulating and supervising capital markets, has recently been } \\
\text { brought under the RBF. }\end{array}$ \\
\hline $\begin{array}{l}\text { Clarify the powers and } \\
\text { responsibilities of the RBF and } \\
\text { the MOF. }\end{array}$ & $\begin{array}{l}\text { A new RBF Act has been drafted bringing it into line with international standards. } \\
\text { The draft Act has been reviewed by the Fund. }\end{array}$ \\
\hline $\begin{array}{l}\text { Strengthen liquidity forecasting } \\
\text { capacity to improve forecasting } \\
\text { of foreign reserves and the net } \\
\text { position of the government, and } \\
\text { improve the RBF's ability to } \\
\text { undertake a systematic analysis } \\
\text { of the forecasting errors. }\end{array}$ & $\begin{array}{l}\text { The RBF has discussed with MOF ways to improve cash flow forecasts. The RBF } \\
\text { monitors and analyzes daily forecast errors, and produces monthly forecasts to } \\
\text { year-end. However, the use of direct control instruments and the suspension of } \\
\text { open market operations since June } 2007 \text { made the liquidity forecasting exercise } \\
\text { practically irrelevant and thus halted its improvement. }\end{array}$ \\
\hline $\begin{array}{l}\text { Improve government securities } \\
\text { primary issuance techniques } \\
\text { (auction frequency, advanced } \\
\text { calendar, benchmark issues, } \\
\text { consolidation). }\end{array}$ & $\begin{array}{l}\text { No progress has been made on this front. The government still relies heavily on } \\
\text { the FNPF to finance its deficits and sees no immediate need to implement this } \\
\text { recommendation. The CMDA intends to incorporate these recommendations into } \\
\text { its master plan for capital market development. }\end{array}$ \\
\hline $\begin{array}{l}\text { Fiji National Provident Fund } \\
\text { (FNPF) strengthening and } \\
\text { reform. }\end{array}$ & $\begin{array}{l}\text { The FNPF Board is considering the recommendations of an actuarial report } \\
\text { conducted by Mercer consultants. In addition, a paper has been drafted for } \\
\text { possible demonopolization of compulsory retirement savings. Plans are also in } \\
\text { place for a comprehensive review of the operations of the FNPF including an } \\
\text { overhaul of governance structure to ensure FNPF autonomy and long-term } \\
\text { sustainability. An expert on the Singapore's Central Provident Fund (CPF) will } \\
\text { assist the authorities in coming months. A proposed action plan should be } \\
\text { finalized by the first quarter of } 2010 \text {. }\end{array}$ \\
\hline
\end{tabular}




\section{INTERNATIONAL MONETARY FUND}

FIJI

\section{Staff Report for the 2009 Article IV Consultation-Informational Annex \\ Prepared by the Asia and Pacific Department \\ (In consultation with other departments)}

December 23, 2009

Contents

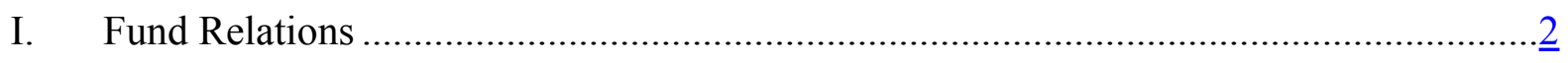

II. Relations with the World Bank Group...................................................................

III. Relations with the Pacific Financial Technical Assistance Centre ..................................

IV. Relations with the Asian Development Bank ……....................................................

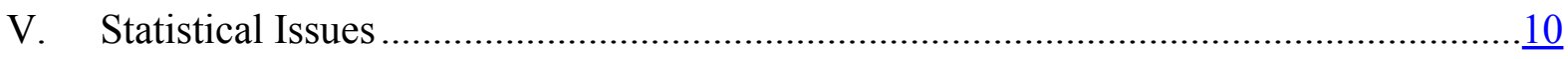




\section{Annex I: Fiji-Fund Relations}

As of November 30, 2009

I. Membership Status: Joined: May 28, 1971; Article VIII

II. General Resources Account:

SDR million

70.30

54.33

Fund holdings of currency

Reserve position in Fund

III. SDR Department:

Net cumulative allocation

Holdings
15.98

SDR million

67.09

67.06
\% Quota

100.00

77.29

22.73

\% Allocation

100.00

99.95

IV. Outstanding Purchases and Loans: None

V. Financial Arrangements: None

VI. Projected Obligations to Fund

(SDR million; based on existing use of resources and present holdings of SDRs):

\begin{tabular}{lcccc} 
& \multicolumn{4}{c}{ Forthcoming } \\
\cline { 2 - 5 } & 2010 & 2011 & 2012 & 2013 \\
\cline { 2 - 5 } Principal & & & & \\
Charges/Interest & 0.01 & 0.01 & 0.01 & 0.01 \\
$\quad$ Total & 0.01 & 0.01 & 0.01 & 0.01
\end{tabular}

\section{Exchange Rate Arrangements:}

Since April 1975, the exchange rate of the Fiji dollar has been linked to a basket of currencies of Fiji's five major trading partners: the U.S., Australian, and New Zealand dollars; the pound sterling (replaced by the Euro at the beginning of 1999); and the Japanese yen. The weights used in the basket, based mainly on the value of trade and tourist transactions are reviewed annually. The exchange rate of the Fiji dollar against U.S. dollar, the intervention currency, is determined daily by the Reserve Bank of Fiji (RBF) in relation to the currency basket. The RBF's buying and selling rates for transactions in U.S. dollars are communicated to commercial banks. On April 15, 2009, the Fiji dollar was devalued by 20 percent against the basket. The exchange rate was F\$1.9059 per U.S. dollar as of November 30, 2009.

Exchange and capital controls were tightened significantly in 2000. Some of the exchange restrictions have been eliminated and amended since then. Remaining restrictions subject to 
Article VIII arise from the Fiji Islands Revenue and Customs Authority tax certification requirements before foreign companies can remit profits abroad and from limits on large payments (e.g., oil imports and dividends).

Approval of most current payments was delegated to commercial banks and foreign exchange dealers in the late 1990s. However, the extent of delegation was tightened during periods of stress on foreign exchange reserves, most recently in April 2009. In December 2009, the RBF announced an increase in the delegated ceilings for commercial banks and foreign exchange dealers for most current payments, effective January 1, 2010. There are also quantitative restrictions in Fiji dollars on offshore portfolio and direct investments by the Fiji National Provident Fund and other nonbank financial institutions, companies, and individuals.

\section{Last Article IV Consultation}

The 2004 Article IV consultation discussions were held in Suva during May 19-June 1, 2004. The consultation (Staff Report No. 04/270 and 04/271) was completed by the Executive Board on August 23, 2004. Fiji was on a 24-month cycle with the concurrence of the authorities.

Article IV consultation missions visited Suva in December 2007 and September 2008. The consultations were not completed, however, as discussions with the authorities continued concerning the staff's view that the Fijian dollar was substantially overvalued.

\section{Technical Assistance from Headquarters}

\section{Fiscal Affairs Department (FAD):}

- $\quad$ The Report on the Observance of Standard and Codes on Fiscal Transparency for Fiji was published on March 3, 2004.

- Assistance on review of tax and customs organization and operations, March-April, 2008.

- $\quad$ Assistance on investment tax incentives, January-February, 2009.

\section{Monetary and Capital Markets Department (MCM):}

- $\quad$ Long-term policy advisor with the Reserve Bank of Fiji, July 1993-November 1996.

- $\quad$ Assistance on monetary management, money and securities markets, and foreign exchange operations, September 1994.

- $\quad$ Assistance on bank supervision and monetary management, February 1996.

- Assistance on exchange rate arrangement and capital account liberalization, November 1997. 
- $\quad$ Assistance on bank supervision, August 1998-August 1999.

- $\quad$ Assistance on insurance sector supervision, March 2002.

- $\quad$ Assistance on risk based framework for supervision of National Provident Fund and Pension funds, November-December 2005, March 2006.

- $\quad$ FSAP mission with World Bank, June-July 2006.

- $\quad$ Assistance on monetary operations and secondary market development, August 2006.

- $\quad$ Assistance on pension fund supervision, April-May 2007.

- $\quad$ Assistance on stress testing and financial stability analysis, March 2009.

- $\quad$ Comments provided from HQ on new draft Reserve Bank of Fiji Act, November 2009.

\section{Statistics Department (STA):}

- $\quad$ Assistance on Government Finance Statistics, January-February 2004.

- Monetary and Financial Statistics based on the GDDS framework, NovemberDecember 2005

- Multisector statistics advisor, 2005-2009.

- $\quad$ Balance of payments statistics, September 2006.

- Monetary and Financial Statistics under the MFS project for PFTAC members, January-February 2008.

- $\quad$ Import price index statistics, February 2008 and October-November 2008.

- $\quad$ Consumer price statistics, May 2008.

\section{Legal Department (LEG):}

- $\quad$ AML/CFT as part of Pacific project, December 2001.

- $\quad$ Assistance on Draft Financial Transactions Reporting Act, Financial Intelligence Unit and Proceeds of Crime Act, Mutual Assistance in Criminal Matters Act, November 2002-August 2004.

- $\quad$ Comments provided from HQ on new draft Reserve Bank of Fiji Act, November 2009.

X. Resident Representative: None. 


\section{Annex II: Fiji-Relations with the World Bank Group ${ }^{1}$}

(As of December 21, 2009)

Fiji became a member of the World Bank Group in 1971, and has received 13 IBRD loans totaling US\$146.4 million for projects primarily in infrastructure, telecommunications, and electric power sectors. The last IBRD loan closed in 1999, and was fully repaid by Fiji in September 2009. Since the coup in December 2006, World Bank engagement with Fiji has been guided by OP 7.30 (Dealings with De Facto Governments).

\section{Energy}

- The Bank supports Fiji's long-term goals of increasing access to electricity and shifting to renewable energy. On June 12, 2007, the Board approved US\$9.5 million provided by the Global Environment Facility for the Regional Sustainable Energy Financing Project. The project supports renewable energy electricity supplies for rural communities in Fiji and four other Pacific island countries. Of the total, US\$0.7 million is available for Fiji, and Fiji also potentially has access to $\$ 1.9$ million in regional funds available under the project.

\section{Telecoms}

- The Bank recognizes and supports government's intention to liberalize the telecoms sector, as well as enact the new legislation, as advised by the Bank, and establish an independent regulatory authority. The government successfully negotiated the termination of exclusive licenses in December 2007. It issued a Telecommunications Promulgation (new law), effective August 2008 which, inter alia, established the independent Telecommunications Authority of Fiji (TAF). The government has also issued a new mobile telecommunications license and liberalized the internet and international gateway. All these steps will in the medium-term contribute to the country's competitiveness and economic diversification.

- The Bank has also approved in principle a grant to support the new TAF, through the Institutional Development Fund. In the interim, the Bank continues to advise the government on regulatory priorities.

\section{Labor Mobility and Remittances}

- Both New Zealand and Australia have opened their borders to the short-term supply of labor from the Pacific. The Bank continues to advocate for greater labor mobility from the Pacific and is working closely with a number of PICs to remove behind-the-border constraints faced in export development. Alongside this, a strong M\&E framework has

\footnotetext{
${ }^{1}$ Prepared by World Bank staff.
} 
been established to measure the impact of greater labor mobility and to inform current and future policies.

- Remittances costs in the New Zealand-Fiji corridor were brought down from an average of 25 percent to just under 4 percent, using formal banking channels. This development was the culmination of a long process of diagnostics, dialogue, and reform led by the World Bank. New Zealand modified its domestic financial regulations to enable Westpac Bank and Visa International to launch a lost-cost remittance product in December 2008. The Reserve Bank of Fiji worked in close collaboration with World Bank officials and played a key role in opening up the remittance market to greater competition from commercial banks.

- The World Bank is now advancing similar regulatory reforms in Australia and bilateral discussions are ongoing with the Attorney General's department.

\section{Economic Assessment}

- The Bank is advising the Ministry of Social Welfare in relation to proposals to better target and strengthen Fiji's Family Assistance Program. Fiji is one of the leaders in the region in social protection. The Bank stands ready to assist these reforms, contingent on the continued commitment of the government.

- The Bank has been providing advice to the Fiji National Provident Fund (FNPF), in respect of an actuarial review of the FNPF.

\section{Investment Services}

- IFC has no active investment portfolio in Fiji, though high development impact investment opportunities engaging the private sector will continue to be considered on a case-by-case basis. IFC, along with other entities including the AsDB and EIB, is an investor in the Kula Fund II Ltd., which operates as a diversified fund investing in a variety of sectors and industries in the Pacific region-including Fiji.

\section{Disaster Risk Management}

- The Bank will be providing support, through the Pacific Islands Applied Geoscience Commission (SOPAC), to strengthen flood monitoring early warning systems in Fiji in order to mitigate future flood damage. 


\section{Annex III: Fiji-Relations with the Pacific Financial Technical Assistance Centre ${ }^{1}$}

(As of December 2009)

\section{Public Financial Management}

In March 2004, Fiji's ROSC was posted on the IMF website. PFTAC provided assistance in the development of an action plan to strengthen public expenditure management over the medium-term, which complements the authorities' financial management reform program (supported by AsDB).

Treasury operations were reviewed, with advice on the appropriate structure, functions and accounting procedures, as well as interim measures for strengthening internal controls. A peripatetic consultant assisted the government in 2006 to set up a system of Performance Budgeting, and this work was continued in 2007 and 2008 by the PFTAC PFM Advisor. A short-term mission to develop staff capacity in Debt Strategy and Sustainability Analysis was undertaken in July-August 2007. In addition, the PFTAC Advisor conducts regular monthly training courses in PFM for the staff of the Budget Division. Permanent Secretary Finance also participated in the PFTAC organized study visit to the US Treasury, in August 2008.

A Fiji participant attended the two-week PFM program in September 2009, organized by PFTAC in India. The PFM Advisor conducted a scoping study on Accrual Accounting in September 2009, following which a consultant worked, in November 2009, on the next steps to improve cash accounting, before moving toward accrual accounting.

\section{Tax Administration and Policy}

In March 2008, FAD recommended changes to FIRCAs (Fiji Islands Revenue and Customs Authority) operations, i.e., reorganize core tax and customs functions; review all tax procedures, especially the burdensome assessment regime; develop effective business processes; customs to develop a comprehensive reform plan and review business processes under the new organizational proposals; increase and unify the VAT threshold; and strengthen audits.

FIRCA have adopted all but a few of the recommendations. Terms of reference for the implementation have been finalized and steering committee and project teams formed. Following a request for technical assistance, PFTAC is discussing where it is able to assist FIRCA further.

In February 2009, Tax Policy Department evaluated the investment tax incentives of Fiji and recommended a strategy for reforming the tax incentive system and an institutional framework for tax policy making.

\footnotetext{
${ }^{1}$ The Pacific Financial Technical Assistance Centre (PFTAC) in Suva, Fiji, is a regional technical assistance institution operated by the IMF with financial support of the AsDB, Australia, Japan, and New Zealand. The Centre's aim is to build skills and institutional capacity for effective economic and financial management that can be sustained at the national level. Member countries are: Cook Islands, Federated States of Micronesia, Fiji, Kiribati, Marshall Islands, Nauru, Niue, Palau, Papua New Guinea, Samoa, Solomon Islands, Tokelau, Tonga, Tuvalu, and Vanuatu.
} 
LEG prepared a draft omnibus Administration Bill in 2006 which, excluding some discrete Customs provisions, amalgamated all revenue administrative provisions and the FIRCA Act. Following some changes the Fiji cabinet endorsed the tax administration decree in November 2009.

\section{Financial Sector Regulation and Supervision}

The PFTAC Advisor provides advice as needed to the RBF regarding financial supervision and regulation, as PFTAC is located in the RBF building. In March 2005, the Advisor provided guidance to the RBF in relation to establishing a supervisory framework for the FNPF. In November 2005, the Advisor participated in a LEG mission to strengthen Fiji's AML/CFT regime. The Advisor has provided AML/CFT training to RBF bank supervisors and in September 2007 he assisted the RBF to undertake an AML/CFT on-site examination of a bank. The Advisor has also made presentations to supervisory staff on future directions and challenges for RBF's supervisory department.

In 2008, TA in respect of supervision of the national provident fund was provided by MCM. In September 2009, RBF hosted a regional training seminar by STA on Financial Soundness Indicators and reporting requirements under the IMF Monetary and Financial Statistics Manual. In March 2009, $\mathrm{RBF}$ and PFTAC hosted a regional training seminar by MCM on Stress Testing.

\section{Monetary and Exchange Rate Policy}

In December 2009, PFTAC provided assistance to the RBF on reform of monetary policy operations and the exchange rate arrangement.

\section{Economic and Financial Statistics}

GDDS metadata for Fiji, prepared with assistance from PFTAC, are posted on the IMF website. A multi-year action plan developed in 2002 was reviewed and updated in early 2008, to strengthen both the organization and content of statistics. In response to subsequent requests by the authorities, assistance has been, and will continue to be, provided to assist the transition of balance of payments (BOP), government finance, monetary and national accounts statistics to the latest international standards, and to improve the quality of these statistics. During 2007 and early 2008 a series of missions by an STA expert focused on strengthening the monetary and financial statistics.

The PFTAC Multisector Statistics Advisor and short-term experts have undertaken nine missions during 2008 and 2009 to assist in improving balance of payments, national accounts, and prices statistics. As a result of this support, the Fiji Islands Bureau of Statistics has recently released quarterly BOP estimates and annual international investment position statistics. The coverage and quality of national accounts estimates have been significantly improved and constant price estimates have been rebased to 2005 prices.

The consumer price index has been rebased to 2005 weights, an imports' prices survey has been implemented and import price indexes are being compiled. Assistance is currently being provided to develop good quality estimates of GDP by expenditure share, quarterly GDP, and producer price indexes. 


\section{Annex IV: Fiji-Relations with the Asian Development Bank}

(As of December 18, 2009)

To date, the Asian Development Bank (AsDB) has approved 18 loans totaling \$303.6 million and, most recently, an emergency assistance loan of US\$17.5 million in August 2009 for flood damage. The Fiji government has provided sufficient counterpart funding for AsDB-financed projects. While AsDB-financed projects have not experienced significant counterpart resource constraints to date, the sustainability of the absorptive capacity of various government agencies particularly as a result of the migration of skilled staff to implement programs is a long-term concern.

The AsDB has approved 80 TA projects, totaling $\$ 27.0$ million since 1970 . There are 5 TA initiatives ongoing, including PPTAs for preparing the Renewable Power Sector Development Project and the Fourth Road Upgrading project. TAs are being implemented satisfactorily. The AsDB continues to be involved in helping to improve the policy framework in infrastructure, private sector development, and economic management.

\section{Monitoring and Evaluation}

AsDB opened a Pacific subregional office in Suva in June 2004. Generally, Fiji has complied with project loan covenants, including submission of regular progress and audit reports in the past. While there had been some delays in submission of audit reports for two projects, Suva Nausori Water and Sanitation Project and Fiji Road Upgrading Project, these are now up to date.

\section{Lending Level Proposed}

Following the military coup of December 5, 2006, AsDB's disbursements and TA operations were suspended. In April 2007, AsDB adopted a Reengagement Approach for Fiji Islands under which it was decided that "no new loan or TA processing, nor resumption of formal discussions on a new Country Partnership Strategy will take place until further guidance is received from Management." AsDB's ongoing program as set out in the Country Strategy and Program Update, 2006-08 was reactivated. Periodic reports are prepared assessing the conditions to engage in new operations under the Reengagement Approach.

When the conditions for reengagement are in place, a Country Partnership Strategy will be prepared. Possible areas for future operations include areas where there is a clear poverty alleviation focus, such as transport, power, and water and sanitation. Grant cofinancing and opportunities for commercial cofinancing and guarantees will be sought where appropriate. This will be complemented by appropriate technical assistance for project preparation, private sector enabling environment, and other areas addressing binding constraints to growth. 


\section{Annex V: Fiji-Statistical Issues}

As of December 18, 2009

\section{Assessment of Data Adequacy for Surveillance}

General: Despite significant shortcomings in some areas, especially GDP and balance of payments data, core economic and financial data provided to the Fund are generally adequate for surveillance. Macroeconomic data are slowly improving, owing in part to the considerable technical assistance provided by the Fund and PFTAC in recent years.

The Reserve Bank of Fiji (RBF) publishes the Annual Report, the Quarterly Review, and the Monthly Economic Review. The Fiji Bureau of Statistics (BoS) publishes a quarterly Current Economic Statistics and a monthly Statistical News. The Ministry of Finance and National Planning (MoF) issues the Budget Address and the Supplement to the Budget Address on an annual basis. All of these publications are received by APD on a regular basis.

Formal participation in the GDDS commenced on May 9, 2000, marked by the posting of the metadata on the IMF's Dissemination Standards Bulletin Board. The metadata were last updated in November 2002. The country has maintained its commitment to use the GDDS as a framework for statistical development.

National Accounts: Production-side estimates of GDP at current and constant prices are available up to 2008. Revised data were published in late 2009 that use the 2002 Household Income and Expenditure Survey, a new business census, and estimates of the informal sector. Expenditure-side GDP data in constant prices are not available and expenditure-side GDP data in current prices are only available through 2005. In addition, GDP broken down by income is only available through 2005.

Price statistics: The BoS is updating the CPI weights from the current 1993 base using results of the 2002 Household Expenditure and Income survey. There have been persistent difficulties in compiling export and import unit value indexes, mainly due to lack of continuity that resulted from a switch to ASYCUDA for customs processing late in 1999. The BoS plans to re-introduce trade price indexes with a starting period of 2002 (to coincide with the new benchmark year for national accounts).

Government finance statistics: Following a PFTAC supervised project, reporting of data for publication in the Government Finance Statistics (GFS) Yearbook has resumed. Data include a statement of sources and uses of cash for budgetary central government, subdivisions of receipts and payments by economic category, and outlays by function. Data for 2006 in the format of the Government Finance Statistics Manual 2001 are available. 
Some inconsistencies remain between the GFS data and fiscal data provided to APD, especially in the areas of nontax revenue, wages and salaries, other purchases of goods and services, and subsidies and transfers. Public debt data remain weak. Other problem areas include a lack of transparency in budget reporting, with some agencies outside the budget, including the Fiji Islands Revenue and Customs Authority; and an absence of published updates on the budget outcome.

Monetary statistics: Data on the monetary authorities and the deposit money banks are comprehensive and provided to APD and STA on a regular and timely basis. Data on nonbank financial institutions, including the Fiji National Provident Fund (FNPF), are less regular, timely, and reliable. With FNPF representing a large part of the financial sector, the unavailability of a consolidated financial survey hampers economic and financial analysis. The RBF is in the process of broadening its monetary survey into a depository corporations survey and compiling a financial survey that covers nonbank financial institutions. A November 2005 expert mission, during a PFTAC monetary statistics workshop, reviewed the compilation procedures and provided training and a work plan for the RBF to comply with the methodology of the Monetary and Financial Statistics Manual and to report using the standardized report forms (SRFs). A follow-up February 2008 mission provided advice on introducing the SRFs and developing an integrated monetary database that will meet the data needs of the RBF, APD, and STA.

Balance of payments: The BoS is nearing the end of a major PFTAC assisted project to compile new balance of payments data and revise historical data back to 2000 consistent with the IMF Balance of Payments Manual (fifth edition). Revised annual balance of payments data were published in late 2009 that significantly reduced errors and omissions in 2008 from over 10 percent of GDP to about 6 percent of GDP. Initial estimates of quarterly balance of payments data and the annual investment position were published in December 2009, but contain a number of weaknesses, including inconsistency of the stock and flow data. A separate project to publish data on international trade in services is also nearing completion, while technical assistance to address problems in the capital and financial accounts will start shortly. Balance of payments data for the period up to end-2006 were reported to the Statistics Department for publication in the 2007 Balance of Payments Yearbook. Problems remain in the measurement of external debt, due to the absence of a consistent framework and insufficient coordination between the RBF, the BoS, and the MoF.

\section{Data Standards and Quality}

Fiji is a GDDS participant. The statistics advisor based at PFTAC in Suva is the GDDS Project Manager for the Pacific region. 


\section{Fiji-Table of Common Indicators Required for Surveillance}

(As of December 18, 2009)

\begin{tabular}{|c|c|c|c|c|c|}
\hline & $\begin{array}{c}\text { Date of latest } \\
\text { observation }\end{array}$ & Date received & $\begin{array}{c}\text { Frequency } \\
\text { of }{ }^{5}{ }^{\text {Data }}{ }^{2}\end{array}$ & $\begin{array}{l}\text { Frequency } \\
\text { of } \\
\text { Reporting }\end{array}$ & $\begin{array}{l}\text { Frequency } \\
\text { of } \\
\text { Publication }\end{array}$ \\
\hline Exchange Rates & November 2009 & December 2009 & $\mathrm{D}$ & M & M \\
\hline $\begin{array}{l}\text { International Reserve Assets and Reserve Liabilities } \\
\text { of the Monetary Authorities } 1\end{array}$ & November 2009 & December 2009 & M & M & M \\
\hline Reserve/Base Money & November 2009 & December 2009 & M & M & M \\
\hline Broad Money & November 2009 & December 2009 & M & M & M \\
\hline Central Bank Balance Sheet & November 2009 & December 2009 & M & M & M \\
\hline Consolidated Balance Sheet of the Banking System & November 2009 & December 2009 & M & M & M \\
\hline Interest Rates ${ }^{2}$ & November 2009 & December 2009 & M & M & M \\
\hline Consumer Price Index & November 2009 & December 2009 & M & M & M \\
\hline $\begin{array}{l}\text { Revenue, Expenditure, Balance and Composition of } \\
\text { Financing }{ }^{3} \text { - General Government }\end{array}$ & 2008 & November 2009 & A & A & A \\
\hline $\begin{array}{l}\text { Revenue, Expenditure, Balance and Composition of } \\
\text { Financing }{ }^{3} \text { - Central Government }\end{array}$ & 2008 & November 2009 & A & A & A \\
\hline $\begin{array}{l}\text { Stocks of Central Government and Central } \\
\text { Government-Guaranteed Debt }\end{array}$ & Q3, 2009 & November 2009 & Q & Q & Q \\
\hline External Current Account Balance & Q1, 2009 & December 2009 & Q & A & A \\
\hline Exports and Imports of Goods and Services & 2008 & September 2009 & A & A & A \\
\hline GDP/GNP & 2008 & November 2009 & A & A & Q \\
\hline Gross External Debt & 2008 & November 2009 & A & A & A \\
\hline
\end{tabular}

\footnotetext{
${ }^{1}$ Includes reserve assets pledged or otherwise encumbered as well as net derivative positions.

${ }^{2}$ Both market-based and officially determined, including discount rates, money market rates, and rates on treasury bills, notes, and bonds.

${ }^{3}$ Foreign, domestic bank, and domestic nonbank financing.

${ }^{4}$ The general government consists of the central government (budgetary funds, extra budgetary funds, and social security funds) and state and local governments.

${ }^{5}$ Daily (D), monthly (M), quarterly (Q), and annually (A).
} 


\section{IMF Executive Board Concludes 2009 Article IV Consultation with}

\section{Fiji}

On January 11, 2010, the Executive Board of the International Monetary Fund (IMF) concluded the Article IV consultation with Fiji. ${ }^{1}$

\section{Background}

Growth has been sluggish in recent years because of delays in economic reforms, worsening terms of trade, and political developments that have strained Fiji's international relations and hurt business confidence. Fiji's economy is expected to have contracted by $2 \frac{1}{2}$ percent in 2009 , reflecting the adverse impact of the global crisis on exports and tourism. The economy was also hit by flooding in January 2009 that damaged tourism, crops, and infrastructure. As a result of slow growth, the unemployment rate rose to $8 \frac{1}{2}$ percent, and would have been higher if not for an increase in emigration.

The real effective exchange rate appreciated by 10 percent between 2000 and 2008 as the terms of trade deteriorated by 15 percent because of lower export prices for sugar and higher oil prices. The current account deficit widened from 4 percent to 18 percent of GDP over the same period, and in early 2009 , foreign exchange reserves fell to US $\$ 300$ million, less than two months of imports. In April 2009, the Reserve Bank of Fiji (RBF) devalued the currency by 20 percent and intensified exchange controls. Following

\footnotetext{
${ }^{1}$ Under Article IV of the IMF's Articles of Agreement, the IMF holds bilateral discussions with members, usually every year. A staff team visits the country, collects economic and financial information, and discusses with officials the country's economic developments and policies. On return to headquarters, the staff prepares a report, which forms the basis for discussion by the Executive Board. At the conclusion of the discussion, the Managing Director, as Chairman of the Board, summarizes the views of Executive Directors, and this summary is transmitted to the country's authorities. An explanation of any qualifiers used in summings up can be found here: http://www.imf.org/external/np/sec/misc/qualifiers.htm.
} 
the devaluation, weak economic activity and lower commodity prices helped contain inflation.

Tourist arrivals fell by almost 25 percent year-on-year in early 2009 because of the global crisis and January floods. However, tourism recovered mid-year, as the devaluation of the Fijian dollar against the Australian dollar made Fiji a more attractive destination.

Foreign exchange reserves doubled between April and November 2009, to reach US\$593 million, almost four months of imports, explained by a pickup in remittances and an improvement in the trade balance. About half of the increase was also explained by the SDR allocation (US\$93 million) and repatriation of foreign assets of the Fiji National Provident Fund (FNPF, a public pension fund). Despite high current account deficits in recent years, external debt is low at 13 percent of GDP in 2008, as deficits were financed mainly by foreign direct investment (FDI) in the tourism sector.

Recent developments have put considerable pressure on the budget. Tax revenue was hit by the fall in economic activity, with a shortfall of about 10 percent relative to the budget in the first 10 months of the year. Government restrained current spending, including by containing wage increases, and the fiscal deficit increased to about 3 percent of GDP in 2009 from near balance in 2008, in line with the budget. Central government debt is expected to rise to 53 percent of GDP by end 2009. Central government guarantees of public enterprise debt and contingent liabilities arising from poor performance of public enterprises amount to about 70 percent of GDP (excluding the public pension fund).

Bank liquidity has risen sharply in recent months to more than 13 percent of deposits as foreign exchange reserves have recovered. However, credit growth is likely to have contracted in real terms in 2009 , as banks took a cautious approach in light of heightened political and economic uncertainties. The RBF increased the statutory reserve requirement on banks from 5 percent to 7 percent of deposits to reduce excess liquidity. It has also removed bank-by-bank credit ceilings and announced the removal of ceilings on banks' lending rates and spreads by January 2010.

\section{Executive Board Assessment}

Executive Directors noted that Fiji's economic performance in recent years has been negatively affected by a difficult political situation, delayed structural reforms, natural disasters, and the global crisis. Faced with increasing budget pressures, the authorities have made commendable efforts to restrain current spending and limit the overall fiscal deficit in 2009, while the devaluation of the Fijian dollar has helped reverse the sharp decline in foreign exchange reserves. The economic situation nevertheless remains challenging, and downside risks remain high. Directors therefore stressed the need for further decisive actions to restore macroeconomic stability and implement structural reforms needed to lift growth and ensure debt sustainability over the medium-term.

Directors agreed that a substantial reduction in the fiscal deficit is necessary to ensure macroeconomic stability and stabilize public debt. While acknowledging the difficult 
economic situation, most Directors recommended a faster pace of consolidation starting from 2010 than is currently envisaged. They considered that infrastructure rebuilding needs should be offset by expenditure measures, including civil service reform, while revenue could be strengthened by rationalizing tax incentives, improving tax administration and raising excise taxes. Directors encouraged the authorities to adhere to their earlier target of reducing central government debt to 45 percent of GDP by 2014 .

Directors supported a tight monetary policy to ensure that inflation returns to low levels and to protect foreign exchange reserves. They welcomed the recent increase in the statutory reserve deposit ratio and the removal of ceilings on bank lending rates and spreads, and called for further measures as needed to absorb excess liquidity.

Directors encouraged the authorities to move toward a more flexible exchange rate. They considered that the shift to a more flexible exchange rate regime will help Fiji absorb external shocks and protect its reserve position. Directors noted that exchange rate flexibility should be accompanied by a strengthening of monetary and fiscal policies.

Directors welcomed recent improvements in bank supervision. They expressed concern about the vulnerability to adverse shocks of some smaller banks and recommended remedial action where appropriate. Directors called for fundamental reform of the FNPF. In particular, they stressed the importance of measures to put the FNPF on a sound actuarial footing, of an independent management responsible to beneficiaries, and of strengthened supervisory oversight.

Directors considered that structural reforms are crucial to ensure fiscal sustainability, address competiveness problems, lift potential growth and create jobs. They called for well-designed reforms of the civil service, of the public enterprises with a view to eventual privatization, and of the land-lease system, accompanied by price liberalization. Well-targeted measures should help address the social impact of these reforms.

Directors welcomed the authorities' intention to work closely with the Fund on the design and implementation of their economic policies. They noted that a Fund-supported program would require continued strong commitment to macroeconomic adjustment and structural reforms to address remaining vulnerabilities, close the external financing gap, and attract donor support.

Public Information Notices (PINs) form part of the IMF's efforts to promote transparency of the IMF's views and analysis of economic developments and policies. With the consent of the country (or countries) concerned, PINs are issued after Executive Board discussions of Article IV consultations with member countries, of its surveillance of developments at the regional level, of post-program monitoring, and of ex post assessments of member countries with longer-term program engagements. PINs are also issued after Executive Board discussions of general policy matters, unless otherwise decided by the Executive Board in a particular case. 
Fiji: Selected Economic and Financial Indicators: 2006-2010

\begin{tabular}{ll} 
Nominal GDP (2008): & US $\$ 3.6$ billion \\
Population (2008): & 843 thousand \\
GDP per capita (2008) & US $\$ 4,237$ \\
Quota: & SDR 70.3 million \\
\hline
\end{tabular}

$\begin{array}{lllll}2006 & 2007 & 2008 & 2009 & 2010\end{array}$

Prel. Est. Proj.

Real Sector (percent change)

Real GDP growth

Consumer prices (average)

Consumer prices (end of period)

$\begin{array}{rrrrr}1.9 & -0.5 & -0.1 & -2.5 & 2.0 \\ 2.5 & 4.8 & 7.8 & 4.0 & 5.0 \\ 3.1 & 4.3 & 6.6 & 6.7 & 3.0\end{array}$

Central government operations (percent of GDP)

Revenue and grants

$\begin{array}{lllll}26.1 & 25.4 & 24.8 & 23.1 & 23.0\end{array}$

Total expenditure

$\begin{array}{lllll}29.0 & 27.0 & 25.0 & 26.0 & 26.4\end{array}$

Overall balance

$\begin{array}{lllll}-3.0 & -1.6 & -0.2 & -2.9 & -3.5\end{array}$

Total debt outstanding

$\begin{array}{lllll}53.1 & 49.9 & 51.2 & 52.7 & 53.2\end{array}$

Money and credit (percent change)

Broad money (M2)

Credit to the private sector

Treasury bill rate (91-day) $1 /$

Commercial bank lending rate $1 /$

$\begin{array}{rrrrr}19.8 & 10.4 & -6.9 & 1.9 & 4.8 \\ 23.7 & 2.8 & 11.2 & 4.0 & 5.0 \\ 10.9 & 0.3 & 0.5 & 7.0 & \ldots \\ 7.9 & 8.5 & 7.7 & 7.6 & \ldots\end{array}$

Balance of Payments (millions of U.S. dollars)

Current account balance (In percent of GDP)

Trade balance

Exports

Imports

Tourism receipts

Foreign direct investment

Overall balance

$\begin{array}{rrrrr}-582 & -463 & -640 & -297 & -493 \\ -18.7 & -13.6 & -17.9 & -9.5 & -16.0 \\ & & - & & \\ -897 & -842 & 1,108 & -714 & -812 \\ 729 & 787 & 944 & 637 & 673 \\ 1,626 & 1,629 & 2,052 & 1,351 & 1,485 \\ 433 & 434 & 483 & 368 & 406 \\ 415 & 329 & 313 & 263 & 264 \\ 145 & 91 & -169 & 219 & -156 \\ & & & & \\ 460 & 551 & 381 & 600 & 561 \\ 2.9 & 2.7 & 2.5 & 3.9 & 3.5 \\ 445 & 461 & 449 & 378 & 517 \\ 14.4 & 13.5 & 12.6 & 12.1 & 16.9 \\ 7.8 & 7.2 & 8.4 & 7.5 & 8.3\end{array}$

Reserves and external debt (millions of U.S. dollars)

Gross official reserves

(In months of retained imports)

External debt 2/

(In percent of GDP) 2/

Central government external debt (percent of GDP)

Exchange rate

Fiji dollars per US dollar, end of period

$\operatorname{REER}(2000=100$, end period) $3 /$

$\begin{array}{lrrr}1.7 & 1.6 & 1.8 & 1.9\end{array}$

$\begin{array}{llll}106.9 & 109.9 & 114.4 & 90.2\end{array}$

Sources: Data provided by the Fijian authorities; and staff estimates and projections.

1/ For 2009, interest rates as of September.

2/ For 2010, it includes BOP support to fund a US\$120 million financing gap.

3/ For 2009, REER as of June. 


\section{Statement by Ms. Duangmanee Vongpradhip, Executive Director for Fiji}

1. On behalf of the Fiji authorities, we wish to express our gratitude and appreciation to Mr. Brooks and his team for the very fruitful and constructive discussions held during the Article IV Mission to Fiji between November 10 and 24, 2009. The mission was indeed timely and highly welcomed by the authorities, as it came at a time when Fiji as a small island economy is struggling to recover, not only from the global crisis, but also from the destructive effects of the worst floods in its history in early 2009. Fiji remains vulnerable to such natural disasters as seen by Cyclone Mick in December 2009. Our authorities recognize the support that the Fund has shown in the recent period to small island economies in the region, and specifically wish to convey their utmost appreciation to the Fund for its concern, support, and engagement with Fiji.

2. Our authorities agree with the broad thrust of the Staff Report, which has appropriately highlighted the significant economic and policy challenges facing the economy. The Report is also welcomed as it provides sound advice and useful ideas at a time when the Government of Fiji is actively formulating and implementing an ambitious package of reforms to strengthen macroeconomic stability and position the economy for growth. Indeed some of the reforms suggested by Staff had been announced in the 2010 Budget which had been scheduled shortly after the conclusion of the mission, reflecting the strong commitment and ability of the Government to expedite action. This statement thus seeks mainly to briefly highlight the current economic developments in Fiji to reinforce Staff's assessment, and elaborate on the authorities views in a few areas.

\section{Recent Economic Developments and Outlook}

3. Economic growth, which averaged 0.4 percent between $2006-2008$, is expected to have contracted by 2.5 percent in 2009 , reflecting the combined effects of the severe floods in January 2009 and the global crisis. The extensive flooding inflicted considerable damage to infrastructure, farms and livestock, schools, and properties. Human lives were lost, whilst water and electricity supply were disrupted for weeks following breakdowns to machinery and electrical equipment. The two largest sectors in Fiji, the sugar and tourism industries, bore the brunt of the impact, adding acute stress on the balance of payments position as exports declined. The cost of the devastation is estimated at around F\$113 million, equivalent to 1.9 percent of GDP. Remittances also declined sharply in the first quarter of 2009 , further slowing economic activity. The unemployment rate is estimated to have exceeded 8 percent by end-year.

4. The intense strains on the external position in the first quarter of 2009 led to foreign reserves declining to a low of US\$239 million, less than 2 months of imports. Subsequently, the Reserve Bank of Fiji (RBF) devalued the currency by 20 percent in April 2009. Restrictions on external outflows were also introduced to smooth out 
payments and moderate the impact on the reserves position. The devaluation in the exchange rate was also in line with a key recommendation of past Staff missions to facilitate external adjustment. These measures helped reverse the sharp decline in foreign reserves. Reserves reached US $\$ 568$ million by end December 2009, almost four months of imports, reinforced substantially by the SDR allocation and a turnaround in trade balance and remittance flows. Given the improvements, a number of the exchange restrictions were relaxed in November - December, with a view to eventually eliminating exchange controls.

5. In part anchored by Fiji's low and stable inflation record (inflation averaged 3.1 percent in the last decade), inflation did not rise substantially as a result of the devaluation, due also to a relatively quick and limited pass-through, weak demand conditions and muted wage developments, and lower commodity prices compared to 2008 when inflation recorded a high of 6.6 percent. From a trough of -0.3 percent in April 2009 prior to the devaluation, price increases have likely peaked at around 7 percent by end-2009, despite the recent loosening of price surveillance for a number of items, with all forms of price controls to be removed from January 2010 as announced in the 2010 Budget. Inflation is expected to decline thereafter to about 2 percent in 2010 , although further global crude oil price increases are acknowledged as a risk to the forecast.

6. For 2010, the authorities expect economic growth of 1.9 percent, close to the Staff forecast. This modest recovery would be supported in part by recovery in trading partner economies and would be driven largely by tourism and related industries, including the wholesale and retail trade and hotels and restaurants sectors. However, growth will be muted or negative in public administration and defense, education, and the health and social work sectors due to lower government spending in real terms in line with the government's commitment to consolidate the fiscal position further.

7. Nonetheless, the external position is expected to come under strain again going forward into 2010, as imports pick up in line with the economic recovery and oil prices trend higher, as well as lower transfers. The current account deficit, which narrowed from 17.7 percent of GDP in 2008 to 8.7 percent in 2009 , is expected to widen again to about 10 ( 9.2 to be precise) percent of GDP. Dividend repatriation flows, part of which had been retained in 2009, are expected to rise, and the reserves position will be further impacted by a bullet repayment of a $\$ 150$ million sovereign bond falling due in 2011 . Notwithstanding the substantial current account deficits in recent years, external debt remains low at about 13.6 percent of GDP. Nonetheless, the anticipated financing gap is of concern to the authorities. 


\section{Policy Discussions}

\section{Monetary and Exchange Rate Policy}

8. Monetary policy conducted by the RBF has focused on safeguarding foreign reserves and maintaining stable prices to create an environment conducive for growth and investment. During the early part of 2009 when liquidity was tight amidst declining foreign reserves, the RBF reduced its lending rate to banks and lowered the Statutory Reserve Deposit (SRD) ratio to inject liquidity into the system. With liquidity in the system increasing amidst subdued credit demand and higher levels of foreign reserves, the RBF raised the SRD ratio to 7 percent effective December 2009. The credit ceiling on banks that was introduced in December 2006 was removed on 1 September 2009. The ceiling on banks' lending rates and interest spread, introduced in April 2009 to increase the affordability of credit, were also removed from 1 January 2010. Specific exchange control transactions have been re-delegated to commercial banks and foreign exchange dealers with increased limits since 1 January 2010.

9. As the economy recovers, the RBF agrees with Staff on the need to further normalize monetary conditions and is keen to simplify the framework for monetary policy to increase its effectiveness. Nonetheless, in light of limited fiscal space and with monetary costs being a significant practical constraint due to the negative "carry" from low international interest rates, possibly for an extended period, changes in policy also need to balance the impact in various respects. With both inflation and credit growth expected to remain subdued, and with the portfolio flow channel typically limited in Fiji's small financial markets, the need to sharply tighten monetary policy needs careful consideration, and our authorities are weighing the different options to best achieve the desired outcomes.

10. On exchange rate policy, our authorities have shown interest in reforming the current exchange rate regime, and are actively studying the matter with technical assistance from Pacific Financial Technical Assistance Centre (PFTAC) and in consultation with MCM. They recognize that changes in the exchange rate regime have the best chance of success if implemented in a consistent way together with changes in the monetary operations framework and in coordination with fiscal policy.

\section{Financial Sector Developments}

11. As noted by Staff, progress has been made in enhancing bank supervision, including implementing a number of recommendations of the 2006 FSAP. All major banks are adequately capitalized, with good profit performance and manageable nonperforming loans. The RBF is exploring further actions to strengthen financial stability, including increased use of risk-based analysis and expanding on the granularity of 
information collected. They are also open to conduct capital-raising for banks that are shown to be vulnerable in stress tests. Efforts to increase financial inclusion by the provision of microfinance through the branch network of the banking system are also being undertaken.

12. The authorities share the concerns expressed by Staff on the Fiji National Provident Fund (FNPF) and the Government is taking action to reform the FNPF to position it for long-term sustainability. The Government has received an actuarial valuation from Mercer, and building on a previous assessment by the World Bank, intends to make changes in the Fund, including on conversion rates for pension annuities and reviewing its governance structure. The FNPF is further receiving consultancy assistance through the Singapore Economic Cooperation in applying useful experiences from Singapore's Central Provident Fund to bring reforms forward.

\section{Fiscal Policy}

13. Our authorities share the Staff's assessment on the need to consolidate the fiscal deficit further, and are broadly in agreement with the key measures to be undertaken. As Staff have noted, the fiscal authorities showed commitment to achieve the budgeted 3 percent target for 2009 by exercising expenditure restraint in the face of an unexpected 10 percent fall in revenues. This was done by withholding wage increases and successfully reducing operating budgets.

14. The Government's deficit target of 3.5 percent of GDP for 2010 reflects the need to undertake some flood-related rebuilding and infrastructure work, and sustain necessary social expenditures and support for vulnerable groups given the weakness in the domestic economy. Poverty alleviation programs are being expanded and assistance is being increasingly targeted, including for food vouchers and bus fares. On the revenue side, the Government has announced that it would raise public service fees and charges, and is further exploring a number of measures, including those proposed by Staff of streamlining tax incentives and improving tax administration. The new Tax Administration Decree came into force on January 1, 2010, which combined with the new taxpayer portal, would further increase efficiency in tax collection and operations. In the medium term, the Government aims to reduce central government debt to 50 percent of GDP by 2014, with an earlier adjustment if the opportunity arises.

\section{Structural Reforms}

15. The Government has set out a substantive agenda for reforms covering civil service reform, public enterprise reform and land reform, areas that Staff have also identified as priorities. On civil service reform, the authorities are pushing ahead to refocus on core areas of government and right-size the government further, which will 
result in substantial reductions in current expenditure over time. A comprehensive study on civil service human resource requirements will be conducted in 2010. In addition to redundancies due to reductions in the retirement age, the water, procurement, and printing services are being corporatized, which in total account for around 10 percent of the civil service workforce. Several mergers of departments have been undertaken already, including the merger of Price and Incomes Board and Department of Fair Trading with the Commerce Commission. The incorporation of the Capital Markets Development Authority into RBF operations is another example. Outsourcing of some capital and maintenance works is also being considered.

16. Reforms in public enterprises are also in the train, with a focus on the Fiji Sugar Corporation due to its large impact on the economy and substantial employment base. Measures being discussed include privatization and closure of unviable mills. The Fiji Electricity Authority is also being reviewed to strengthen its financial position.

17. Land tenure reform is a key priority of the Government's reform agenda. It is also an area that Staff and other multilateral institutions also consider as vital to raising the economic growth potential of the economy given large areas of unutilized arable land. The Government has formed a task force that will facilitate utilization of idle land for productive use. Land will be available for leases under this effort from the first quarter of 2010 .

\section{Political Developments and Governance Reforms}

18. Given the current focus on the economic challenges, the Government has publicly committed to resume parliamentary elections latest by September 2014. In preparation for this, the National Dialogue Forum, which aims to bring together broad segments of society to discuss Fiji's political future, will commence on 1 February 2010 and is being held in preparation for a constitutional forum by September 2012.

19. The Government is committed to uphold the rule of law and strengthen the judiciary. Several laws have been promulgated since October 2009, including modernizing the criminal code to reflect aspects of current practice in the region, addressing a range of offences including human trafficking, theft and fraud, and financial information offences.

\section{Engagement with the International Community}

20. The Fiji Government has sought to actively engage the international community on assistance for its wide-ranging reforms to secure sustained economic growth and poverty reduction for the people of Fiji, and is deeply grateful for the support shown so far. It has continued to engage significantly with PFTAC through a number of TAs and 
advice in a number of areas, including public financial management, tax administration and policy, financial regulation and supervision, monetary and exchange rate policy, and economic and financial statistics. A recent notable development was the obtaining of an emergency assistance loan of US\$17.5 million by the Asian Development Bank (AsDB) in August 2009, by a unanimous approval of the AsDB's Board. AsDB has also recently approved an additional supplementary loan for road and water/sewerage upgrades. AsDB and World Bank representatives also participated in several meetings of the mission team with the authorities.

21. Given the significant challenges going forward for the balance of payments position, coupled with the critical reforms needed in the economy in the period ahead, the support and assistance of development partners and multilateral institutions will be crucial. As noted by Staff, negotiations for several bilateral loans for infrastructure are currently underway. The Fiji Government has indicated its intention to request a Fund program, and looks forward to receiving the good support of the international community in undertaking the arduous task ahead of reforming the economy to bring sustained development to the people of Fiji.

\section{Conclusion}

22. The Fiji authorities are thankful to the Fund for the continuous support and policy advice provided. They wish to thank the Executive Board, the Management, and Mr. Brooks' mission team for the excellent advice and professionalism in assisting them in this challenging period. They will continue to work closely with the Fund in monitoring developments and designing and implementing macroeconomic policies that will facilitate a more stable balance of payments position in the medium-term. The authorities welcome an annual Article IV Consultation with Fiji. 